\title{
Triple Oxygen Isotope Trend Recorded by Precambrian Cherts: A Perspective from Combined Bulk and in situ Secondary Ion Probe Measurements
}

\author{
D.O. Zakharov, J. Marin-Carbonne, J. Alleon \\ Institute of Earth Sciences \\ University of Lausanne \\ Lausanne \\ 1015 Switzerland
}

david.zakharov@unil.ch, johanna.marincarbonne@unil.ch, julien.alleon@unil.ch

\author{
I.N. Bindeman \\ Department of Earth Sciences \\ University of Oregon \\ Eugene, OR 97403 \\ USA
}

bindeman@uoregon.edu

\section{INTRODUCTION}

The surface temperature of a planet is one of the key parameters that define its potential of being habitable. On Earth, the temperature regime sustained by the seawater column provided one of the necessary conditions for evolution and prosperity of life. Ancient marine chemical sediments such as cherts and carbonates offer an opportunity to reconstruct the seawater temperature throughout geologic history due to temperature-dependent fractionation of oxygen isotope ratios between the aqueous and mineral species. Pioneered by the early work on the fractionation of ${ }^{18} \mathrm{O} /{ }^{16} \mathrm{O}$ ratio between calcite and seawater (McCrea 1950; Epstein et al. 1951; Urey et al. 1951), the isotope investigations of marine carbonates paved our knowledge of the paleoclimate and advanced our understanding of the feedbacks that exists in nature, especially those that are driven by the rise in atmospheric $p \mathrm{CO}_{2}$ (Raymo and Ruddiman 1992; Veizer et al. 1999; Berner and Kothavala 2001; Royer et al. 2004; Miller et al. 2005). The isotope ratio of oxygen measured in marine foraminifera and carbonate sediments is a trusted proxy for ocean temperatures during the past $~ 50$ Myr (Imbrie et al. 1984; Berner and Kothavala 2001; Lisiecki and Raymo 2005). Older sediments, including the early Cenozoic ones (Sexton et al. 2006; Raymo et al. 2018) and especially those exposed on land, require a great deal of detailed analysis and careful treatment of uncertainties that originate from secondary processes such as late diagenesis and metamorphism that together obscure the primary signal generated in the seawater column. Siliceous sediments such as cherts, diatoms and porcelanites are also used as a powerful temperature-sensitive seawater and lacustrine record (Brandriss et al. 1998; Leng and Marshall 2004; Swann and Leng 2009). However, these, especially cherts, cannot compare to the precision offered by the carbonate record because the rock is generated during diagenesis and crystallization of microquartz from siliceous ooze sediments. Due to the conditions imposed by this diagenetic recrystallization within the sediment, which might take place several million years after the deposition, the microquartz oxygen isotope ratios do not record the seawater column temperature, where the initial silica precipitation occurred biotically or abiotically. 
However, regarding the ancient pre-Cenozoic marine record Kolodny and Epstein (1976) rightfully noted that "in spite of these limitations, it is of interest to study $\delta^{18} \mathrm{O}$ values of the cherts as a possible imperfect indication of temperature variation of the ocean floor during the Earth's history beyond the time for which there are well-preserved carbonate skeletal remains."

The key observation was made based on studies since the early 1970 's: the average ${ }^{18} \mathrm{O} /{ }^{16} \mathrm{O}$ ratio of pre-Cenozoic and older carbonates and cherts decreases at the rate of about $2 \%$ per every 500 Ma (Fig. 1; Shields and Veizer 2002; Prokoph et al. 2008; Veizer and Prokoph 2015 and references therein). The ${ }^{18} \mathrm{O} /{ }^{16} \mathrm{O}$ ratio of Archean cherts and carbonates is $10-12 \%$ lower than the average of Phanerozoic counterparts, which, expressed in $\delta^{18} \mathrm{O}$ relative to Vienna Standard Mean Oceanic Water (VSMOW), has a value of $+28 \%$ (see Fig. 1). The conventional delta notations used here are defined as $10^{3} \cdot\left[R_{\text {sample }} / R_{\text {VSMOW }}-1\right]$, where $R$ stands for isotope ratios of oxygen and hydrogen, i.e., ${ }^{18} \mathrm{O} /{ }^{16} \mathrm{O},{ }^{17} \mathrm{O} /{ }^{16} \mathrm{O}$ and $\mathrm{D} / \mathrm{H}$. This secular trend has been interpreted in three different ways: i) precipitation in the hot oceans (see Fig. 1; up to $85^{\circ} \mathrm{C}$ in Knauth and Lowe 2003; Robert and Chaussidon 2006); ii) much lower ${ }^{18} \mathrm{O} /{ }^{16} \mathrm{O}$ ratio of seawater while ocean temperature remain similar to modern (e.g., Kasting et al. 2006); iii) diagenetic obliteration of the primary signal (Degens and Epstein 1964; Ryb and Eiler 2018). A combination of these three hypotheses is also a possibility (for review refer to Jaffrés et al. (2007) and Discussion in Bindeman 20XX, this volume). The first two interpretations have very different and important implications for the secular evolution of Earth's systems during the vast majority of geologic history until about $400 \mathrm{Ma}$ (Fig. 1). Significantly higher temperature of the Precambrian oceans requires high concentrations of atmospheric green-house gases testing the extent of the 'faint young Sun paradox' (Kasting 1993; Pavlov et al. 2000; Berner and Kothavala 2001). Such explanation would be at odds with the multimillion-year-long snowball Earth glacial episodes of the Paleo- and Neoproterozoic (Hoffman et al. 1998; Kirschvink et al. 2000).

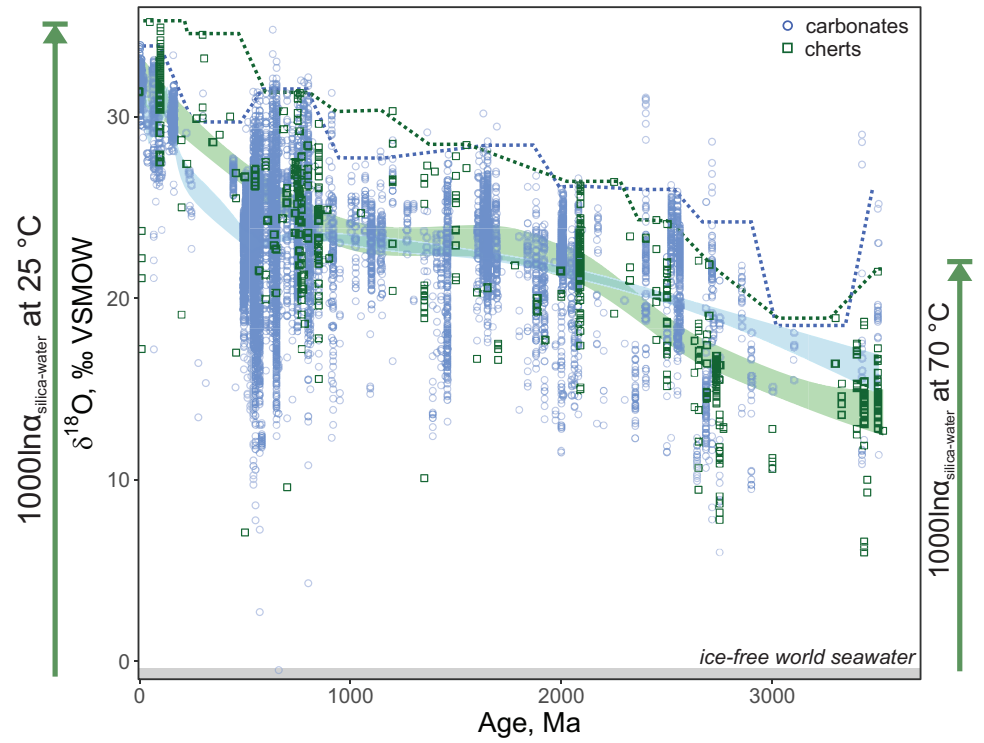

Figure 1. The oxygen isotope trend defined by carbonates (blue) and cherts (green) from Archean (to the right) to present day (at origin). The values are compiled from (Shields and Veizer 2002b; Knauth 2005; Prokoph et al. 2008). The moving averages (solid bands) are plotted using the local polynomial regression LOESS method. The dotted lines approximate the composition of least-altered samples. Drawn based on the formula: mean + upper limit of the interquartile multiplied by 1.5 , i.e., without the outliers. The temperature-dependent fractionation of $\delta^{18} \mathrm{O}$ between silica and water in equilibrium is shown on each side of the plot assuming that seawater oxygen isotope composition stayed around $-1 \%$. 
On the other hand, a significantly lower ${ }^{18} \mathrm{O} /{ }^{16} \mathrm{O}$ ratio of seawater is difficult to maintain on geologically long time scales, as spreading at mid-ocean ridges and seawater-basalt reaction produces fluids that are buffered by the oxygen isotope composition of the oceanic crust (Muehlenbachs and Clayton 1972; Holland 1984). This implies a different isotope budget of terrestrial hydrosphere in which dominant fluxes of exchanged oxygen are not controlled by high-temperature reactions with mantle-derived rocks (i.e., oceanic crust). However, previous investigations of ophiolites and Precambrian altered seafloor rocks do not provide any evidence for such conditions on the geologic timescale (Muehlenbachs and Clayton 1972; Holland 1984; Holmden and Muehlenbachs 1993; Muehlenbachs 1998; Furnes 2004; Turchyn et al. 2013; Sengupta and Pack 2018; Zakharov and Bindeman 2019).

Besides the explanations entailing significant differences in the ocean temperature or in its oxygen isotope composition, this trend might also be attributed to the secular evolution of diagenetic conditions. The recent advances in clumped carbonate measurements (Eiler 2011; Cummins et al. 2014; Watkins and Hunt 2015; Bergmann et al. 2018; Ryb and Eiler 2018) enable researchers to estimate the temperature of solid-state reordering in carbonate structure independently of the isotope ratio of equilibrium fluid, which places constraints on preservation of original temperature signals making the effect of late diagenetic recrystallization resolvable. However, there is no method like clumped isotopes that can help to resolve the extent of diagenetic obliteration of the original signal available for siliceous sediments. Yet the low $\delta^{18} \mathrm{O}$ meteoric waters and/or metamorphic overprint (Perry and Lefticariu 2003; Liljestrand et al. 2020) are also frequently invoked to explain the low ${ }^{18} \mathrm{O} /{ }^{16} \mathrm{O}$ values of Precambrian chert. The effects of diagenetic transformation of siliceous sediments have been previously demonstrated with silicon and oxygen isotope in situ measurements by secondary ion probe mass spectrometry (SIMS). Such studies (Robert and Chaussidon 2006; Marin et al. 2010; Marin-Carbonne et al. 2012; Stefurak et al. 2015; Cammack et al. 2018) highlighted the complexity of deposition and preservation of cherts through time. While diagenetic effects are undoubtedly important for biogenic and chemical precipitates, there is a potential for at least some preservation of original seawater signals. These previous in-situ-based studies suggest that the original marine signals could be recognized by a combination of methods, e.g., high-resolution measurements of isotope ratios, trace elements and non-traditional approaches such as triple oxygen and clumped isotopes.

Nonetheless, it is important to stress that the temporal oxygen isotope trend (Fig. 1) is defined not only by carbonates and cherts, but also by shales (Bindeman et al. 2016, 2018), phosphates (Karhu and Epstein 1986) and iron oxides (Galili et al. 2019), all of which show a similar first-order transition from low to high ${ }^{18} \mathrm{O} /{ }^{16} \mathrm{O}$ ratios across the geologic timescale, potentially reflecting a secular evolution of the hydrosphere. The oxygen isotope temporal trend remains significant, yet its interpretation is one of the long-lasting debates in isotope geochemistry that has not been fully reconciled.

With the advancing ability to measure triple oxygen isotope with the precision of $0.01 \%$ or better, the fractionation of two isotope ratios, ${ }^{17} \mathrm{O} /{ }^{16} \mathrm{O}$ and ${ }^{18} \mathrm{O} /{ }^{16} \mathrm{O}$, gives rise to opportunity to distinguish between process that accompany crystallization, deposition and alteration of marine sediments (Matsuhisa et al. 1978; Rumble et al. 2007; Cao and Liu 2011; Pack and Herwartz 2014; Sharp et al. 2016). The recent studies (Levin et al. 2014; Sengupta and Pack 2018; Hayles et al. 2019; Liljestrand et al. 2020) presented high-precision triple oxygen isotope measurements of cherts spanning in age from the Archean to Phanerozoic. These studies demonstrate the simultaneous change in ${ }^{17} \mathrm{O} /{ }^{16} \mathrm{O}$ and ${ }^{18} \mathrm{O} /{ }^{16} \mathrm{O}$ values of cherts across the geologic history. In theory, it could be possible to simultaneously constrain the temperature and the fluids isotope composition using the temperature dependent calibrations and the seawater evolution equations. Ambiguous conclusions about significantly different seawater composition across the geologic time scale arises in the community, mostly calling for alteration of primary signals recorded by cherts (Sengupta and Pack 2018; Liljestrand et al. 2020). 
In this chapter, we focus on understanding of the triple oxygen isotope signals recorded in ancient siliceous sediments deposited during the first two thirds of geologic history, particularly during the Archean (3.8-2.5 Ga) and the Paleoproterozoic (2.5-1.6 Ga), as we expect a possibility to reconstruct original isotope signature of marine signals provided careful investigation of diagenetic conditions and provenance. In general, the Precambrian (4-0.5 Ga) time encompasses the period of Earth's evolution, when conditions critical for sustaining complex life were established, permitting the biogeochemical cycles and biological diversification that gave our planet the modern appearance (Broecker and Broecker 1985). Below we present an overview of some emblematic Precambrian chert formations. We also provide an overview of how triple oxygen isotopes can be used to gain additional insights into origin of silica. Further, new oxygen isotope data is presented. In this study we utilized two distinct methods that operate on different scales (macro and micro) with the goal to develop a better understanding of what signals are preserved in ancient cherts and how to interpret them. The availability of published triple oxygen isotope calibrations (Sharp et al. 2016; Wostbrock et al. 2018) combined with the large fractionation between silica and water at low temperature offer a good opportunity to take a close look at the Precambrian chert record and attempt to understand the overall increase in the ${ }^{18} \mathrm{O} /{ }^{16} \mathrm{O}$ values across the geologic timescale. Furthermore, silica is a simple matrix suitable for high-precision SIMS analysis of $\delta^{18} \mathrm{O}$ with several $\mu \mathrm{m}$ resolution (Valley and Graham 1996; Kelly et al. 2007; Marin et al. 2010; Pollington et al. 2011; Cammack et al. 2018; Begue et al. 2019). The large radius SIMS is currently incapable of generating $\delta^{17} \mathrm{O}$ with the required $\pm 0.01 \%$ o precision, but a combination of bulk triple oxygen isotopes based on $\sim 1 \mathrm{mg}$ of material with high spatial resolution of SIMS analysis for $\delta^{18} \mathrm{O}$ is currently the best available avenue to investigate the role of original depositional vs secondary diagenetic signals recorded in the chert samples. We pursue this in this Chapter.

\section{PART I: PRECAMBRIAN CHERTS AS ARCHIVE OF ANCIENT SILICA CYCLE}

Chert is a common sedimentary rock that is composed mostly of silica ( $>90$ wt. \% $\mathrm{SiO}_{2}$ ), present either as opal, amorphous silica or quartz. Despite this simple chemical formula and relatively simple silica-water isotope fractionation, chert could be formed as a direct precipitate from water, or by silicification, i.e., replacement of pre-existing rock. Precambrian cherts are particularly interesting because they represent an ancient archive of marine silica cycle prior to advent of silica-secreting marine organisms such as radiolarians, sponges and diatoms (Fig. 2). On the other hand, modern seawater has very low silica content, around $0.1 \mathrm{mmol} / \mathrm{kg}$ of $\mathrm{H}_{4} \mathrm{SiO}_{4}$, that is biotically converted to opaline silica, opal-A, that is then deposited on the seafloor. After the deposition, silica undergoes a series of transitions to aggregate of cristobalite and opal (opalCT) and finally to microcrystalline quartz (Hesse 1988; Maliva and Siever 1988; Maliva et al. 1989). Voluminous chert deposits in the Precambrian document abiotic precipitation of silica from silica-saturated seawater and/or silicification reactions that occurred close to the seafloor interface (Fig. 2). The upper limit of dissolved marine silica throughout geologic history can be perhaps be taken as the point of saturation of seawater with amorphous silica that would occur at the concentration of around $3 \mathrm{mmol} / \mathrm{kg}, 22^{\circ} \mathrm{C}$ and $\mathrm{pH}$ of 7.9 (Okamoto et al. 1957), similar that of modern oceans (Siever 1992). Multiple prior studies (Knauth and Lowe 2003; Van den Boorn et al. 2007) also have highlighted the complex origin of chert, especially during the Archean. It is common to find Archean cherts as partially formed through silicification of a precursor lithology, see classification in (Van den Boorn et al. 2007). The precursors could be recognized by the relicts of carbonates, evaporitic minerals, and altered volcanic fragments imbedded into cherts, partially or completely silicified. In other cases, bedded cherts appear to be purely chemical precipitate from a seawater solution, even within the same stratigraphic context these differences are apparent (Knauth and Lowe 1978). Furthermore, unlike the 


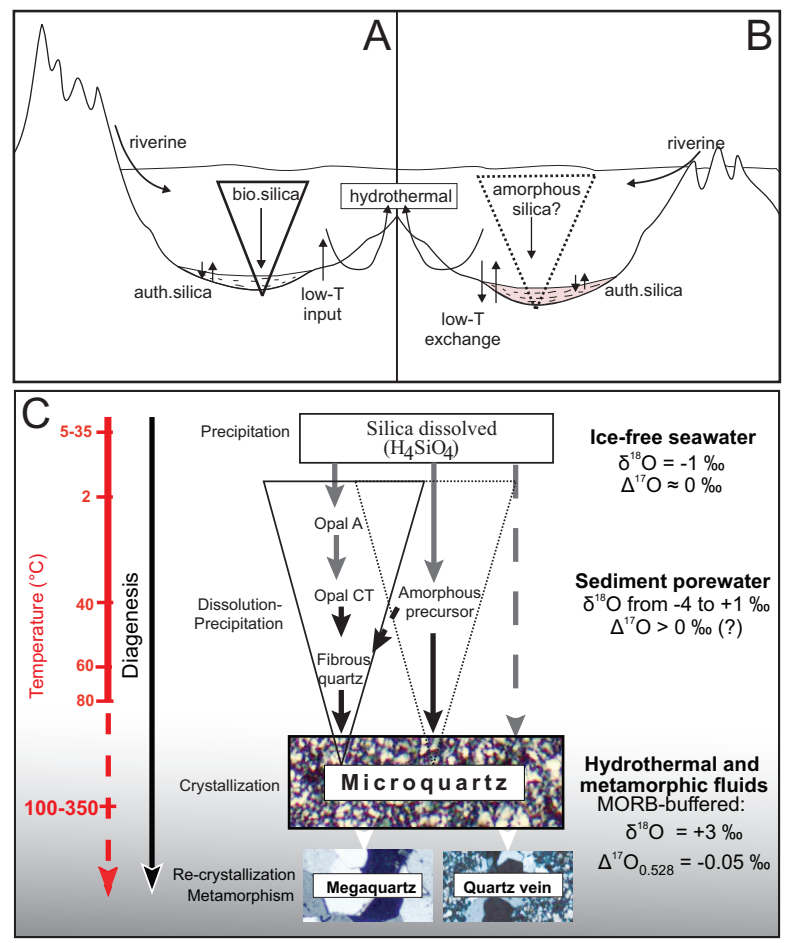

Figure 2. Schematic and simplified drawing of Phanerozoic (A) and Precambrian (B) silica cycles. The key distinction is presence of biologically mediated silica cycle in the Phanerozoic and its absence in the Precambrian. In addition, early Precambrian continents likely lacked vast subaerial exposures of continental crust available for subaerial weathering. The important fluxes of dissolved silica are riverine and hydrothermal contributions. In addition, low-temperature off axis interaction between seawater, porewaters, siliceous sediments (oozes) and mid-ocean ridge basalts also contributes to the marine silica budget. In the Precambrian, when silica-secreting critters were absent, the marine $\mathrm{H}_{4} \mathrm{SiO}_{4}$ concentration was likely higher causing abiotic precipitation of amorphous silica. The right panel depicts the deposition of opaline silica, which is accompanied by submarine diagenetic reactions between siliceous sediments and pore fluids with phase transitions to opal-A, opal-CT and crystallization of quartz. The panel $\mathbf{C}$ shows the ways to achieve precipitation and early diagenesis of modern (solid triangle) and Precambrian silica (dotted). The figure is adapted and modified from (Knauth 1994; Marin-Carbonne et al. 2013). The effects of late diagenesis, metamorphism and late hydrothermal cycling of fluids are shown with precipitation of megaquartz and quartz veins, which frequently occur in samples of Precambrian cherts. The oxygen isotope values of possible silica-saturated fluids in modern oceans are shown.

Phanerozoic chert deposits, many Archean cherts form fracture-filling, dike-like structures often interpreted as a result of hydrothermal delivery of Si induced by chemical interaction between seawater and seafloor (Knauth and Lowe 1978; Paris et al. 1985; Nijman and Valkering 1998; Hofmann and Bolhar 2007; Hofmann and Harris 2008). Vast occurrences of silicification and replacement textures (e.g., komatiite with quartz-formed spinifex texture) inform of silica influx from the submarine pore or vent fluids and by adsorption onto pre-exiting mineral surfaces (Siever 1992). Production of silica-rich fluids is commonly attributed to hydrothermal, exhalative activity caused by seawater-rock interaction at greenstone belts (Paris et al. 1985; Konhauser et al. 2001). This presents an evidence that Archean cherts formed via multiple pathways of dissolved silica from seawater to seafloor and sub-seafloor. Therefore, reconstructing oceanic paleotemperature from a silicified volcanic precursor or a hydrothermal silica deposit might not produce an accurate temperature estimate of the ocean water. 
The origin of Precambrian chert is further complicated by microtextural diversity and micrometer-scale heterogeneities. Petrographic and in situ studies have revealed that even at a micrometer scale cherts can be highly heterogeneous in oxygen and silicon isotopes, and thus have recorded multiple precipitation events (Knauth 1994; Marin-Carbonne et al. 2012; Stefurak et al. 2015; Cammack et al. 2018). Cherts frequently visibly combine multiple morphologies: microcrystalline quartz, chalcedonic, megaquartz and quartz vein (Knauth 1994). The most abundant silica phase is typically microquartz, which consist of $\alpha$-quartz crystal with size ranging between 2 to $20 \mu \mathrm{m}$, irregular boundaries and sweeping extinction (Folk and Weaver 1952; Hattori et al. 1996; Maliva et al. 2005). Microquartz and chalcedonic quartz are considered as the first silica phase formed during chert precipitation and thus the most pristine (Knauth and Lowe 1978; Knauth 1994; Marin et al. 2010). Megaquartz is composed of relatively large crystals with size greater than $20 \mu \mathrm{m}$ across with clear granoblastic textures. It forms by secondary, replacement process, as void-filling cement and also appears in heavily metamorphosed species. As chert might have experienced further post-depositional fluid circulation, quartz veins are often abundant and consist of quartz grains with sizes between 10 and $200 \mu \mathrm{m}$. Fluid inclusions trapped in such quartz indicate that veins formed as a result of fluid circulation at high temperatures, often between $150-300{ }^{\circ} \mathrm{C}$ (Harris et al. 2009; MarinCarbonne et al. 2011; Farber et al. 2015). These observations document the prolonged history of fluid cycling and quartz recrystallization that occur after the seafloor deposition of marine silica (Fig. 2). Thus, it is important to document the texturally different generations of silica phases and their isotope composition by SIMS.

\section{The collection of early Precambrian cherts}

As outlined above, it is critical to understand the petrographic and geologic context of chert samples that are used to study the isotope composition of terrestrial hydrosphere on the time scales ranging from Archean to modern days. Extending to as early as $\sim 3.8 \mathrm{Ga}$ and especially common in Archean greenstone belts, ancient cherts have been the subject of numerous studies (Perry and Tan 1972; Knauth and Epstein 1976; Knauth and Lowe 2003; Perry and Lefticariu 2003; Knauth 2005; Robert and Chaussidon 2006) that focused on the temporal trend defined by their oxygen isotope values and the implications for the global evolution of the planet. Being spatially and temporally close to Banded Iron Formations (BIFs), the Archean and Proterozoic cherts are still actively studied with the goal to understand the geochemical cycles intrinsic to the first half of the Earth's history, including the evolution of atmospheric oxygen content and its consequences on marine species (Holland 1984; Siever 1992; Canfield 1998; André et al. 2006; Poulton and Canfield 2011). Further, cherts are well known to finely preserve morphological details of fossilized microorganisms in the geological record dating back to the Paleoproterozoic eon (Javaux and Lepot 2018). Emblematic Precambrian chert formations (see Fig. 3) that have been extensively studied came from four different Archean greenstone belts and Proterozoic basins:

1. The $3.8 \mathrm{Ga}$ Isua Greenstone Belt (Ueno et al. 2002; van Zuilen et al. 2003; André et al. 2006; Whitehouse and Fedo 2007; Heck et al. 2011; Brengman et al. 2016)

2. The 3.5 - 3.4 Ga Warawoona Group from the Pilbara Craton (Knauth and Lowe 1978; Robert and Chaussidon 2006; Van den Boorn et al. 2007; Marin-Carbonne et al. 2012; Cammack et al. 2018).

3. The 3.4 - 3.3 Ga Onverwacht Group from the Barberton Greenstone Belt (Knauth and Lowe 1978; Robert and Chaussidon 2006; Abraham et al. 2011; Marin-Carbonne et al. 2011; Geilert et al. 2014; Stefurak et al. 2015).

4. The 1.9 Ga Paleoproterozoic Gunflint Formation of the Animikie group (Winter and Knauth 1992; Robert and Chaussidon 2006; Marin et al. 2010). 


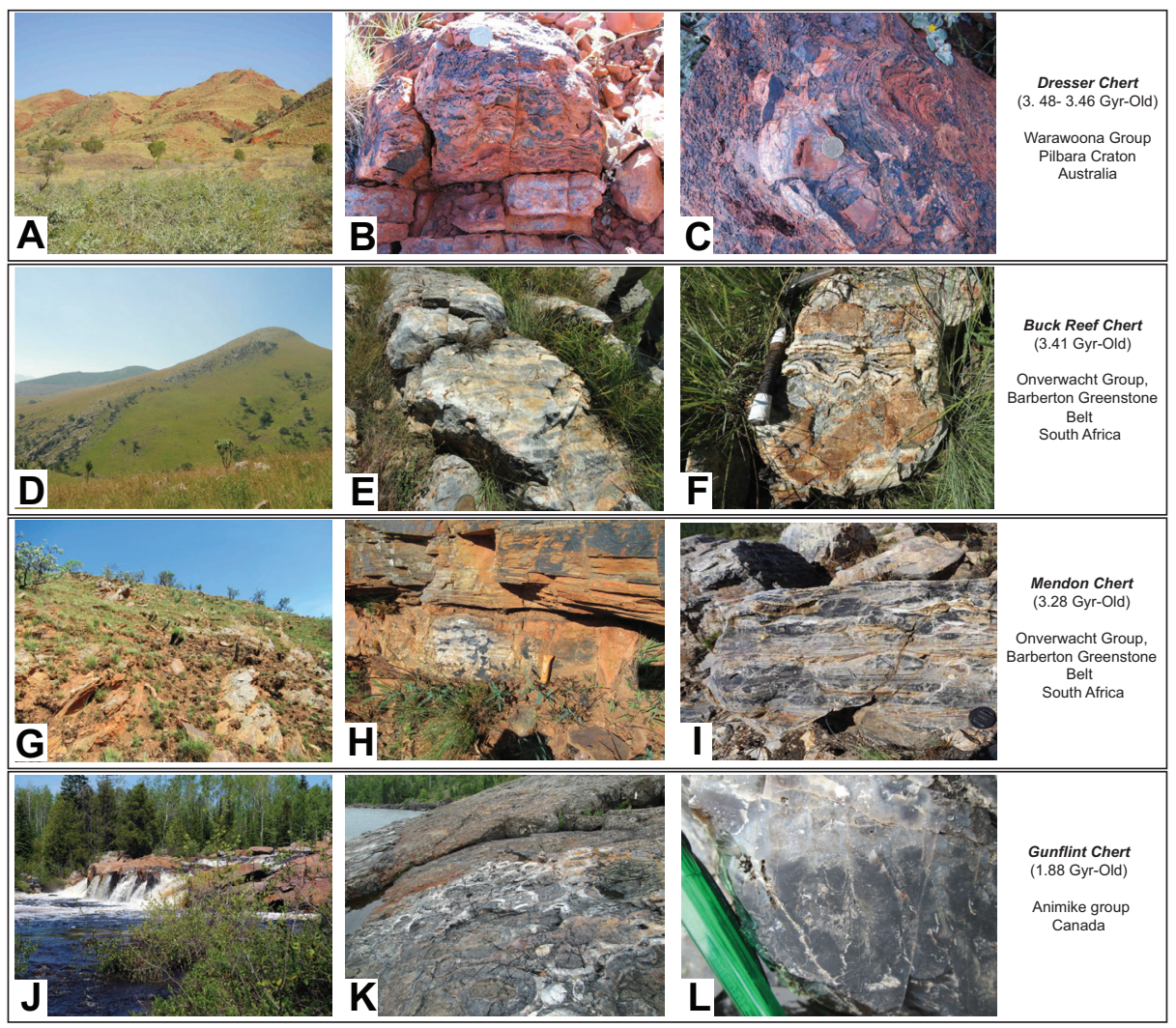

Figure 3. Emblematic Archean and Proterozoic chert formations. A - Landscape view of the Dresser Formation at the North Pole locality and the outcrops of (B) stromatolitic chert, and (C) stromatolitic and bedded cherts. D - Landscape view of the Buck Reef Chert with (E) white and black bedded chert, and (F) evaporitic chert. G - Outcrops of the Mendon chert with laminated black and white cherts $(\mathbf{H}$ and $\mathbf{I})$. $\mathbf{J}$ - Kakabeka Falls, Ontario in Canada, a locality for the Gunflint Formation. (K) Schreiber Beach locality with outcrops of stromatolitic chert. (L) A detailed view of the Schreiber Beach stromatolitic chert. Photographs are courtesy of N. Olivier, P. Sans-Jofre, C. Thomazo and R. Shapiro.

Here we will review the main characteristic of these emblematic chert formations, but we will not discuss the Isua chert as these rocks have experienced higher metamorphic grade (amphibolite facies) and have a more complex history of post depositional modifications (Dauphas et al. 2004; André et al. 2006). In this study we do not consider the chert bands associated with Banded Iron Formations (BIFs). They are also very common in the Precambrian and host large amounts of silica and iron oxides, reflecting high amounts of $\mathrm{H}_{4} \mathrm{SiO}_{4}$ and $\mathrm{Fe}^{2+}$ dissolved in ancient seawater. Although their deposition occurred in deep and calm water of the Precambrian oceans, the origin of BIFs-associated cherts deposits is often considered to be different from the bedded cherts that were deposited in shallower environments. Moreover, the BIFs silica has very low $\delta^{30} \mathrm{Si}$ (down to $-4 \%$; Chakrabarti et al. 2012) and very low $\delta^{18} \mathrm{O}$ values (down to 7\%o; Heck et al. 2011) that potentially suggest a different pathway of silica precipitation, involving hydrothermal fluids, diagenesis at high temperature, precipitation induced by temperature variation in seawater column, and/or adsorption of silica on iron oxides (Konhauser et al. 2017; Schad et al. 2019). 
The Warawoona Group (3.52-3.43 Ga, Pilbara Craton, Australia). The Warawoona Group is located in the Pilbara Craton (Western Australia) and consists of alternating volcanic units with sedimentary successions and it is well-known for the abundance of well-preserved stromatolites (Fig. 3; Allwood et al. 2006). The Strelley Pool Formation unit consists of a sedimentary succession was initially deposited between 3.43 and $3.35 \mathrm{Ga}$ in a shallow marine environment (Hickman 2008). There, seven distinct stromatolite facies (see Fig. 3) that vary within paleoenvironments of a shallow-water facies carbonate platform were described (Allwood et al. 2007). Detailed multi-scale morphological and geochemical studies of the stromatolites and organic matter have led to a broad consensus on the presence of early life in this formation (Wacey 2010; Bontognali et al. 2012; Flannery et al. 2018). The Dresser Formation (3.5 Ga) consists of an alternating succession of chert, evaporite and pillow basalt (Van Kranendonk 2006). The base unit consists of silicified carbonate. Most of the units in the Pilbara craton have experienced hydrothermal fluid circulation and metamorphism (Lowe 1983; Buick and Dunlop 1990; Hickman 2008; Wacey 2010; Sugitani et al. 2013), thus high-temperature vent fluids are suggested to be the source of the silicification of the chert. The Dresser formation has experienced extensive hydrothermal alteration in the range of $250-300^{\circ} \mathrm{C}$ that have led to crystallization of barite (Van Kranendonk et al. 2008; Harris et al. 2009). One sample from the Dresser formation, PPRG 006, has been analyzed in this study. This sample has been previously extensively studied for organic matter characterization (e.g., Binet et al. 2008) and for $\mathrm{O}$ and $\mathrm{Si}$ isotope composition (Robert and Chaussidon 2006; Marin-Carbonne et al. 2011, 2012).

Onverwacht Group (3.55-3.26 Ga, South Africa). The Onverwacht Group (Fig. 3) is the oldest unit of the Barberton Greenstone Belt in the Kaapvaal craton and consists of a sequence of ultramafic and volcanic rocks alternating with sedimentary chert layers (Lowe and Byerly 1999). The Onverwacht includes several chert layers: Sandspruit, Theespruit, Komati, Hooggenoeg, Kromberg and Mendon Formations. Cherts from the Onverwacht Group have various proposed origin, from silicified volcanic rock, like the Middle Marker chert (Lanier and Lowe 1982), hydrothermal exhalative products (de Wit et al. 1982; Hofmann and Harris 2008) to marine chemical sediment (Knauth and Lowe 1978; Tice and Lowe 2006). Bulk O and $\mathrm{Si}$ isotope studies on 3 different volcanic chert successions from the Onverwacht Group have also suggested that cherts were late stage silicified rocks formed from the alteration of basalt (Abraham et al. 2011). Further $\mathrm{O}$ and $\mathrm{Si}$ isotope studies on the Buck Reef chert of the Kromberg Formation have reported stratigraphic changes and support a marine origin for this chert (Hren et al. 2009; Geilert et al. 2014; Stefurak et al. 2015). The Buck Reef chert (3.416 Ga; Fig. 3) consist of the largest accumulation of pure and carbonaceous silica deposits of the Archean rock record (Kruener et al. 1991; Lowe and Byerly 1999; de Vries et al. 2010). As some authors have found no evidence for hydrothermal activity (Tice and Lowe 2004), others have proposed that part of the Buck Reef chert was silicified during late hydrothermal circulation (Hofmann and Bolhar 2007; Hofmann and Harris 2008). One of the samples (PPRG 193) in current study came from a black band in the Buck Reef chert of the Kromberg Formation.

Mendon Formation (3.34-3.26 Ga) is also a part of the Onverwacht group (Fig. 3) and it is characterized by $50-75 \mathrm{~m}$ of black, black and white and ferruginous chert (Lowe and Byerly 1999; Trower and Lowe 2016) and was deposited by slow sedimentation in a quiet water settings during a period of local volcanic quiescence (Stefurak et al. 2014). Previous studies have highlighted the influence of post depositional fluid circulations, especially on $\mathrm{S}$ and $\mathrm{Fe}$ isotope compositions (Busigny et al. 2017; Marin-Carbonne et al. 2020) and the metamorphic overprint likely occurred at $300^{\circ} \mathrm{C}$ (Lowe and Byerly 1999). Extensive study of $\mathrm{O}$ and $\mathrm{Si}$ isotope ratios in some Mendon chert samples have revealed $\mathrm{Si}$ isotope variations on micrometer scale (Stefurak et al. 2015) and a systematic texture-specific $\delta^{30} \mathrm{Si}$ differences, while there is no obvious correlation between the chert texture and $\delta^{18} \mathrm{O}$ values measured in the same area. This study proposes that the bulk Si isotope ratios are likely preserved but cannot be used as a robust quantitative paleothermometer due to occurrence of inter-sediment fractionations distributed 
across multiple diagenetic silica phases. A previous study that combined fluid inclusion thermometry and $\mathrm{O}-\mathrm{Si}$ isotope measurements by ion probe (Marin-Carbonne et al. 2011) also found heterogenous compositions and potentially identified multiple sources of silicon. Further, a detailed petrographic observation of the Mendon chert from the drillcore BARB4 have led the authors to propose a new mode of silica deposition as granules (Stefurak et al. 2014). Three samples (PPRG 198, PPRG 200 and Onverwacht 2 of 16.09.65) have been previously studied for oxygen and silicon isotope composition (Robert and Chaussidon 2006, Marin-Carbonne et al. 2011, 2012) and are used in this study for triple oxygen isotope analysis. Despite the preservation of sedimentological features in some of the Barberton Belt cherts, it is important to keep in mind that all of the units of the Onverwacht Group underwent metamorphism under greenschist facies conditions at temperatures around $300-350{ }^{\circ} \mathrm{C}$. Numerous intrusions were emplaced during and after the deposition of the Onverwacht Group of the Barberton Belt (de Ronde and de Wit 1994; Lowe 1994) and promoted elevated geothermal gradient, episodes of contact metamorphism and fluid circulation (e.g., de Ronde et al. 1994), all of which affected to some extent the preservation of original marine signals.

Gunflint cherts (1.88 Ga, Canada). The Gunflint Iron Formation (Fig. 3) is the middle unit of the Animikie group of Northwestern Ontario and is conformably overlain by the Rove Formation (Floran and Papike 1978). The stratigraphy of the Gunflint Iron formation was previously described by several authors (e.g., Goodwin 1956; Simonson 1987), who defined several members and lithofacies. Winter and Knauth (1992) defined five facies: banded, arenite, algal cherts and shale; they correspond to different depositional environment from deep to shallow water environment. According to these studies, the Gunflint chert have been deposited in seawater with no evidence for a mixing between seawater and local precipitation (Carrigan and Cameron 1991; Winter and Knauth 1992). The Gunflint Formation has experienced late hydrothermal circulation and metamorphism due to the Penokean Orogeney (40 Myr after the deposition of the Gunflint) and from the Duluth intrusion $(1.1 \mathrm{Ga})$. These events induced maturation of organic matter and isotope re-equilibration between constituent minerals of the nearby Biwabik Iron Formation of the same Animikie group (Hyslop et al. 2008; Marin et al. 2010), yet the Gunflint Formation remained relatively well-preserved with temperature of metamorphism under $200^{\circ} \mathrm{C}$ (Alleon et al. 2016). The 5 chert samples that have experienced different diagenetic temperatures have been selected from the Precambrian Paleobiology Research Group (PPRG 1,289 Schreiber Beach and PPRG 1,284 Frustration Bay) and from the collection of Stanley Awramick (3 of 06/30/84, 5 of 06/28/84 and 1c of 06/29/84). The samples studied here have already been previously investigates in great detail by Marin et al. (2010), Alleon et al. (2016) and Marin-Carbonne et al. (2012).

The chert of the Gunflint Formation occupies a special place in Precambrian paleontology. The discovery in the 1950s and 1960s of fossils of microorganisms in the Gunflint cherts (Tyler and Barghoorn 1954; Barghoorn and Tyler 1965), coupled with the geochronological analysis of ash-hosted zircons (1878 $\pm 2 \mathrm{Ma}$; Fralick et al. 2002), changed the way scientists view the earliest records of life on Earth (Knoll 1992). Morphologically distinct filamentous and spheroidal microfossils were described in the Gunflint cherts, and interpreted to be the remains of oxygenic photosynthetic bacteria (cyanobacteria), sulfate reducing bacteria, iron-mineralizing microorganisms, and heterotrophs (Barghoorn and Tyler 1965; Cloud et al. 1965; Awramik and Barghoorn 1977; Strother and Tobin 1987; Lepot et al. 2017). Carbon isotopic compositions of fossils identified as Huroniospora and Gunflintia minuta species were reported to be consistent with oxygenic photosynthesis (House et al. 2000; Williford et al. 2013), although anoxygenic photosynthesis, chemoautotrophy, or heterotrophy were also considered as plausible metabolisms (Lepot et al. 2017). The excellent state of preservation and the diversity of fossilized forms in the Gunflint cherts have led to a universal agreement on their authenticity, and they were thus frequently used as a reference for evaluating the origin of organic microstructures in Archean rocks (Schopf et al. 2002; Wacey et al. 2012; Brasier et al. 2015; Alleon et al. 2018). 


\section{Silica precipitation and diagenesis, and the effect of oxygen isotopes}

Our understanding of sedimentary chert genesis have little evolved since the early work in the 1970s (Knauth and Epstein 1975; Murata et al. 1977; Hesse 1988; Maliva and Siever 1988; Maliva et al. 1989, 2005; Matheney and Knauth 1993; Knauth 1994). Transfer of marine oxygen isotope signature starts with growth of skeletal silica, frustule in diatoms, at seawater-column temperatures. After diatoms die, the frustules are deposited on the seafloor to form siliceous ooze. This then undergoes a series transitions at bottom-water and subseafloor temperatures: from opaline frusta, to opal-A and opal-CT, to cristobalite and finally to microquartz. These transitions are accompanied by dissolution-precipitation and by the interaction between the siliceous sediment and pore fluids at the temperatures from 20 to $80^{\circ} \mathrm{C}$. The timing of the transitions is then governed by the burial rates and local geothermal gradient (Kolodny and Epstein 1976; Hesse 1988; Behl et al. 1994; Geilert et al. 2014). Even in marine cores recovered from Tertiary and Cretaceous sediments that have never undergone high-temperature metamorphism and were never exposed to the low $\delta^{18} \mathrm{O}$ meteoric waters intrinsic to subaerial environment, the phase transitions from amorphous precursor to microquartz are accompanied by several\%o shifts in $\delta^{18} \mathrm{O}$ (Knauth and Epstein 1975; Tatzel et al. 2015; Yanchilina et al. 2020). The shifts of around 15\% were documented by Yanchilina et al. (2020). The wellstudied Miocene chert from Monterey Shale formation is a key locality showing the evolution of oxygen isotope ratios also varying 10\%o across these phase transitions (Murata et al. 1977). Moreover, about $8 \%$ fractionation of $\delta^{18} \mathrm{O}$ values is documented in diatom frustules between antemortem and post-mortem transitions (Dodd et al. 2012). These variations are best explained by step-wise maturation of the sediment that starts at sediment-water interface and continues deep within the sediment at the local diagenetic conditions.

As cherts contain 1-2 wt. \% water in form of hydroxyl group bonded with atoms of silicon, their $\delta \mathrm{D}$ values have been used as an additional constrain for temperature and fluid sources (Knauth and Epstein 1975). Interaction of cherts with diagenetic and meteoric fluids then can be documented from coupled oxygen and hydrogen isotope analysis. The $\delta^{18} \mathrm{O}-\delta \mathrm{D}$ relationship measured in Phanerozoic formations exposed on land presents an illustrative example of meteoric water influencing the composition of chert (Knauth and Epstein 1976). Moreover, combined $\delta^{18} \mathrm{O}-\delta \mathrm{D}$ spatial profiling of a Jurassic chert nodule reveled antiphase multiple-\%o variability across the distance of $10-20 \mathrm{~mm}$ emphasizing the role of temperature during diagenesis (Sharp et al. 2002). Thus, the crystallized microquartz does not reflect equilibrium with pristine seawater in a straightforward way. A logical question arises: how can one still use cherts across the geological history if the diagenetic processes produce up to $10 \%$ o shifts in $\delta^{18} \mathrm{O}$ ?

As described above, modern chert formation is initiated by precipitation of amorphous silica, its early transformation to opal-A and opal-CT (Hesse 1988, 1989). In case of Precambrian, so far there is no evidence for precipitation as amorphous silica or as opal-CT, thus the isotope effect of these transitions is not well-established for ancient cherts. The likely precursor of Archean chert is amorphous silica gel, either precipitated directly from seawater or within the seafloor lithologies (Fig. 3). Following the pattern of modern amorphous silica, the Precambrian silica gels were likely then totally dissolved and recrystallized during diagenesis into microquartz (Winter and Knauth 1992; Knauth 1994). Logically, it is likely that the dissolution-precipitation of amorphous silica gel during diagenesis also induced modification of the oxygen isotope composition of quartz, similar to the Phanerozoic silica deposits (Kolodny and Epstein 1976; Murata et al. 1977; Jones and Knauth 1979; Knauth 1979).

A potential for isotope integrity of marine signals in Precambrian cherts is highlighted by several microscale studies that collected oxygen isotope compositions measured from 10 to $20 \mu \mathrm{m}$ pits by SIMS (Fig. 4; Marin et al. 2010; Marin-Carbonne et al. 2011, 2012, 2013; 


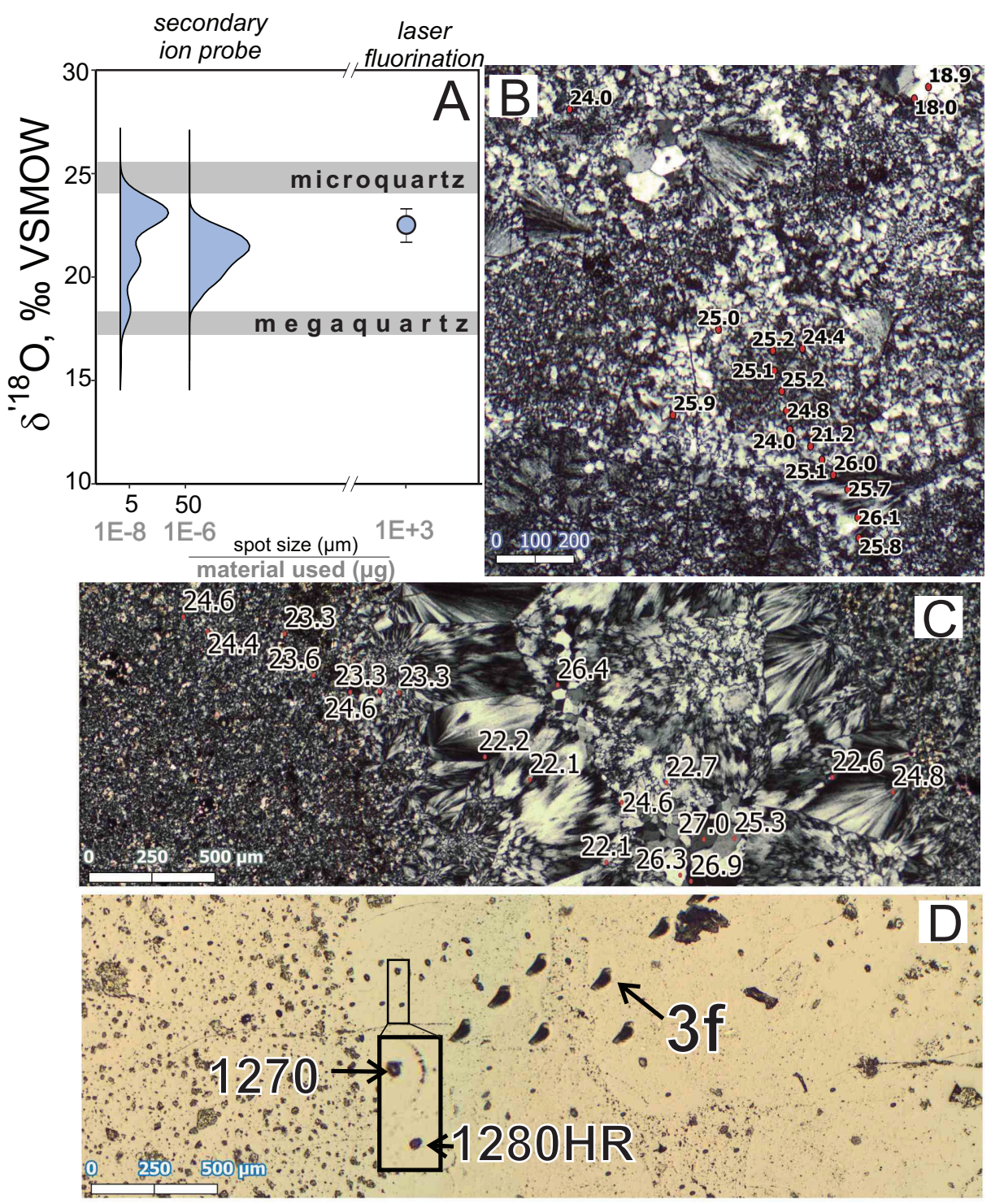

Figure 4. A - the effect of sample size on the $\delta^{\prime 18} \mathrm{O}$ values determined by secondary ion probe (SIMS; left) and by bulk laser fluorination GS-IRMS (right side). Depending on the spot size and the scale of heterogeneity, the SIMS analysis is capable of documenting isotopically diverse generations of quartz present in chert samples. The spot sizes of primary beam 5 and $50 \mu \mathrm{m}$ are used to illustrate the difference; more important is the size of the beam relative to the scale of heterogeneity. The curves are probability density functions representing random sampling of a population with dominantly high $\delta^{18} \mathrm{O}$ values $(24-25 \%$ o and a smaller population with values $17-18 \%$ ( (shown with grey bands). The bulk value determined by traditional GS-IRMS would present a very tight distribution centered around the mean value. $\mathbf{B}$ and $\mathbf{C}-$ Microscale determinations of oxygen isotope ratios by SIMS in a sample from the Gunflint Formation (Schreiber Beach) across multiple petrographic varieties. The $\delta^{18} \mathrm{O}$ values are marked in $\%$ o VSMOW next to the analyzed pits (red dots; scaled with size about $20 \mu \mathrm{m}$ ). The composition with $\delta^{18} \mathrm{O}=+24 \%$ is considered as the closest to the primary microquartz. D - reflected light image of the exact same area depicted in C. This sample was previously analyzed by Cameca ion probes 3f, 1270 at CRPG-CNRS (Nancy, France), and, the most recently, by $1280 \mathrm{HR}$ at the SwissSIMS facility (University of Lausanne). The arrows point to the pits left by the primary ion beam during the analysis by the respective ion probes. 
Cunningham et al. 2012; Stefurak et al. 2015; Cammack et al. 2018). These studies recognized multiple generations of quartz spanning a range of $\delta^{18} \mathrm{O}$ values, up to $14 \%$ within some samples. These samples are mounted within epoxy as pieces of chert several $\mathrm{cm}$ across, along with smaller grains of standards placed in the middle of the mount. The heterogeneous compositions are present on the scale of 10-100 $\mu \mathrm{m}$ and are sometimes accompanied by variations in trace element concentrations and cathodoluminescence textures but often not visible otherwise. This observation somewhat undermines the utility of the measurements done by conventional gassource isotope ratio mass spectrometers (GS-IRMS) as such analyses involve bulk liberation of $\mathrm{O}_{2}$ from 1-2 mg samples. A combination of texturally controlled triple oxygen with SIMS measurements holds some promise that is explored below.

\section{Triple oxygen isotopes in silica}

The previously proposed interpretations of the ${ }^{18} \mathrm{O} /{ }^{16} \mathrm{O}$ trend (Fig. 1), be it higher temperature of oceans, lower $\delta^{18} \mathrm{O}$ of seawater or diagenetic overprint, are not mutually exclusive due to the inability to uniquely reconstruct both fluid sources and temperature from a single isotope ratio. Adding a second isotope ratio, ${ }^{17} \mathrm{O} /{ }^{16} \mathrm{O}$, provides new opportunities. Here we focus on our new and the recently published triple oxygen isotope datasets of Precambrian cherts (Fig. 5) in the context of their microscale heterogeneities recorded by SIMS. Other isotope systems, such as hydrogen or silicon, could be used as an additional control on the nature of oxygen isotope fractionation (e.g., Robert and Chaussidon 2006; Hren et al. 2009). However, these systems might be decoupled from each other, given that silicon isotopes appear to display large fractionations controlled by precipitation mechanisms and rates (Geilert et al. 2014, 2015) and hydrogen isotopes are easily reset at low temperatures (Wenner and Taylor 1973; Knauth and Epstein 1976; Kolodny and Epstein 1976; Kyser and Kerrich 1991). In the more recent years, the triple oxygen isotope ratios ${ }^{17} \mathrm{O} /{ }^{16} \mathrm{O}$ and ${ }^{18} \mathrm{O} /{ }^{16} \mathrm{O}$ have been used to gain new insights into geologic processes, including temperature-dependent fractionation between fluids and minerals as well fluid source fingerprinting (Levin et al. 2014; Pack and Herwartz 2014; Passey et al. 2014; Herwartz et al. 2015; Sharp et al. 2016, 2018; Zakharov et al. 2017, 2019a,b; Bindeman et al. 2018; Wostbrock et al. 2018; Zakharov and Bindeman 2019; Peters et al. 2020a,b).

The slope of silica-water fractionation in the triple oxygen isotope coordinates is now calibrated and varies with temperature. For example, at temperature range from 25 to $400^{\circ} \mathrm{C}$, the slope of silica-water equilibrium fractionation varies from 0.5244 to 0.5278 (Fig. 5; Sharp et al. 2016; Wostbrock et al. 2018). This slope is expressed in $\delta^{\prime 17} \mathrm{O}-\delta^{\prime 18} \mathrm{O}$ coordinates, where each axis is a linearized notation of conventionally defined delta values, i.e., $\delta^{17718} \mathrm{O} \% o=10^{3} \cdot \ln \left(1+\delta^{17 / 18} \mathrm{O} / 10^{3}\right)$. The $\delta^{\prime 17} \mathrm{O}$-excess, expressed as $\Delta^{\prime 17} \mathrm{O}=\delta^{\prime 17} \mathrm{O}-0.528 \cdot \delta^{\prime 18} \mathrm{O}$, is a convenient way to demonstrate the offset between a point and a reference line with the slope of 0.528 in the triple oxygen isotope coordinates. That means that for a given fluid composition, the value of $\Delta^{\prime 17} \mathrm{O}_{\text {quartz }}-\Delta^{\prime 17} \mathrm{O}_{\text {water }}$ would be small at high temperatures, approaching the slope of 0.528 . At infinitely high temperature, equilibrium fractionation in the triple oxygen isotope system approaches the slope of 0.5305 (Matsuhisa et al. 1978). Since the analytical uncertainty on the $\Delta^{\prime 17} \mathrm{O}$ values is about $5-10 \mathrm{ppm}(0.005-0.010 \%$ ), equilibrium quartz and fluids would have indistinguishable values at temperatures above about $400{ }^{\circ} \mathrm{C}$, while the $\delta^{18} \mathrm{O}_{\text {quartz }}-\delta^{18} \mathrm{O}_{\text {water }}$ is $+4.5 \%$. At temperatures below $40^{\circ} \mathrm{C}$, the $\delta^{\prime 18} \mathrm{O}$ and $\Delta^{\prime 17} \mathrm{O}$ of quartz are at least $32.5 \%$ higher and $0.1 \%$ o lower than that of equilibrium fluid, respectively, as shown with the isotope composition of diatoms and sponge spiculas (Pack and Herwartz 2014; Sharp et al. 2016).

In theory, having two isotope ratios, ${ }^{17} \mathrm{O} /{ }^{16} \mathrm{O}$ and ${ }^{18} \mathrm{O} /{ }^{16} \mathrm{O}$, it is possible to solve for two unknowns, i.e., equilibrium fluids composition and temperature. In such case, the equations could be evolution of marine pore fluids, or meteoric water array, and silica-water equilibrium fractionation. While the latter has been calibrated (Sharp et al. 2016) and the meteoric 

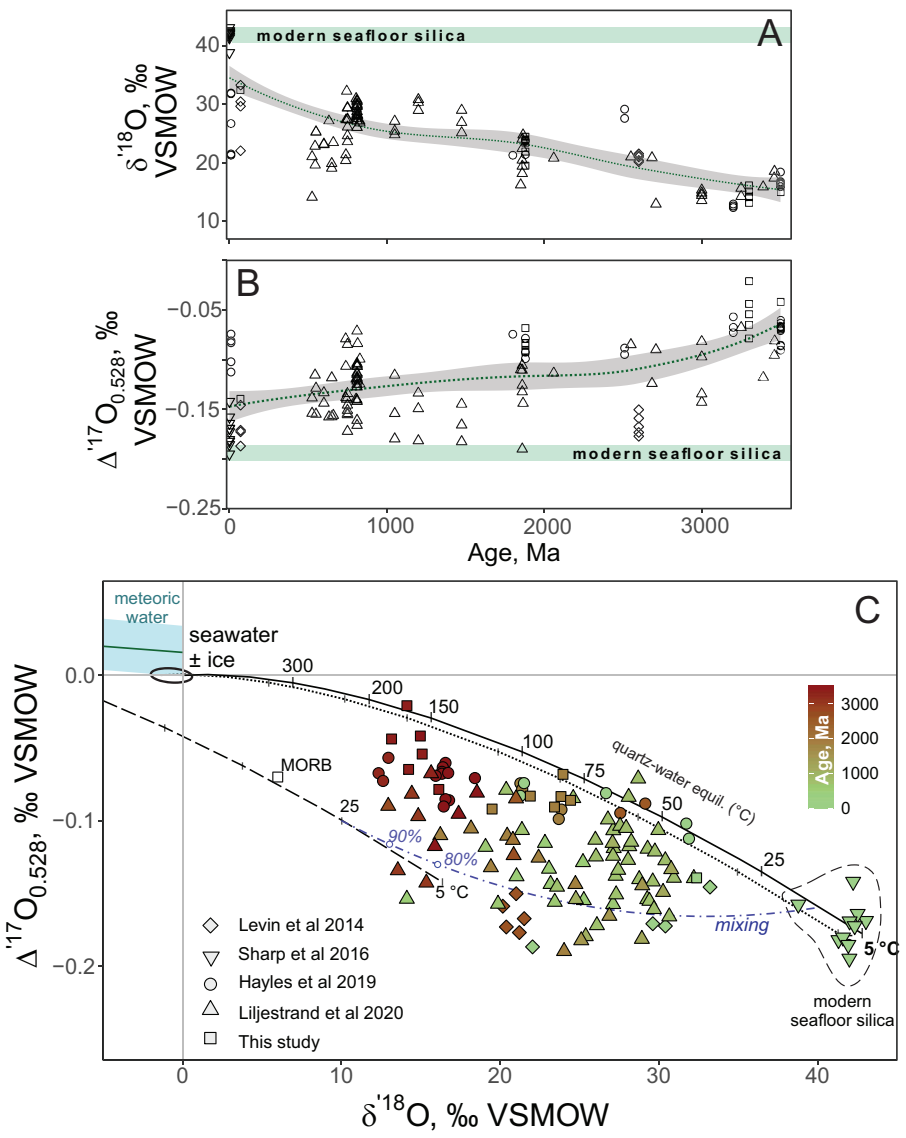

Figure 5. Triple oxygen isotope data on cherts compiled from previous studies (Levin et al. 2014; Hayles et al. 2019; Liljestrand et al. 2020) and from this study recalibrated to a common silicate standard UWG-2 (Sharp and Wostbrock 20XX, this volume). The data from (Levin et al. 2014) was recalibrated using the two-point scheme using the UWG-2 and NBS28 standards. The panel A presents the same general trend in the triple oxygen isotope dataset as in the previous conventional ${ }^{18} \mathrm{O} /{ }^{16} \mathrm{O}$ analyses (see Figure 1). The accompanied $\Delta^{\prime 17} \mathrm{O}$ values are shown in $(\mathbf{B})$. Panel $\mathbf{C}$ shows the $\delta^{\prime 18} \mathrm{O}-\Delta^{\prime 17} \mathrm{O}$ values of cherts color coded by their age including modern oceanic diatomaceous silica and one chert sample from (Sharp et al. 2016). The solid curved line shows the isotope composition of quartz in equilibrium with modern seawater. The thin curved line shows silica-water fractionation at the same temperature range but in equilibrium with ice-free seawater. The dashed line to the left shows equilibrium fractionation with meteoric water $\left(\delta^{\prime 18} \mathrm{O}=-18 \%\right.$ o $)$. Calibration after (Sharp et al. 2016). An arbitrary selection of equilibrium temperatures (5 through 300) is shown with numbers in ${ }^{\circ} \mathrm{C}$. As an example of mixed compositions, we show mixing between cherts in equilibrium with seawater and meteoric water with a blue dash dotted curve and percent of meteorically derived component is indicated. The region of meteoric waters is shown in the left upper corner after analyses presented in (Luz and Barkan 2010; Li et al. 2015; Surma et al. 2018; Passey and Ji 2019; Tian et al. 2019). The composition of mid-ocean ridge basalt (MORB) is shown with an open square.

waters were characterized in detail (Landais et al. 2008; Luz and Barkan 2010; Passey and Ji 2019; Tian et al. 2019), the exact effect of diagenesis is not known and there is no published analyses of marine pore fluids analyzed that we are aware of. The early measurements of cherts were presented by Levin et al. (2014), including some Archean and Cenozoic samples. In more recent years, silica-water equilibrium fractionation has been constrained by measurements of modern marine diatoms and geothermal silica (Sharp et al. 2016; Wostbrock et al. 2018) as well as by 
theoretical determination of fractionation factors (Cao and Liu 2011; Hayles et al. 2018). These studied provide grounds to explore the triple oxygen isotope record of terrestrial hydrosphere and diagenetic conditions recorded by cherts. One can expect that Precambrian cherts would reflect, at least partially, the original marine signals as well as the late diagenetic and metamorphic signals, thus, resulting in mixture of equilibrium compositions. The recent studies (Hayles et al. 2019; Liljestrand et al. 2020) presented high-precision triple oxygen isotope measurements of cherts spanning in age from the Archean to the Cenozoic (see Fig. 5). These papers demonstrated that the Archean cherts are $15-20 \%$ o lower in $\delta^{\prime 18} \mathrm{O}$ and about $0.1 \%$ o higher in $\Delta^{\prime 17} \mathrm{O}$ than those of the Phanerozoic age (Fig. 5). The effect of higher temperature of the Archean seawater or during diagenesis cannot be easily ruled out because the data do not follow tightly the silicawater fractionation curve. Instead, cherts plot as a 'cloud' under the curve (see Fig. 5). Such compositions could be reconciled by mixing arrays between primary and secondary silica. These arrays are curved and concave upward in the $\delta^{\prime 18} \mathrm{O}-\Delta^{\prime 17} \mathrm{O}$ coordinates. Combined with a probabilistic treatment of diagenetic effects, the study by Liljestrand et al. (2020) showed that the triple oxygen isotope values of cherts is possible to explain by recrystallization, emphasizing the $\delta^{\prime 18} \mathrm{O}$ value of seawater did not have to change significantly to replicate the entire dataset.

In essence, mixing between primary and secondary signals generated at different temperatures results in masking the original equilibrium signal. Meteoric water as the source of fluids responsible for low $\delta^{\prime 18} \mathrm{O}$ values of the ancient silica deposits has been suggested numerous times previously (Degens and Epstein 1964; Knauth and Epstein 1976; Robert and Chaussidon 2006; Tartèse et al. 2018). The triple oxygen isotope fractionation during hydrologic cycle (Luz and Barkan 2010; Li et al. 2015) is now sufficiently characterized resulting in a quasilinear relationship for $\delta^{\prime 18} \mathrm{O}-\Delta^{\prime 17} \mathrm{O}$ values, similar to the meteoric line in conventional $\delta^{18} \mathrm{O}-\delta \mathrm{D}$ coordinates (Craig 1961). Moreover, multiple stages of diagenesis and metamorphism in theory would not permit using this treatment of ancient samples to reconstruct the composition of single reservoir, such as ancient seawater-derived fluids. In this paper we take the triple oxygen isotope study of cherts one step further by attempting to resolve the influence of primary signal and diagenetic overprint on a case-by-case basis. First, we describe the in situ techniques such as secondary ion probe and Raman spectroscopy that we combine to get a detailed insight into the complexity of isotope signatures recorded by the same set of samples.

\section{Secondary ion mass spectrometry}

Secondary Ion Mass Spectrometry (SIMS) has been extensively used to determine oxygen and silicon isotope compositions at high spatial resolutions (McKeegan 1987; Hervig et al. 1992; Valley and Graham 1996; Bindeman and Valley 2001; Peck et al. 2001; Kelly et al. 2007; Bindeman et al. 2008; Eiler 2011). Since the development of large ion microprobe (series 1270-1300 from Cameca for example), it has been possible to measure oxygen and silicon isotopes with high precision : $0.2 \%$ and $0.4 \% \circ(2 \sigma)$ for oxygen and silicon isotope respectively (Kita et al. 2009; Whitehouse and Nemchin 2009), and therefore SIMS have been applied to various research questions: igneous processes (e.g., Eiler et al. 1997; Gurenko and Chaussidon 2002; Appleby et al. 2008), paleotemperature reconstruction from foraminifera and coral (for example, Rollion-Bard et al. 2003; Kozdon et al. 2018), fluid-rock interactions during metamorphism (Valley and Graham 1996; for recent examples see, Bonamici et al. 2014; Bégué et al. 2019) and biogeochemical cycles (Alexandre et al. 2015). The pioneer study of Robert and Chaussidon (2006) have measured both O and Si isotope by SIMS on a set of chert samples spanning from Phanerozoic to the Archean and highlighted a secular correlation between $\mathrm{O}$ and $\mathrm{Si}$ isotope composition. That study used a large number of cherts but performed only few measurements per sample ( 3 to 5 depending on the samples) and used the average value for the interpretation of the secular trend. Marin et al. (2010), and Heck et 
al. (2011) followed the analytical procedure described by Robert and Chaussidon (2006) with more than 400 analyses in various chert samples from Archean to Proterozoic and observed extreme isotopic variability at microscale for oxygen and silicon (see Fig. 5).

While it is possible to measure triple oxygen isotope ratios by SIMS (Tartèse et al. 2018; Bellucci et al. 2020), the applications of it remain within the realm of meteoritics, where the $\Delta^{\prime 17} \mathrm{O}$ signals are large, spanning over $1 \%$ (e.g., Krot et al. 2010). Due to the relatively large uncertainties $\left( \pm 0.2 \%\right.$ ) in ${ }^{17} \mathrm{O} /{ }^{16} \mathrm{O}$ measured by SIMS, meaningful measurements of terrestrial materials are limited. The required precision of $\pm 0.01 \%$ is achieved by the traditional gassource isotope ratio mass spectrometers like MAT 253 used here, yet the spatial resolution is compromised by the relatively large sample size of $1-2 \mathrm{mg}$ (several $\mathrm{mm}$ across), compared to several nanograms analyzed by SIMS (see Fig. 5).

\section{Raman spectroscopy}

Further insight into cherts post-depositional history can be provided by Raman spectroscopy. Raman microspectroscopy is a nondestructive spatially resolved technique that yields combined chemical and structural information on both inorganic and organic phases at the micrometer scale, and is therefore widely used in Earth sciences (Dubessy et al. 2012). As Precambrian cherts are almost exclusively made of quartz, they generally lack mineral assemblages that can be used for mineral thermometry. Yet, these rocks usually contain carbonaceous matter that has been often characterized using Raman spectroscopy in order to inform on its thermal history (Tice et al. 2004; Schopf and Kudryavtsev 2005; Wacey et al. 2012; Sugitani et al. 2013; Alleon et al. 2016, 2019).

Raman spectral features of carbonaceous matter were indeed shown to evolve systematically with metamorphic grade (Wopenka and Pasteris 1993; Yui et al. 1996). Over geological timescales, the structural evolution of carbonaceous matter is essentially governed by the maximum temperature reached during metamorphism (Beyssac et al. 2002, 2004). By studying carbonaceous matter in rocks with well-constrained $P-T$ history, Beyssac et al. (2002) first quantified a phenomenological relation between Raman spectral characteristics and peak metamorphic temperature in the range $330-650^{\circ} \mathrm{C}$. The authors decomposed the Raman signal into four different $\mathrm{G}$ and $\mathrm{D}$ bands using a pseudo-Voigt function. In lower temperature contexts $\left(200-300^{\circ} \mathrm{C}\right)$, Raman spectra are more complex and additional bands are used to describe the signal and estimate the peak temperature conditions that carbonaceous matter experienced (Rahl et al. 2005; Lahfid et al. 2010). Figure 6 illustrates the impact of increasing metamorphic temperature on the Raman spectra of carbonaceous matter preserved in Precambrian cherts studied here.

In the present study, we use Raman spectroscopy for the formations studied here by SIMS and by laser fluorination GS-IRMS for triple oxygen isotopes. To estimate the upper limit for the temperature of secondary dissolution-reprecipitation of quartz we utilized samples from the Gunflint Formation (Alleon et al. 2016), Dresser Formation (Delarue et al. 2016), and the newly collected chert samples of the Mendon Formation (Fig. 6). Raman data indicate that Gunflint organic matter experienced maximum burial temperature conditions between 160 and $220^{\circ} \mathrm{C}$ without a clear petrographic evidence for recrystallization of microquartz at this temperature (see Alleon et al. 2016a for details). Consequently, Gunflint microquartz likely recrystallized from silica precursor at temperature below, at temperatures ranging from 130 to $170^{\circ} \mathrm{C}$ as proposed previously (Marin et al. 2010). On the other hand, Archean organic matter from Dresser and Mendon Formations experienced higher peak temperature during metamorphism (Fig. 6). Recrystallization of quartz in Dresser and Mendon cherts could be bracketed by the range $300-360^{\circ} \mathrm{C}$, according to Raman spectral characteristics of carbonaceous matter. 


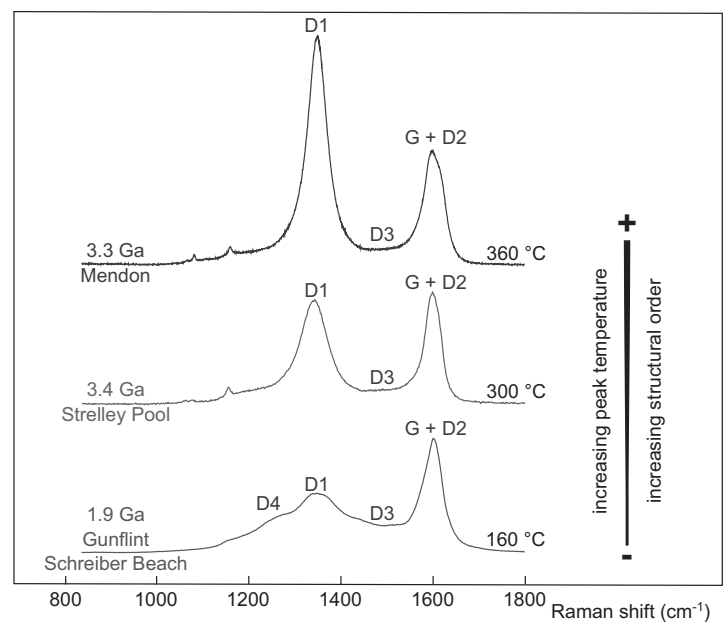

Figure 6. Evolution of Raman spectra of Precambrian organic matter with increasing metamorphic grade. Raman data and estimated peak temperatures for Gunflint and Strelley Pool organics are from Alleon et al. (2016) and Alleon et al. (2018), respectively. Raman data for Mendon organics were acquired for the present study. Estimation of the peak temperature was done following the methodology described by (Kouketsu et al. 2014).

\section{PART II: COMBINED SIMS AND TRIPLE OXYGEN ISOTOPE ANALYSIS OF PRECAMBRIAN CHERTS}

We use a unique collection of Precambrian cherts from Dresser, Mendon and Gunflint formations, 3.5, 3.2 and $1.9 \mathrm{Ga}$, respectively, that were previously characterized in great detail by in situ SIMS measurements of $\mathrm{O}$ and $\mathrm{Si}$ isotopes, and trace elemental (Al, Ti, Fe, K) concentrations (Marin et al. 2010; Marin-Carbonne et al. 2011, 2012, 2013). With the detailed spatial data set (see Figure 7), we attempt to 'see-through' the effects of provenance, secondary processes such as early and late diagenetic and metamorphic transformations that together define the triple oxygen isotope composition. At first, the procedure involves identification of the low-Al and low-Ti compositions and their $\delta^{18} \mathrm{O}$ and $\delta^{30} \mathrm{Si}$ values from the SIMS data set. This subset of data is interpreted as the earliest low-temperature generation of silica, textually identifiable as microquartz of early diagenetic origin. We then find the corresponding $\delta^{\prime 18} \mathrm{O}-\Delta^{\prime 17} \mathrm{O}$ compositions of this generation. Further, we resolve the triple oxygen isotope composition of secondary quartz generations that resulted from post-depositional dissolution and reprecipitation induced by burial and regional metamorphism.

In addition, to test for the hydrothermal origin of Archean silica (Perry and Lefticariu 2003; Van den Boorn et al. 2007), we provide triple oxygen isotope measurements of modern amorphous silica that precipitated in a geothermal pipelines at Reykjanes system of Iceland at temperatures of $180-190^{\circ} \mathrm{C}$ (Hardardottir 2011). A similar work was also done by Wostbrock et al. (2018) in a different Icelandic geothermal system with the goal to calibrate the silica-water fractionation. In Reykjanes, seawater-dominated fluid reacts with basalt at high temperature $\left(350^{\circ} \mathrm{C}\right)$. Upon depressurization and boiling of the fluid during geothermal exploration, abundant amorphous silica precipitates as scales on the walls of the pipes at lower temperature of $188^{\circ} \mathrm{C}$ (Hardardottir 2011). The silica scale was sampled from the well $\mathrm{RN}-9$. This temperature regime and shallow water conditions are commonly envisioned for the Archean silica-generating environment (De Ronde et al. 1997; Perry and Lefticariu 2003; Van den Boorn et al. 2007). Consequently, we compare the modern-day amorphous silica scale from Reykjanes to the reconstructed composition of primary silica represented by the Dresser and Mendon formation samples, where input of hydrothermal silica might have been high. 

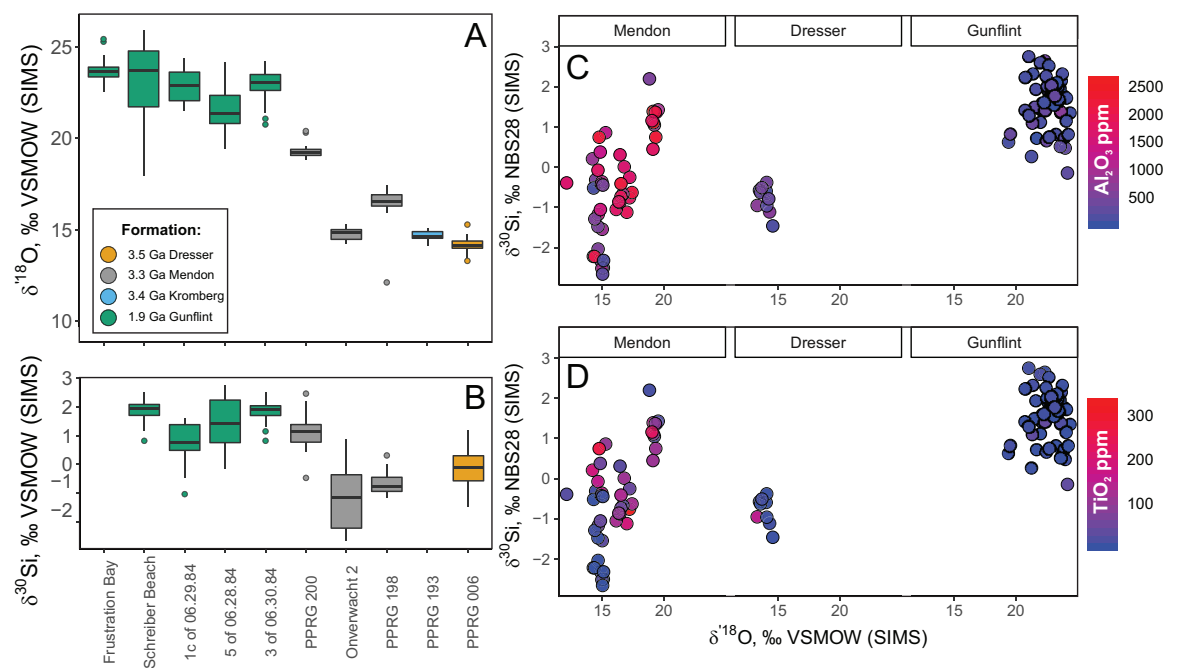

Figure 7. The inventory of oxygen (A) and silicon (B) isotope data determined by secondary ion spectroscopy (SIMS) in the samples used for triple oxygen isotope analyses. The trace elemental concentrations were measured from the same pits also by SIMS. Aluminum $\left(\mathrm{as}_{2} \mathrm{Al}_{3}\right)$ and titanium $\left(\mathrm{TiO}_{2}\right)$ concentrations are shown as color-coded points plotted against their $\mathrm{O}$ and $\mathrm{Si}$ isotope ratios $(\mathbf{C}$ and $\mathbf{D})$ and were incorporated here from the previous study (Marin-Carbonne et al. 2012).

Finally, we provide new hydrogen isotope and water content data for the same set of samples. We explore the relationship between the reconstructed triple oxygen and hydrogen isotope compositions as hydroxyl groups contained in microcrystalline quartz can be reflective of the secondary equilibrium fluids originating during different stages of diagenetic transformation of silica. In modern microquartz collected from the seafloor, hydrogen isotope compositions reflect temperature-dependent fractionation with interstitial porewaters being the likely equilibrium fluid (Knauth and Epstein 1975). However, in older counterparts of Cenozoic age, the hydrogen isotope composition of microquartz exhibit interaction with meteoric water, forming an array of values parallel to the meteoric water line (Craig 1961). Given that a similar meteoric water line exists for triple oxygen isotopes (e.g., Luz and Barkan 2010), its correlation with $\delta \mathrm{D}$ values would help to disentangle the effect of post-depositional alteration from the original marine signal.

\section{Methods}

Triple oxygen isotope measurements. The triple oxygen and hydrogen isotope analyses were carried out at the University of Oregon Stable Isotope Lab. The methodology was previously described in (Zakharov et al. 2019b). Briefly, small chips of chert (1.5-2 mg) excluding visible quartz veins were placed in a stainless-steel holder inside an oven at $130^{\circ} \mathrm{C}$ held under vacuum of a roughing pump for several hours. Later they were placed in a stainlesssteel vacuum chamber and pre-treated with $\mathrm{BrF5}$ overnight to remove the absorbed moisture and reactive compounds. After laser-assisted fluorination of samples, the extracted oxygen was purified from fluorination byproducts by a series of cryogenic traps and reaction with $\mathrm{Hg}$-vapor in a mercury diffusion pump. Then oxygen gas was trapped on a $5 \AA$ molecular sieve by cooling to liquid nitrogen temperature. The released $\mathrm{O}_{2}$ was carried though a GC-column by He-flow at the rate $30 \mathrm{~mL} /$ minute and room temperature. After about 3 minutes of elution time, the $\mathrm{O}_{2}$ was trapped on another $5 \AA$ molecular sieve at liquid nitrogen temperature. The gas was further trapped on another, smaller volume $5 \AA$ A molecular sieve immersed in liquid nitrogen and introduced into a MAT 253 gas-source isotope-ratio mass spectrometer (GS-IRMS) at $50-60^{\circ} \mathrm{C}$. Each measurement consisted of 40 cycles of sample-reference gas comparisons with intermittent equilibration of pressure in the bellows of the mass spectrometer. 
In the study we used the previously characterized silica standards (Miller et al. 2020; Wostbrock et al. 2020) to monitor the accuracy of triple oxygen isotope measurements. Four UWG-2 garnet and two San Carlos (SCO) olivine measurements were made during the analytical session between 24.09.2020 and 27.09.2020. The mean value of the measured standards yielded (mean \pm 1 standard deviation): $\delta^{17} \mathrm{O}_{\mathrm{UWG}-2}=3.137 \pm 0.073$, $\delta^{18} \mathrm{O}_{\mathrm{UWG}-2}=6.109 \pm 0.159 \%$ o, and $\delta^{17} \mathrm{O}_{\mathrm{SCO}}=2.911 \pm 0.032, \quad \delta^{18} \mathrm{O}_{\mathrm{SCO}}=5.684 \pm 0.052 \%$. In addition, we ran a chert standard SKFS (Stevns Klint Flint Standard; Miller et al. 2020) that returned $\delta^{17} \mathrm{O}_{\mathrm{SKFS}}=17.300 \pm 0.012 \%, \delta^{18} \mathrm{O}_{\mathrm{SKFS}}=33.333 \pm 0.003 \%$ reported as mean \pm standard error for a single measurement. We used the UWG-2 and SKFS values presented in, this volume from to calibrate the measurements to the VSMOW-SLAP scale $\left(\delta^{17} \mathrm{O}_{\mathrm{UWG}-2}=2.94\right.$, $\delta^{18} \mathrm{O}_{\mathrm{UWG}-2}=5.7$ and $\delta^{17} \mathrm{O}_{\mathrm{SKFS}}=17.57, \delta^{18} \mathrm{O}_{\mathrm{SKFS}}=33.81$; see Sharp and Wostbrock 20XX, this volume). The two-point calibration is used to address the instrument-specific non-linearity of the scale. However, for the point of comparison with other datasets, where SKFS was not included, most figures in this chapter present values relative to UWG-2. So far no significant scale compression/stretching was found by analyses of SCO, UWG-2 and SKFS in other laboratories (Miller et al. 2020; Sharp and Wostbrock 20XX, this volume).

Hydrogen isotopes. Hydrogen isotopes were analyzed at the University of Oregon using a high temperature thermal conversion elemental analyzer (TC/EA) connected to the MAT 253 in a continuous flow mode, where gases from samples and standards are transported in He carrier gas (Sharp et al. 2001; see recent application, Hudak and Bindeman 2020). Each solid sample and standard were wrapped in a silver foil capsule and dried in the vacuum oven overnight, then transported to the auto sampler where they were purged with He carrier gas. Two datasets were produced for hydrogen isotopes using different amount of chert analyte. First session included between 3-4 mg of chert in each capsule and second dataset included 7-9 mg of chert. To test for homogeneity, we ran the same cherts but different pieces. In the TC/EA's furnace lined with a glassy carbon column, samples underwent pyrolysis at $1450{ }^{\circ} \mathrm{C}$, and all of the $\mathrm{H}_{2} \mathrm{O}$ in the minerals was pyrolyzed to $\mathrm{H}_{2}$ and $\mathrm{CO}$ gas. Extracted gas was carried by He into a gas chromatograph and further introduced into the mass spectrometer via the CONFLOIII device. Mica standards, USGS57 and USGS58 $(\delta \mathrm{D}=-91$ and $-28 \%$, respectively, (Qi et al. 2017) were included in each analytical session to monitor the accuracy of analysis and to normalize data to VSMOW scale.

SIMS measurements of $\boldsymbol{O}$ and Si isotopes. The oxygen and silicon isotopic compositions of the two chert samples from the Gunflint Formation (Schreiber Beach and Frustration Bay) and one Archean sample PPRG 193 from the Kromberg formation (oxygen only) were determined using the Cameca IMS 1270 ion microprobe at UCLA (Los Angeles, USA) and the Cameca 1280 HR (SwissSIMS, Lausanne, Switzerland; oxygen only) during 3 different sessions, using classical procedures previously described (Marin-Carbonne et al. 2012). A meticulous microscopic observation has been carried out in all the samples in order to select the purest microquartz area, free of any visible oxides and carbonates. Oxygen and silicon isotopic compositions are reported here as per mil deviations from the international standards: VSMOW (Vienna Standard Mean Ocean Water) for oxygen and NBS28 for silicon using the delta notation.

In each mount, in-house quartz standards QZCRWU $\left(\delta^{18} \mathrm{O}=+24.5 \%\right.$; Marin 2009), and UNIL-Q1 $\left(\delta^{18} \mathrm{O}=+9.8 \%\right.$; Seitz et al. 2017) were embedded in epoxy together with the fragments of cherts. The fragments were sputtered with a $\mathrm{Cs}^{+}$primary beam of $2-25 \mathrm{nA}$ intensity, $10 \mathrm{kV}$ acceleration voltage and of size ranging from 10 to $30 \mu \mathrm{m}$ for oxygen and silicon isotopic measurements, respectively. The electron gun was used for charge compensation. Negative secondary ions were accelerated at $10 \mathrm{kV}$. The mass resolving power was set at $\sim 4000$. The ions ${ }^{16} \mathrm{O}^{-},{ }^{18} \mathrm{O}^{-},{ }^{28} \mathrm{Si}^{-}$and ${ }^{30} \mathrm{Si}^{-}$were detected in multicollection mode using faraday cups; L'2 trolley for ${ }^{16} \mathrm{O}^{-}$and ${ }^{28} \mathrm{Si}^{-}$(using a $10^{10} \Omega$ resistor) and $\mathrm{H} 1$ trolley for ${ }^{18} \mathrm{O}^{-}$and ${ }^{30} \mathrm{Si}^{-}$(using a $10^{11} \Omega$ resistor). The centering of the secondary beam in the field diaphragm and of the magnetic field 
were done automatically during the analyses. A pre-sputtering time of one minute was added for the silicon isotope measurements. With such conditions, a counting statistic $\leq \pm 0.1 \%$ o is obtained after few minutes counting (40 cycles of $5 \mathrm{~s}$ acquisition time and $60 \mathrm{~s}$ of pre-sputtering). The external reproducibility for oxygen and silicon isotopes measurements obtained on the QZCRWU and UNIL-Q1 quartz during the three sessions of analyses was \pm 0.2 and $\pm 0.4 \%$ o at one sigma.

Raman spectroscopy. Raman data were obtained using a Horiba Jobin Yvon LabRAM 800 HR spectrometer (University of Lausanne, Switzerland) in a confocal configuration equipped with an $\mathrm{Ar}^{+}$laser $(532 \mathrm{~nm})$ excitation source and a CCD detector. Raman microspectroscopy measurements were performed at constant room temperature, directly on freshly exposed surfaces of chert samples, to characterize the degree of structural organization of carbonaceous matter. The laser beam was focused on the sample with a $300 \mu \mathrm{m}$ confocal hole using a long working distance $\times 50$ objective $(\mathrm{NA}=0.70$ ). This configuration provided $\mathrm{a} \approx 2 \mu \mathrm{m}$ spot size for a laser power delivered at the sample surface below $1 \mathrm{~mW}$, thereby preventing irreversible laser-induced thermal damage. The collected Raman spectra were used to estimate the peak metamorphic temperature experienced by organic matter, following the methodology proposed by Kouketsu et al. (2014).

\section{Results}

Oxygen isotope values. In Figure 8, we compare the bulk isotope values plotted against the average values of $\delta^{18} \mathrm{O}$ determined by SIMS as well as the $\delta^{30} \mathrm{Si}$. In Figure 9, the triple oxygen isotope values are shown in the $\delta^{\prime 18} \mathrm{O}-\Delta^{\prime 17} \mathrm{O}$ coordinates with reference slope of 0.528 , along with the samples of amorphous silica scale from Reykjanes. The Archean Mendon and Dresser formation cherts have $\delta^{\prime 18} \mathrm{O}$ values between 14 and $16 \%$ consistent with the previous values reported by SIMS in the exact same samples. Their $\Delta^{\prime 17} \mathrm{O}$ values cluster at $-0.05 \pm 0.02 \%$ o (Fig. 9). The early Paleoproterozoic cherts of the Gunflint formation have
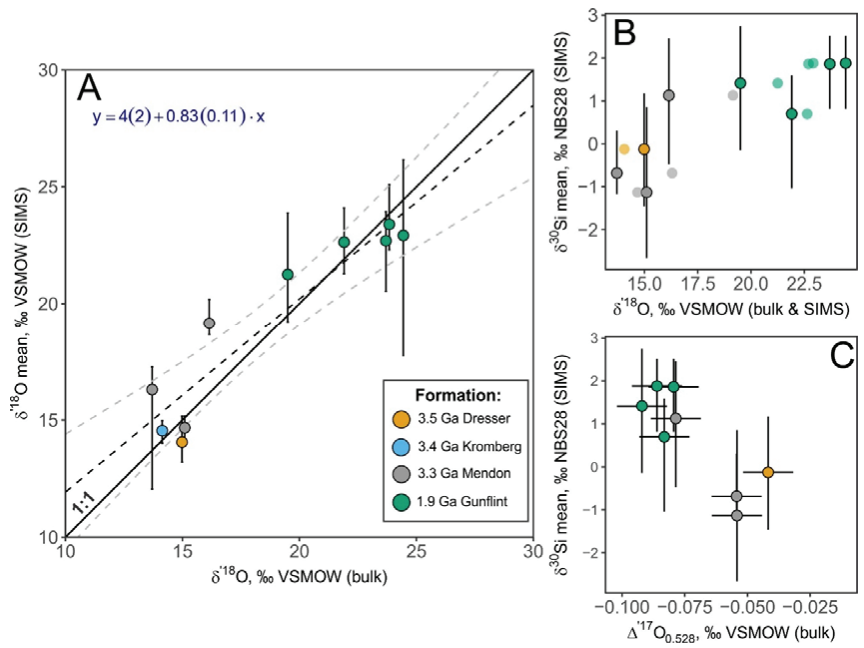

Figure 8. The comparison of the data measured in bulk by laser fluorination GS-IRMS in this study versus the average values of each samples measured by SIMS. The vertical error bar in each plot represents the total range of values measured by SIMS (e.g., length $=\delta^{\prime 18} \mathrm{O}_{\max }-\delta^{\prime 18} \mathrm{O}_{\min }$ ). Panel A shows oxygen isotope composition of cherts measured by two different methods with the least-square regression line and $95 \%$ confidence intervals shown with dashed lines. The equation of such line is displayed in the upper left corner. The black solid line has the slope of 1 and xy-intercepts 0 . The oxygen isotope values versus average $\delta^{30} \mathrm{Si}$ is shown in Panel B. The vertical bars show range of $\delta^{30} \mathrm{Si}$ determined by SIMS. The symbols with black rim are plotted as $\delta^{\prime 18} \mathrm{O}$ values determined in bulk analyses. The symbols without the black rim were plotted using the average $\delta^{\prime 18} \mathrm{O}$ values determined by SIMS. The $\Delta^{\prime 17} \mathrm{O}$ values plotted against $\delta^{30} \mathrm{Si}$ is shown in $\mathbf{C}$. The horizontal error bars in $\mathbf{C}$ are analytical. NEED NEW ORIGINAL 


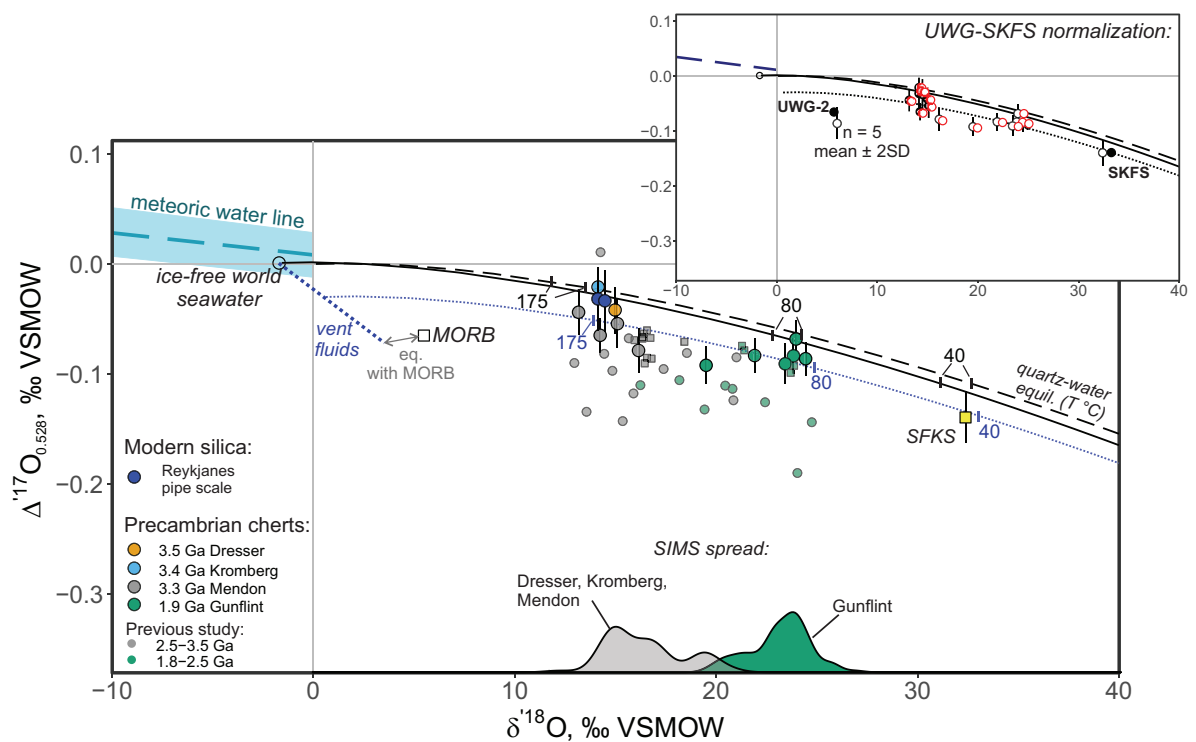

Figure 9. The triple oxygen isotope values of the samples measured in this (large circles) and previous studies. Small circles are cherts from Liljestrand et al. (2020), small squares are values from Hayles et al. (2019). The silica-water equilibria are shown with curved lines projecting from modern ice-free seawater (solid; $\delta^{\prime 18} \mathrm{O}_{\mathrm{sw}}=-1 \%$ ), modern seawater (dashed) and seawater-derived hydrothermal fluids (dotted). The array of hydrothermal vent fluids that approach the composition of fluids in equilibrium with mid-ocean ridge basalts (MORB) is shown with the thick blue dotted line. The meteoric water line is shown based on the compilation of published data (see Sharp et al. 2018). The spread of SIMS values in samples measured here is shown at the bottom of the plot with density distributions. The tick marks black points near each other on different curves all correspond to the same temperatures of silica-water equilibrium at 40, 80 and $175^{\circ} \mathrm{C}$. All of the data shown is calibrated to UWG-2 standard. Only samples containing $>80 \mathrm{wt} \% \mathrm{SiO}_{2}$ are shown for cherts from Liljestrand et al. (2020). The inset in the upper right corner shows our data normalized using two-point calibration using UWG-2 and SKFS standards (Miller et al. 2020; updated values in Sharp and Wosbrock 2020, this volume) demonstrating the negligible effect of scale compression issues. The red points depict 'stretched' values, while black points are normalized using the single-point normalization (same as in the large plot).

distinctly higher $\delta^{\prime 18} \mathrm{O}$ values ranging between 19 and $25 \%$. Their $\Delta^{\prime 17} \mathrm{O}$ values are varying within $-0.08 \pm 0.01 \%$ o, significantly lower than that of the Mendon and Dresser formations. The Reykjanes geothermal scale has $\delta^{\prime 18} \mathrm{O}$ between +14.2 and $+14.6 \%$, accompanied by $\Delta^{\prime 17} \mathrm{O}$ of $-0.03 \%$. The results of triple oxygen isotope analyses are reported in Supplementary Table 1.

The new SIMS values are reported for 2 samples from the Schreiber Beach and Frustration Bay (Gunflint Formation) and one sample PPRG193 (Kromberg Formation) in Supplementary Table 2. The results of previous investigations by (Marin-Carbonne et al. 2012) are compiled in the Supplementary Table 2 as well. The PPRG193 returned the range of $\delta^{\prime 18} \mathrm{O}$ values between +14.2 and $+15.2 \%$, with the average of $+14.8 \pm 0.3 \%$ o $(n=23)$. The $\delta^{\prime 18} \mathrm{O}$ values range between +18 and $+26 \%$, with the average value of $+23.7 \pm 1.8 \%$ o (mean $\pm \sigma ; n=90)$ for the two Gunflint samples, Schreiber Beach and Frustration Bay. We found that in Schreiber Beach sample the $\delta^{\prime 18} \mathrm{O}$ values vary on the scale of $100-200 \mu \mathrm{m}$ by $8 \%$ (Fig. 4). The megaquartz segregations are particularly low in $\delta^{18} \mathrm{O}$, as low as $18 \%$, while microquartz and chalcedony reach values of $+26 \%$ o. These are shown in Figure 4B. The $\delta^{30} \mathrm{Si}$ in Schreiber Beach varies between +0.8 and +2.5 with the average value of $+1.9 \pm 0.4 \%$ o relative to NBS28. The linear regression (Fig. 8) constructed based on the $\delta^{\prime 18} \mathrm{O}$ bulk vs mean $\delta^{\prime 18} \mathrm{O}$ SIMS values yields a slope of $0.8 \pm 0.1$ and $y$-intercept $4 \pm 2 \%$ (mean $\pm 1 \mathrm{se}$ ). It is worth noting that the previous SIMS measurements 
were specifically designed to preferentially target microcrystalline $\delta^{\prime 18} \mathrm{O}$ quartz resulting in the somewhat higher $\left(1-2 \%\right.$ ) mean $\delta^{18} \mathrm{O}$ values compared to the measurements by bulk laser fluorination (Fig. 8). This suggests that bulk fluorination analyses inevitably contain fragments of altered and recrystallized cherts with $\delta^{\prime 18} \mathrm{O}$ values lower than that of microquartz.

The overall $\delta^{\prime 18} \mathrm{O}$ range of the samples is consistent with the values determined in the previous studies by (Hayles et al. 2019; Liljestrand et al. 2020). However, the $\Delta^{\prime 17} \mathrm{O}$ are mostly slightly elevated compared to previous analyses of triple oxygen isotope values in Archean and early Paleoproterozoic cherts produced by (Liljestrand et al. 2020), but agree better with the values determined by (Hayles et al. 2019). To further improve the comparison, we only plotted samples from Liljestrand et al. (2020) that contain $>80 \% \mathrm{SiO}_{2}$. The previously measured cherts from Hayles et al. (2019) shown in Figure 9 are from the Gunflint Formation and Onverwacht group that makes comparison even more accurate. Further, we attempted to re-normalize the previously published analyses to the single scale defined by UWG-2 (see Figs. 5 and 9). Despite these procedures, we cannot explain these differences in the datasets as purely related to calibration. We thus suggest that these differences in $\Delta^{\prime 17} \mathrm{O}$ measured here and in previous studies are at least partly a result of natural variations between samples. This is suggested by the excellent agreement the samples that come from the same well-preserved Gunflint Formation from this study and from the study of Hayles et al. (2019). The samples from Kromberg Formation reported here and in Liljestrand et al. (2020) are more difficult to compare because the formation includes multiple chert layers with variable $\delta^{18} \mathrm{O}$ values (Knauth and Lowe 2003).

Further, we observe a positive correlation between the $\delta^{\prime 18} \mathrm{O}$ values determined in bulk samples and the average of the $\delta^{30} \mathrm{Si}$ values determined by SIMS (Fig. 8). Consequently, the $\Delta^{\prime 17} \mathrm{O}$ value correlate negatively with the $\delta^{30} \mathrm{Si}$. This relationship between the triple oxygen isotope and silicon isotope values (Fig. 8) has not been identified in the previous studies. We suggest that the $\delta^{\prime 18} \mathrm{O}-\Delta^{\prime 17} \mathrm{O}-\delta^{30} \mathrm{Si}$ correlation warrants preservation of distinct difference between samples that, in turn, can be used to decipher the processes recorded in isotope signals.

The $\delta D$ values and water content. The hydrogen isotope values range between -110 and $-60 \%$ with water content between 0.1 and 1.2 wt. \% (Fig. 10). The Mendon and Dresser cherts have the lowest water content, below $0.2 \mathrm{wt}$. $\%$, and the $\delta \mathrm{D}$ ranging from -100 to $-60 \%$. The early Paleoproterozoic Gunflint cherts contain $0.3-1.2$ wt. \% water and $\delta \mathrm{D}$ values between -110 and $-90 \%$. Within each group of samples there is no significant relationship between hydrogen and oxygen isotope ratios or the water content (Fig. 10). We observe no systematic difference between the duplicated analysis of the same chert samples using 3-4 mg or 7-9 mg of analyte. The $\delta \mathrm{D}$ values are variable within $\sim 10 \%$ o between the replicates with exception of two samples, where the difference is close to $20 \%$, likely reflecting natural variability as the analytical precision of this method is $\pm 1-3 \%$ (Fig. 10). The water content of the duplicated measurements varies within $<0.05$ wt. \% with exception of two samples that gave a larger difference in $\delta \mathrm{D}$. In these samples the water content exceeds $0.6 \mathrm{wt}$. $\%$.

\section{Discussion: various origin of Precambrian cherts and record of seawater}

We observe that the cherts from each age group are defined by ranges of values that have distinct differences: Archean samples are generally lower in $\delta^{\prime 18} \mathrm{O}$ and higher in $\Delta^{\prime 17} \mathrm{O}$ compared to the early Paleoproterozoic Gunflint cherts, consistent with the values determined in the previous studies of Precambrian chert (Knauth 2005; Hayles et al. 2019; Liljestrand et al. 2020). We interpret the scatter of $\delta^{\prime 18} \mathrm{O}-\Delta^{\prime 17} \mathrm{O}$ values registered within each formation as the result of precipitation of silica from different sources of fluids during: I) seafloor deposition and seafloor-diagenesis; II) later interaction with fluids and recrystallization during burial metamorphism. We consider marine pore fluids or hydrothermal vent fluids as the possible primary sources of silica attributing them to processes in category I, while fluids of category II would those derived from meteoric sources or crustal/basinal fluids. 

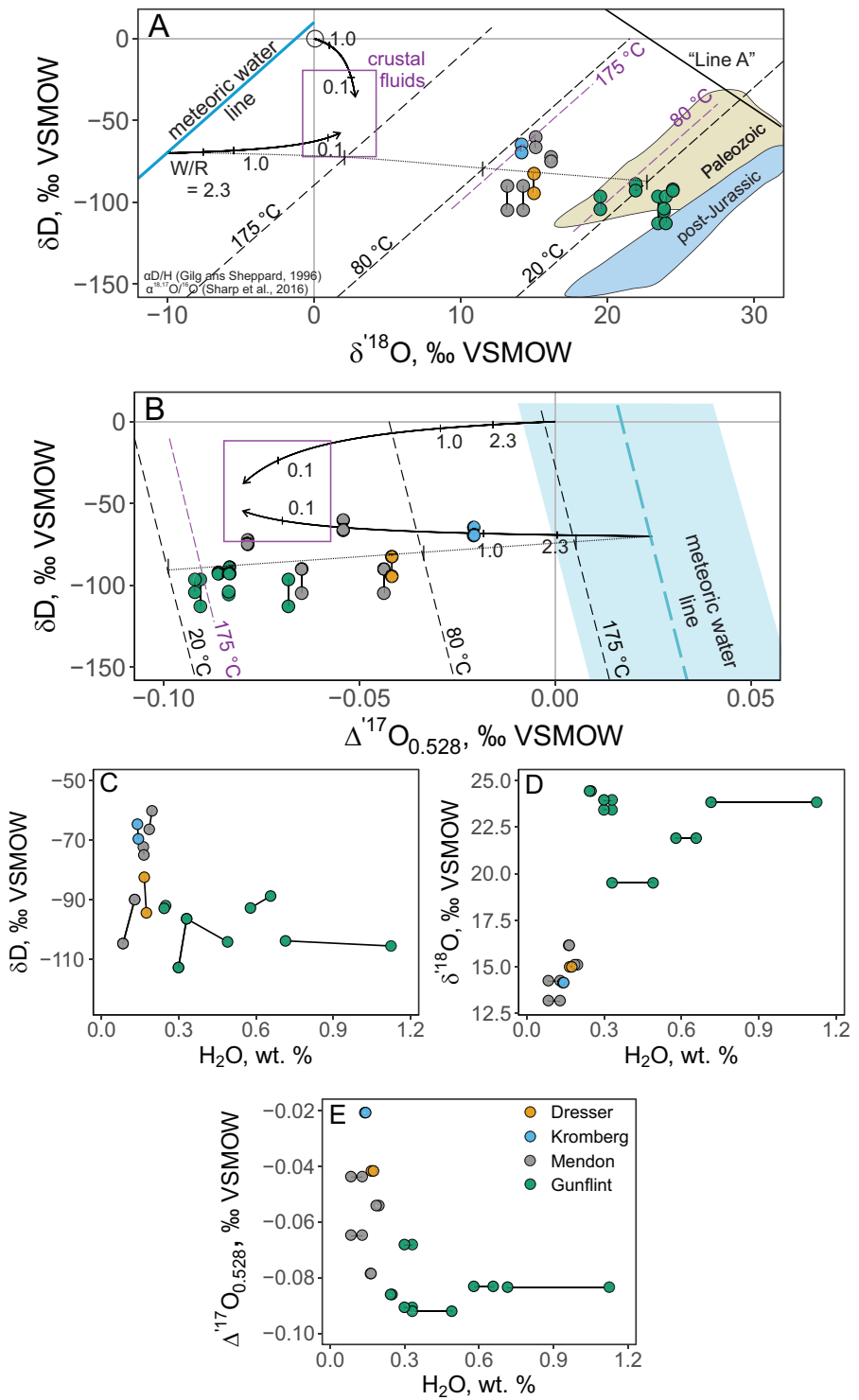

Figure 10. The hydrogen isotope data plotted against the triple oxygen isotope values. The $\delta \mathrm{D}-\delta^{\prime 18} \mathrm{O}$ diagram (A) shows the composition of cherts from Dresser, Kromberg, Mendon and Gunflint Formations plotting in the restricted range of values. The field of Paleozoic cherts is from (Knauth and Epstein 1976). The meteoric water line is shown (Craig 1961) with parallel lines depicting isotope composition of equilibrium silica. Fractionation factors for oxygen (Sharp et al. 2016) and hydrogen (Sheppard and Gilg 1996) are combined to define the isotope value of chert in equilibrium with meteoric waters. Line 'A' from (Knauth and Epstein 1976) depicts cherts in equilibrium with modern ocean. In addition, we show the field of crustal fluids. Such fluids are generated as a result of reaction with crustal rocks. As an example, we show two different meteoric waters reacting with crustal rocks at different water-rock ratios (marked with numbers 0.1 through 2.3). The panel (B) shows the relationship across the hydrogen and triple oxygen isotope ratios. The water content plotted against the isotope parameters $(\mathbf{C}-\mathbf{E})$ display the difference between the Archean (Mendon, Dresser) and the Paleoproterozoic (Gunflint) cherts. The low water content of the Archean cherts and their generally high $\delta \mathrm{D}$ values are clearly different from the more water-rich samples of the Gunflint formation. There is no correlation observed between water content and the isotope ratios when individual formations are considered, however. The duplicated measurements of the same sample are shown as connected points. 
Archean cherts: Dresser, Kromberg and Mendon Formations. The SIMS determinations defined the range of heterogeneous $\delta^{18} \mathrm{O}$ values that span between +14 and $+20 \%$ o in our collection of Archean cherts. Among these samples, the $\delta^{30} \mathrm{Si}$ values span between around $-2 \%$ and $+3 \%$ o (Fig. 7) mostly encompassing the values of igneous rocks $(-1 \%$ ), modern seawater (between +1 and $+3 \%$ ), hydrothermal silica deposits (between -3 and $0 \%$ ) and marine abiotic sediments (between 0 and $+2 \%$; see recent compilation in Kleine et al. 2018). In context of Precambrian, the silicon isotope values below $0 \%$ o have been interpreted to reflect the hydrothermal origin of the silica initially precipitated from vent fluids (Van den Boorn et al. 2007, 2010; Marin-Carbonne et al. 2012). Such low $\delta^{30}$ Si compositions are measured in BIFs (between -4 and 0\%; Konhauser et al. 2017). Further, given that $\mathrm{Al}$ and Ti content of measured microquartz samples is quite low (see Fig. 7), we suggest that involvement of silicified material with igneous origin $\delta^{30} \mathrm{Si}=-1 \%$ in our samples is limited. Meanwhile, microquartz with $\delta^{30} \mathrm{Si}$ above $0 \%$ is thought to represent seawater component (Van den Boorn et al. 2010; Stefurak et al. 2015). Although, $\delta^{30} \mathrm{Si}$ within each sample tends to be extremely variable and texturespecific (Stefurak et al. 2015), the average values correlate with the average $\delta^{\prime 18} \mathrm{O}$ values of the same samples (see Figs. 7 and 8). Among the samples from our collection, only one sample (PPRG 200) from Mendon Formation has the average $\delta^{30} \mathrm{Si}$ of above $0 \%$, which could be used as an indication of the highest input of marine signal. The $\delta^{\prime 18} \mathrm{O}$ values determined by SIMS in this sample are also the highest (up to $+20 \%$ ) compared to the other samples. We thus suggest that the triple oxygen isotope values of the samples with the average negative $\delta^{30} \mathrm{Si}$ values and $\delta^{18} \mathrm{O}$ of around $+14 \%$ o can be used to trace the isotope values of seawater-derived vent fluids, while the value of the PPRG 200 should be closest to marine microquartz.

We find that in triple oxygen isotope space (Fig. 11) most samples, even the PPRG200, plot below the equilibrium curve that projects from the ice-free world seawater. Based on the possible fluid sources resulted from seawater-basalt reactions and the Raman-based record of metamorphism, we construct a field of possible equilibrium and mixed compositions (Fig. 11). Assuming that the original equilibrium fluids were derived from seawater with $\delta^{\prime 18} \mathrm{O} \pm 2 \%$ o of modern seawater, encompassing hydrothermal vent fluid compositions or ice-free world seawater (Fig. 9), the primary Archean microquartz with low $\delta^{30} \mathrm{Si}$ values is best explained by high-temperature equilibrium fractionation at $150-170^{\circ} \mathrm{C}$. The sample PPRG 200 with high $\delta^{30} \mathrm{Si}$ value seem to be also affected by hydrothermal input too as its $\Delta^{\prime 17} \mathrm{O}$ value is quite low, shifted towards the compositions in equilibrium with vent fluids. Using the Raman-based estimate of the metamorphic overprint of $300-360^{\circ} \mathrm{C}$, the secondary low $\Delta^{\prime 17} \mathrm{O}$ quartz formed in equilibrium with fluids with $\delta^{\prime 18} \mathrm{O}$ of crustal values $\left(+3\right.$ to $+5 \%$ o) and with $\Delta^{\prime 17} \mathrm{O}$ close to $-0.05 \%$. Although quartz did not necessarily recrystallize at the temperature recorded by Raman spectroscopy, we suggest that it formed at relatively high temperature due to presence of fluid inclusions hosted in cherts from Onverwacht group that homogenize at temperatures up to $300^{\circ} \mathrm{C}$ (Marin-Carbonne et al. 2011). In addition, the low temperature quartz is proposed as mixing component reflecting a late diagenetic phase precipitated from evolved crustal fluids at $\sim 80^{\circ} \mathrm{C}$ (such is identified with high $\delta^{18} \mathrm{O}$ values in Stefurak et al. 2015; Cammack et al. 2018).

We suggest that initial precipitation of microquartz might have occurred in equilibrium with vent fluids, or from a mixture of seawater and vent fluid sources. The $\Delta^{\prime 17} \mathrm{O}$ of primary silica deposits would be dependent on temperature and the water-rock ratios during seawaterbasalt reaction. Exchange reactions at low water-rock ratios induce oxygen isotope shifts experienced by vent fluids towards the composition of rocks. In our dataset, a sample from the Kromberg Formation for example, plots on modern seawater equilibrium curve at $150^{\circ} \mathrm{C}$ (Fig. 11), which could be explained by the minimal interaction between seawater and basalts, i.e., high water-rock ratios, resulting in negligible oxygen isotope shifts of vent fluids (e.g., Shanks and Seyfried 1987). Further interaction with crustal and basinal fluids (i.e., those that reacted with crustal rocks during burial and metamorphism) and precipitation of equilibrium 
quartz would also contribute to lowering the bulk $\Delta^{\prime 17} \mathrm{O}$ value. Although there is no unique way to reconstruct the late generation quartz compositions, a combination of mixing arrays such as shown in Fig. 11 might help explaining the low $\Delta^{\prime 17} \mathrm{O}$ signature of many chert samples of the Archean that underwent metamorphism.

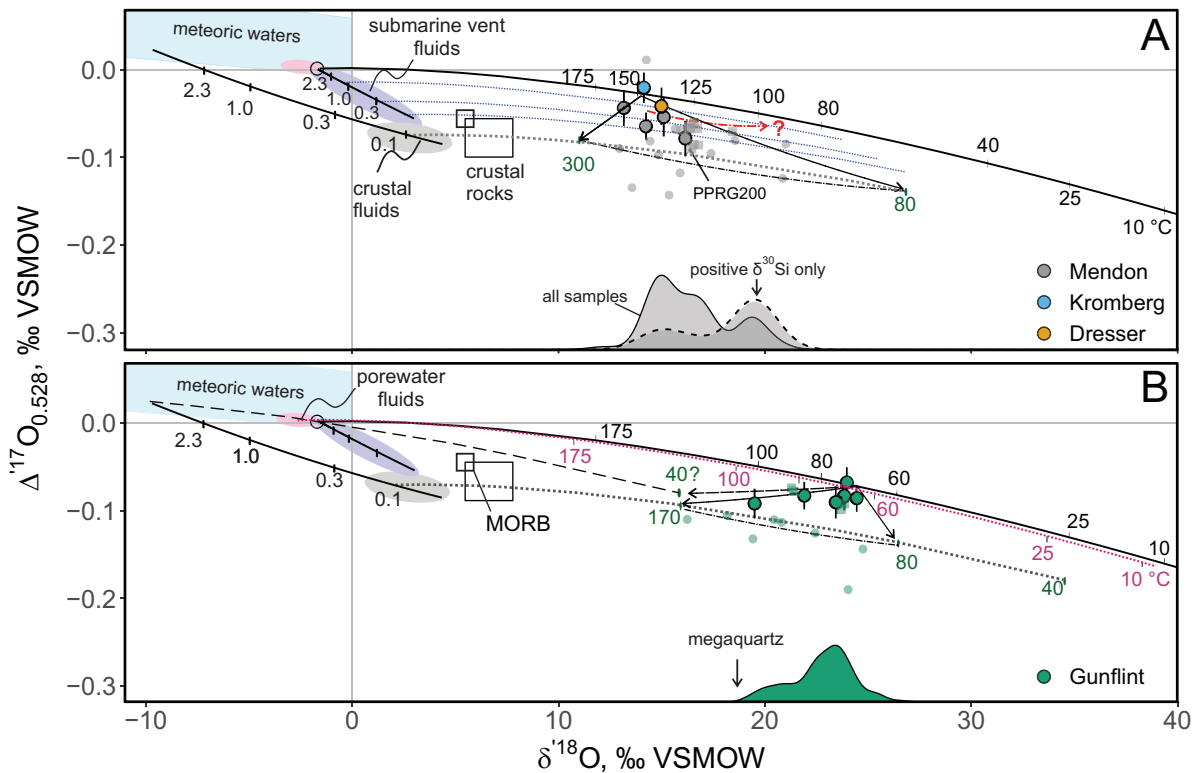

Figure 11. Triple oxygen isotope diagram with Archean (A) and Paleoproterozoic (B) samples divided into separate panels. Based on isotope ratios measured by SIMS, average $\delta^{30} \mathrm{Si}$ values and peak metamorphic temperatures, we attempt to resolve provenance, and distinguish between the early and late generations of quartz (see Discussion). The quartz-water fractionation is shown with the concave-down curves. The solid curve depicts equilibrium with ice-free world seawater. The dashed curves show silica in equilibrium with fluids that underwent reaction either with oceanic crust (blue; submarine vent fluids) or continental crustal rocks (grey; crustal fluids). In the Archean (A), where hydrothermal cycling of seawater might have been important, the silica might have inherited some of the low $\Delta^{\prime 17} \mathrm{O}$ values (blue dotted lines) and low $\delta^{30} \mathrm{Si}$ from vent fluids (shown with the blue field). Those match the $\delta^{\prime 18} \mathrm{O}$ values determined by SIMS in low$\delta^{30} \mathrm{Si}$ samples Further, precipitation of quartz from crustal fluids at $300{ }^{\circ} \mathrm{C}$ during metamorphism is shown with a curve projecting from the respective field. This is the lowest range of metamorphic conditions registered by the Raman spectroscopy and fluid inclusion data (Marin-Carbonne et al. 2011) in our collection of Archean cherts. Mixing with quartz that precipitated at $80^{\circ} \mathrm{C}$ is shown with the concave-up dashed-dotted line, as some cherts contain domains with $\delta^{18} \mathrm{O}$ values between +25 and $+30 \%$, including the cavity-filling quartz from Strelley Pool Formation (Cammack et al. 2018). The red curved arrow and question mark show a possible trajectory taken by cherts that formed as a mixture of seawater and hydrothermally sourced silica. Question mark shows seawater-derived cherts that originally precipitated at $\sim 100^{\circ} \mathrm{C}$ in equilibrium with seawater, as such quartz would correspond to the $\delta^{\prime 18} \mathrm{O}$ values measured by SIMS in a high $\delta^{30} \mathrm{Si}$ sample (PPRG200). In case of the Gunflint Formation (B), several samples plot near the equilibrium fractionation line with seawater at $\sim 70^{\circ} \mathrm{C}$. The marine porewater fluids are shown with the pink field and equilibrium silica is depicted with the pink dotted line. The composition of secondary quartz is constructed based on the $\delta^{\prime 18} \mathrm{O}$ value of $+18 \%$ o measured by SIMS in megaquartz segregations. The equilibrium temperatures of 80 and $170^{\circ} \mathrm{C}$ are picked as possible temperature range of quartz recrystallization in presence of crustal fluids. The temperature of peak metamorphism determined by Raman spectroscopy is between 130 and $170^{\circ} \mathrm{C}$. Alternatively, equilibrium with pristine meteoric water would yield a similar composition of secondary quartz, however at much lower temperatures, around $40^{\circ} \mathrm{C}$ (shown with question mark). These trends are demonstrative of possible origins of low $\Delta^{\prime 17} \mathrm{O}$ values in the studies samples and intend to describe the variability determined by SIMS in this study and by previous determinations within cherts of the same age (Hayles et al. 2019; Liljestrand et al. 2020). 
The early Paleoproterozoic Gunflint chert. Similarly to the procedure outlined above, we use the isotopic values determined by SIMS to distinguish the triple oxygen isotope values of the early from the late generations of silica. In case of Gunflint Formation, the $\mathrm{Al}_{2} \mathrm{O}_{3}$ and $\mathrm{TiO}_{2}$ contents are uniformly low, rarely exceeding 500 and 50 ppm (Fig. 7), respectively, generally reflecting the well-preserved early Paleoproterozoic silica deposits and absence of silicified lithologies in our collection. The cherts of Gunflint Formation used here were collected from Schreiber Beach and Frustration Bat, localities far-removed from the Duluth intrusion and thus, minimally affected by hydrothermal activity and passing all microanalytical criteria presented previously (Marin-Carbonne et al. 2011, 2012). In this case, the earliest generation is best explained by early transformation of the marine silica precursor into microquartz acquiring the high $\delta^{30} \mathrm{Si}$ values between 0 and $+3 \%$. The new SIMS measurements presented here show that the microquartz has values between 23 and $26 \%$, while some (but not all) megaquartz segregations with granoblastic textures have $\delta^{\prime 18} \mathrm{O}$ vales as low as $18 \%$ (Fig. 4). The textural and modeling evidence allowed to distinguish the signal defining the original early diagenetic silica corresponding to the highest $\delta^{\prime 18} \mathrm{O}$ values, that should be close to the mean of the range (Marin-Carbonne et al. 2012).

Using the criteria outlined in (Marin-Carbonne et al. 2012) and our new measurements, we assign the $\delta^{\prime 18} \mathrm{O}$ value of $+24 \%$ as the isotope signature of the early diagenetic silica, i.e., the most primary microquartz. The corresponding $\Delta^{\prime 17} \mathrm{O}$ of this microquartz is $-0.08 \%$ (Fig. 11). The lower range of $\delta^{\prime 18} \mathrm{O}$ values previously measured by SIMS are interpreted as the late stage cycling of fluids during metamorphism. The triple oxygen isotope values corresponding to this generation of quartz are $\delta^{\prime 18} \mathrm{O}=+18 \%$ and were measured directly in this study (see Fig. 4B). One sample ( 5 of 06.28 .84 ) measured for triple oxygen isotope composition yields $\delta^{\prime 18} \mathrm{O}$ of $+19.7 \%$, close to the granoblastic quartz, and $\Delta^{\prime 17} \mathrm{O}=-0.1 \%$. Such composition could be used to derive the general trend induced by alteration during the metamorphic event at the temperature recorded by Raman spectroscopy. Then the Gunflint chert can be explained by primary high $\delta^{\prime 18} \mathrm{O}$ microquartz that precipitated in equilibrium with fluids with $\delta^{\prime 18} \mathrm{O}$ of -4 to $-1 \%$ o, similar to the values of modern sediment-hosted pore fluids (e.g., Aagaard et al. 1989). The corresponding equilibrium temperature recorded by this generation is between 60 and $80^{\circ} \mathrm{C}$, depending on the exact choice of the equilibrium fluid value. The secondary generation of quartz formed via dissolution-reprecipitation at elevated temperatures between 130 and $170^{\circ} \mathrm{C}$ during metamorphism, as constrained by Raman spectroscopy of organic matter (Alleon et al. 2016). The reconstructed equilibrium fluid yields $\delta^{\prime 18} \mathrm{O}$ between +2 and +5 , and $\Delta^{\prime 17} \mathrm{O}$ of around $-0.08 \%$ (Fig. 11).

Triple oxygen isotope signature of the primary fluids. In each chert-bearing formation studied here, the depositional environment is undoubtedly marine, thus we assume that the main reservoirs responsible for precipitation of primary silica and early diagenesis are: I) seawater; II) submarine pore fluids; III) hydrothermal vent fluids (see Fig. 11). The distinction in slopes of these processes in $\delta^{\prime 18} \mathrm{O}--\Delta^{\prime 17} \mathrm{O}$ space is generated via different temperature and different water-rock balance of exchange reactions between seawater and seafloor lithologies. The isotope signatures of the fluid reservoirs are then imprinted in the primary microquartz as shown with their triple oxygen isotopes of modern oceanic quartz, geothermal silica and chert (Fig. 12). As an example of transfer of isotope signature form the seawater-derived vent fluids, we use the Reykjanes scale silica measured in this study, and the previously presented compositions of oceanic quartz and geothermal fluids (Zakharov and Bindeman 2019; Zakharov et al. 2019b). These samples record triple oxygen isotope composition of seawater that underwent isotope exchange with basalt and might serve as a point of comparison for mechanisms of Precambrian silica precipitation (Fig. 13). 
Hydrothermal fluids, Reykjanes silica scale: a comparison with Archean silica. In case of the studied here Archean formations, our interpretation of primary hydrothermal origin of cherts conforms to the previous results based on the field relationships, isotope studies and trace elemental concentrations (de Ronde et al. 1994; Van den Boorn et al. 2007, 2010; Hofmann and Harris 2008; Cammack et al. 2018; Alleon et al. 2019; Lowe et al. 2019). These suggest that many Archean chert deposits, and silicified basalts were produced during reactive circulation of seawater rather than precipitation of silica in deep ocean from cold seawater. However, we should note that the high $\delta^{\prime 18} \mathrm{O}$ cherts (up to $+22 \%$ ) of the Barberton Belt presented by Knauth and Lowe (2003) carry a potential to provide insights into a lower temperature environment, where marine-dominated signal can be better distinguished.

Resulted from reaction with basalt at high temperatures, modern submarine vent fluids are 1-2\%o higher in $\delta^{\prime 18} \mathrm{O}$ than ambient seawater (Shanks 2001) and $0.01-0.02 \%$ lower in $\Delta^{\prime 17} \mathrm{O}$ (Zakharov and Bindeman 2019; Zakharov et al. 2019b). Consequently, we use the geothermal silica scales to demonstrate the possible triple oxygen isotope signature carried by silica-saturated fluids at $\sim 180-190^{\circ} \mathrm{C}$. Our measurements are in close agreement with this temperature. They yield equilibrium temperature of $175^{\circ} \mathrm{C}$ and equilibrium seawater-derived fluids reacted at high water-rock ratio (Fig. 12). These fluids initially resulted from circulation in hot basaltic wall rock at temperature of around $320-350{ }^{\circ} \mathrm{C}$ and subsequently cooled to about $188^{\circ} \mathrm{C}$ (Hardardottir 2011). The cooling is accompanied by boiling and steam-loss when precipitation of amorphous silica occurs along with precipitation of minor carbonate and sulfides on the walls of the geothermal pipes downstream from. For more information on these samples refer to (Hardardottir 2011). Some meteoric water component has been inferred in the Reykjanes system, although the salinity of the fluid is that of seawater (Ólafsson and Riley 1978; Pope et al. 2009). Despite this potential involvement of local precipitation, we do not see a significant enrichment of $\Delta^{\prime 17} \mathrm{O}$ values in our Reykjanes scales (Fig. 9). In general, precipitation mechanism of some of the Precambrian cherts from the Barberton Belt and Pilbara craton that form dikes, occur as fracture-filling aggregates and inter-bedded layers in silicified komatiitic basalts and intruded by numerous magma bodies (e.g., Hofmann and Bolhar 2007; Hofmann and Harris 2008; Lowe et al. 2019) might document a similar style of silica precipitation as recorded by these modern silica scales.

The well fluid compositions of the Reyakjanes geothermal field were measured previously with $\delta^{\prime 18} \mathrm{O}$ between -0.2 and $+1.1 \%$, and $\Delta^{\prime 17} \mathrm{O}$ between -0.025 and $-0.015 \%$ (Zakharov et al. 2019b). Such values are in agreement with the seawater-basalt reaction that took place at water-rock ratios of about 1 (Fig. 12). These might be viewed as the parental fluids for the silica scales as some of the samples were extracted from the same well (RN-9). The reconstructed composition of the earliest generation silica in the Archean Mendon, Kromberg and Dresser Formations are accordingly consistent with precipitation from such vent fluid (Fig. 12). Lowering the water-rock ratio of seawater-basalt reaction would increase the $\delta^{\prime 18} \mathrm{O}$ and lower the $\Delta^{\prime 17} \mathrm{O}$ of chert-forming fluids. Although at much higher temperature $\left(300-350^{\circ} \mathrm{C}\right)$, the effect of low water-rock ratio is depicted with the values of oceanic quartz crystals extracted from the altered oceanic crust drilled at the Oceanic Drilling Project site 504B that were previously analyzed in (Zakharov and Bindeman 2019). With these measurements, the seawater evolution line upon reaction with basalt is clearly constructed and has a slope of around 0.51 in the $\delta^{\prime 17} \mathrm{O}-\delta^{\prime 18} \mathrm{O}$ coordinates, which gives its steep negative slope in the $\delta^{\prime 18} \mathrm{O}-\Delta^{\prime 17} \mathrm{O}$ coordinates (Fig. 12A).

In case of Archean, the reconstructed $\delta^{\prime 18} \mathrm{O}$ values of vent fluids at the Barberton Belt range between +0.9 to $+1.6 \%$, as constrained from the fluid inclusion microthermometry and oxygen isotope measurements of hydrothermal quartz hosted in altered komatiitic rocks spatially associated with the cherts (De Ronde et al. 1997; Farber et al. 2015). The $\Delta^{\prime 17} \mathrm{O}$ value of such fluid would be dependent on the initial value of seawater and the extent of water-rock reaction. 


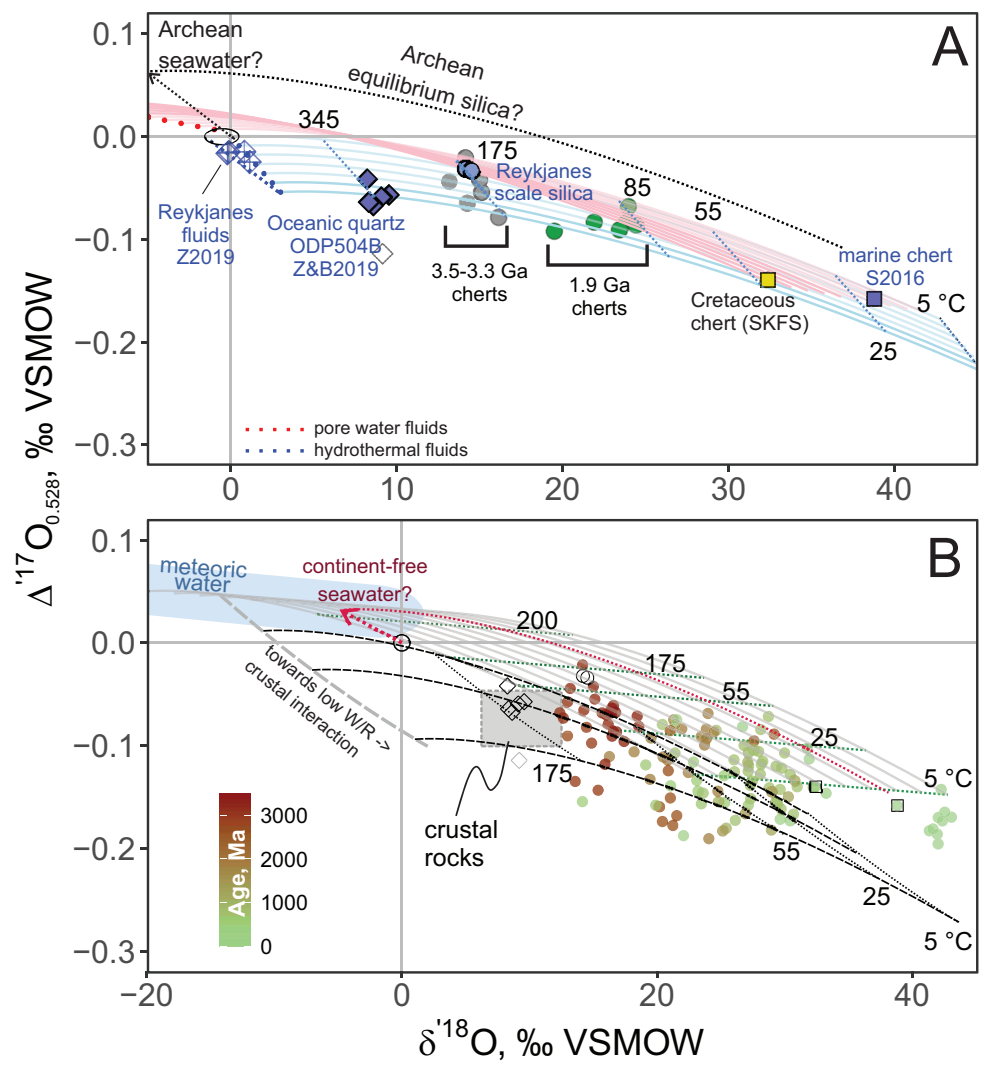

Figure 12. Panel A depicts the systematics of the modern oceanic silica phases. Precipitation of original silica from seawater or seawater-derived fluids (pore and hydrothermal fluids) is shown with pink and blue curves encompassing the temperature range between $5^{\circ} \mathrm{C}$ and infinity (intermediate temperatures are shown), with the $\delta^{\prime 18} \mathrm{O}$ fluid values between +3 and $-4 \%$ of modern seawater value. As an example of hydrothermal vent fluids we show the composition of seawater-dominated well fluids (shown as Z2019; Zakharov et al. 2019) and amorphous silica scale from the pipelines of the Reykjanes system. Further, the oceanic quartz extracted from high-temperature altered oceanic crust (ZB2019; Zakharov and Bindeman 2019) depict equilibrium with evolved seawater-derived fluids. The seawater evolution path induced by hydrothermal circulation is shown with blue dotted lines using modern and ice-free seawater values (collectively shown as oval). Modern marine chert (S2016; Sharp et al. 2016) and Cretaceous chert (SKFS standard measured here) are shown with squares. The sample studied here are shown with shaded circles. The Archean seawater path is shown with the dotted arrow and equilibrium quartz composition is shown with a dotted curve (model after Sengupta and Pack, 2018; see main text below). In Panel B we show the compilation of chert values (Levin et al. 2014; Hayles et al. 2019; Liljestrand et al. 2020; this study) and the modern oceanic silica from panel A (black unfilled shapes). The overarching feature of these datasets is their $\Delta^{\prime 17} \mathrm{O}$ lower than silica in equilibrium with seawater-derived sources (as depicted in A). Secondary quartz in equilibrium with pristine meteoric waters of different composition is shown with an array of grey curves. We also show quartz crystallized from fluids that underwent isotope exchange with crustal rocks at variable water-rock ratios. Precipitation of quartz from pristine or modified meteoric water would require temperature mostly below 55 and $175^{\circ} \mathrm{C}$, respectively, to explain mixing between primary and secondary quartz. In addition, we show the seawater evolution path in absence of continental weathering flux (red arrow; see main text). The composition of such seawater becomes similar to that of meteoric water; however, it does not extend below the value of $\sim-4 \%$ (see Text). 
If the seawater value was 0 or $-1 \%$, then the $\Delta^{\prime 17} \mathrm{O}$ of such fluids would plot along the same trajectory as the modern fluids, without a significant difference. Thus, the positive $\delta^{\prime 18} \mathrm{O}$ values of the fluids would be accompanied by the negative $\Delta^{\prime 17} \mathrm{O}$ values toward the composition of basalt $\left(\delta^{\prime 18} \mathrm{O}=+5.6\right.$ and $\Delta^{\prime 17} \mathrm{O}=-0.06 \%$; Eiler et al. 1997; Cano et al. 2020). The compositions of analyzed here Archean cherts in fact are more consistent with this origin of the fluids, resulted from exchange with basaltic rocks. This trend is consistent with the hypothesis of vent-fluid origin of at least some of the Archean cherts, supported by their low $\delta^{30} \mathrm{Si}$ values. Further, this suggests that the seawater value must have not been significantly different in the Archean from the range between -2 and 0\%o (Holmden and Muehlenbachs 1993; Furnes et al. 2007; Pope et al. 2012; Zakharov and Bindeman 2019). However, it is not possible to reconstruct the ambient seawater temperature directly from these measurements as the vent fluid temperature is not reflective of ambient conditions.

Interstitial pore fluids. Contrary to the Archean counterparts, the Proterozoic cherts of the Gunflint Formation, are found within shallow to deep marine sequences indicating precipitation from the seawater column and with minimal contributing of vent fluid solutions. The high $\delta^{30} \mathrm{Si}$ values measured in post-Archean cherts are also in agreement with limited contribution from basalt-derived hydrothermal silica and primary contribution of diagenetic solutions, initially sourced from seawater dissolved silica (Tatzel et al. 2015). In modern siliceous sediments the crystallization of microquartz is accompanied by interaction with marine pore water fluids. Consequently, we propose that the triple oxygen isotope composition of Gunflint chert sheds light on the composition of sediment-hosted pore water fluids at the temperature of early marine diagenesis. Pore fluids in oceanic crust are routinely measured (e.g., Aagaard et al. 1989; Hesse et al. 2000), yielding $\delta^{\prime 18} \mathrm{O}$ value several\%o lower, between -4 to $-1 \%$ o compared to that of the ambient seawater. Using the corresponding $\Delta^{\prime 17} \mathrm{O}$ shift measured in authigenic minerals (Sengupta and Pack 2018; Bindeman et al. 2019; Bindeman 2020, this volume), we propose that the value of pore fluids must be positive in $\Delta^{\prime 17} \mathrm{O}$ compared to the parental seawater value. Since such fluids are likely representative of the equilibrium fluids for the early diagenetic microquartz that formed within seafloor sediment, the corresponding equilibrium temperature is $60-80^{\circ} \mathrm{C}$ (Figs. 11 and 12). Analogously to the modern pore water fluids retrieved from the siliceous sediments, the signature of the Gunflint Formation chert is best explained by the fluid with $\delta^{\prime 18} \mathrm{O}$ of around $-2 \%$ (Fig. 12).

Secondary fluids: burial metamorphism and post-depositional recrystallization. The textural complexity of silica phases and the several per mil range in $\delta^{\prime 18} \mathrm{O}$ and $\delta^{30} \mathrm{Si}$ values within each sample reflect several stages of interaction with diagenetic and secondary fluids, dissolution-reprecipitation at temperatures different from the initial precipitation. Depending on the history of individual formation, such fluids could originate from local meteorically charged ground waters, and water expelled from hydrous minerals of surrounding lithological units at higher temperature during phase transitions (e.g., illite-smectite or smectite-chlorite transitions; see Bindeman 20XX, this volume). Upon further burial and metamorphism, crustal fluids might become important. Those are dominated by the rock-buffered reactions at high temperature with crustal rocks that on average have $\delta^{\prime 18} \mathrm{O}$ of around $+11 \%$ (Bindeman et al. 2019).

It is evident that Archean cherts studied here were modified by a metamorphic event, which affected all lithologies of the hosting greenstone belts (e.g Xie et al. 1997; Knauth and Lowe 2003). Assuming that quartz recrystallized in the metamorphic conditions (at least $\sim 300^{\circ} \mathrm{C}$ for Mendon and Dresser Formations, as documented by Raman spectroscopy and fluid inclusion studies; Marin-Carbonne et al. 2011), the reconstructed fluids would had to have $\delta^{\prime 18} \mathrm{O}$ values of around $+6 \%$ o to explain the equilibrium secondary silica with low $\Delta^{\prime 17} \mathrm{O}$ value (Fig. 11). These fluids would be similar to those formed at low water-rock ratios and could be calculated in the triple oxygen isotope space given high-temperature fractionation with crustal rocks 
(water-rock ratios below $\sim 0.3$; Fig. 11). The proposed fluids with $\delta^{\prime 18} \mathrm{O}$ around $+5-7 \%$ o would have $\Delta^{\prime 17} \mathrm{O}$ of $-0.1 \%$, which are best explained by rock-buffered reactions that occur in the crust, i.e., crustal fluids (Wilkinson et al. 1995; Baumgartner and Valley 2001; Bindeman 20XX, this volume). Similarly, in case of Gunflint Formation, the late generation silica could have formed at temperatures as high as $170^{\circ} \mathrm{C}$ as indicated by Raman spectroscopy data (Alleon et al. 2016), which yields the corresponding equilibrium fluids with $\delta^{\prime 18} \mathrm{O}$ of +2 to $+5 \%$ and $\Delta^{\prime 17} \mathrm{O}$ of $-0.10 \%$ o. Such fluid signature could be a result of basinal brines (also known as formation waters) contributing to the late diagenetic transformations (e.g., Clayton et al. 1966; Hitchon and Friedman 1969).

In fact, many previous studies explained the low $\delta^{\prime 18} \mathrm{O}$ values of Precambrian cherts by diagenetic interaction with meteoric waters (see Fig. 12). With the triple oxygen isotope approach, it seems difficult to explain all of the low $\Delta^{\prime 17} \mathrm{O}$ values by interaction with pristine meteoric water because in such case the precipitation and dissolution of microquartz had to occur at relatively low temperatures $\left(40-70^{\circ} \mathrm{C}\right.$; Fig. 12) and presumably at high water-rock ratios. The modified crustal fluids would be able to induce the same effect by precipitation of quartz at temperatures between 55 and $175^{\circ} \mathrm{C}$ (see Fig. 12). The sign of change in $\delta^{\prime 18} \mathrm{O}$ from original microquartz to altered chert would depend on its original value and the temperature of interaction with crustal fluids, yet the $\Delta^{\prime 17} \mathrm{O}$ values would change in one direction, negatively (see Fig. 12). Further evidence for interaction between such fluids and sedimentary silica has been documented using in situ SIMS analysis of quartz overgrowth formed in sandstones that experienced several kilometers of burial depth (Williams et al. 1997; Pollington et al. 2011). We are familiar with another example, where crustal fluids brought a significant increase to the $\delta^{18} \mathrm{O}$ of metamorphosed lithologies. The early Paleoproterozoic Scourie dikes of NW Scotland with low $\delta^{18} \mathrm{O}$ magmatic values spanning between -2 to $+2 \%$ oxperienced recrystallization in presence of crustal fluids near shear zones metamorphosed terrains. The attendant increase in the $\delta^{18} \mathrm{O}$ bulk value is 4-5\% (Cartwright and Valley 1992; Zakharov et al. 2019a). Unlike cherts, these rocks are composed of multiple minerals, thus making identification of preserved and metamorphosed precursor more manageable. While direct measurements of basinal and crustal fluids for triple oxygen isotope have not been reported yet, their $\Delta^{\prime 17} \mathrm{O}$ must be low due to exchange with rocks that are isotopically distinct from the surface sources of fluids (Fig. 12). Due to high-temperature fractionation at several kilometers burial depth, the crustal fluid $\Delta^{\prime 17} \mathrm{O}$ would be governed by that of rocks, between -0.06 and $-0.1 \%$ o, spanning between the mantle-derived and metamorphic rocks (see Bindeman 20XX, this volume).

Water content and cherts' hydrogen isotope composition. Measured hydrogen isotope compositions of cherts give us an opportunity to cross-validate the model of origin of secondary quartz, since the bulk $\delta \mathrm{D}$ values of chert are more sensitive to involvement of meteoric water (Fig. 10). This is confirmed by homogeneous $\delta \mathrm{D}$ values measured from multiple chunks of the same samples that only vary about $\pm 10 \%$ on average. The generally low $\delta \mathrm{D}$ values between, -110 and $-60 \%$, likely point towards involvement of meteorically derived fluid (Fig. 10). Even if we assume that water is held by phases with large $\mathrm{H}_{2} \mathrm{O}-\mathrm{OH}$ fractionations defined by low temperature equilibrium (Sheppard and Gilg 1996), we still expect that the low $\delta \mathrm{D}$ values of cherts trace involvement of meteoric waters. Alteration of $\delta \mathrm{D}$ value of chert could also readily occur under ambient temperature due to low hydrogen content and small grain size of microquartz. Even Jurassic and Cretaceous cherts exhibit very low and variable $\delta \mathrm{D}$ compositions owing to low-temperature exchange with local precipitation (Fig. 10; Knauth and Epstein 1976). Moreover, presence of organic material with low $\delta \mathrm{D}$ values in the cherts probably influenced the measured values. For example, the reported total organic carbon in Dresser Formation varies on the order of $0.1 \%$ (Ueno et al. 2004), and would be higher for the well-preserved Gunflint Formation. The weakly bonded hydrogen would have been a subject to modification due to thermal maturation of organic molecules and devolatilization, favoring heavy (high $\delta \mathrm{D}) \mathrm{H}_{2} \mathrm{O}$ loss. 


\section{Triple oxygen isotope evolution of seawater}

Both interstitial pore fluids and vent fluids are considered here as possible sources of equilibrium fluids during the transformation of amorphous silica into microquartz. Such fluids originate from interaction between pristine seawater and oceanic crust and sediments; however, their isotope compositions are directly related to the primary seawater signature. We can first consider the secular evolution of seawater composition in terms of dominant processes that control the isotope ratios of the terrestrial hydrosphere (Fig. 13). The contributions from high-temperature alteration of oceanic crust and from low-temperature weathering reactions provide the two largest volumes of exchanged oxygen delivered into the oceans. The effect produced by each process has been considered in numerous previous publications (Muehlenbachs and Clayton 1972; Holland 1984; Muehlenbachs 1998; Kasting et al. 2006; Kanzaki 2020), including those focused on the triple oxygen isotope ratios (Sengupta and Pack 2018; Bindeman 2020, this volume; Wostbrock and Sharp 2020, this volume). The dominant amount of exchanged oxygen is provided by high-temperature reaction between seawater and oceanic crust at mid-ocean ridges that exerts positive shifts in $\delta^{\prime 18} \mathrm{O}$ and negative in $\Delta^{\prime 17} \mathrm{O}$, close to $+1.5 \%$ ond $-0.03 \%$, respectively (Fig. 13). These isotope shifts are clearly detected by the previously measured $\delta^{18} \mathrm{O}$ values of altered oceanic crust (Alt et al. 1986, 1996; Alt and Teagle 2000; Alt and Bach 2006) and hydrothermal fluids (Shanks and Seyfried 1987; Bach and Humphris 1999; Shanks 2001). These measurements show that the oceanic crust is lower in ${ }^{18} \mathrm{O} /{ }^{16} \mathrm{O}$ than pristine unaltered MORB, while vent fluids are higher compared to ambient seawater. They evolve along similar trajectories in $\delta^{\prime 18} \mathrm{O}-\Delta^{\prime 17} \mathrm{O}$ space but with opposite sign.

Next are the weathering reactions that provide less voluminous, but significant amount of exchanged oxygen. Traced by isotope measurements of weathering products such as submarine clays and terrigenous sediments (Bindeman et al. 2018, 2019; Sengupta and Pack 2018), the collective input of weathering is characterized by the values $-3 \%$ in $\delta^{\prime 18} \mathrm{O}$ and $+0.040 \%$ in $\Delta^{\prime 17} \mathrm{O}$ compared to the values of contemporaneous hydrosphere. These are average values for the combined submarine and terrestrial weathering processes, with the difference shown in Fig. 13. Most importantly, these contributions deliver fluids that are shifted in opposite direction compared to the fluids derived from alteration of oceanic crust. In modern-day oceans, these processes balance seawater at its modern value of around $0 \%$ (Fig. 13). The relative contributions of these fluxes through time is still poorly understood, especially regarding the off-axis alteration of oceanic crust, and may undergo revisions in the near future. We currently adopt the flux figures of Muehlenbachs 1998.

The isotope contribution of other processes such as cycling of water through the mantle wedge at subduction zones, growth of continental crust and increasing proportion of exposed sedimentary blanket complete the isotope budget of terrestrial hydrosphere, however the volume of exchanged oxygen produced by these processes is small, less than $10 \%$, compared to the effect of seawater-basalt reaction and weathering (Muehlenbachs 1998). Moreover the isotope effects produced by these process is difficult to quantify by direct measurements. Given that about $3 \mathrm{~km}^{2}$ of oceanic floor is being produced each year that subsequently undergoes high-temperature alteration at depths between 1 and $3 \mathrm{~km}$ (Alt and Teagle 2000), the seawater-basalt reaction provides the dominant flux of exchanged oxygen into the terrestrial hydrosphere, accounting for $60 \%$ when considered against the contribution from weathering. That is $1.8 \cdot 10^{16} \mathrm{~g} /$ year of exchanged oxygen produced by hydrothermal alteration of oceanic crust (Muehlenbachs 1998). Combined estimated flux of weathering in submarine and terrestrial settings equates to $1.2 \cdot 10^{16} \mathrm{~g} /$ year as estimated from the thickness of lowtemperature altered crust and suspended load of clay fraction carried by rivers (Holland 1984; Muehlenbachs 1998). Even in modern world, these figures are subject to uncertainties due to our inability to directly estimate how much material actually undergoes isotope exchange. It is further complicated by the presence of diverse lithologies of the exposed continental crust 


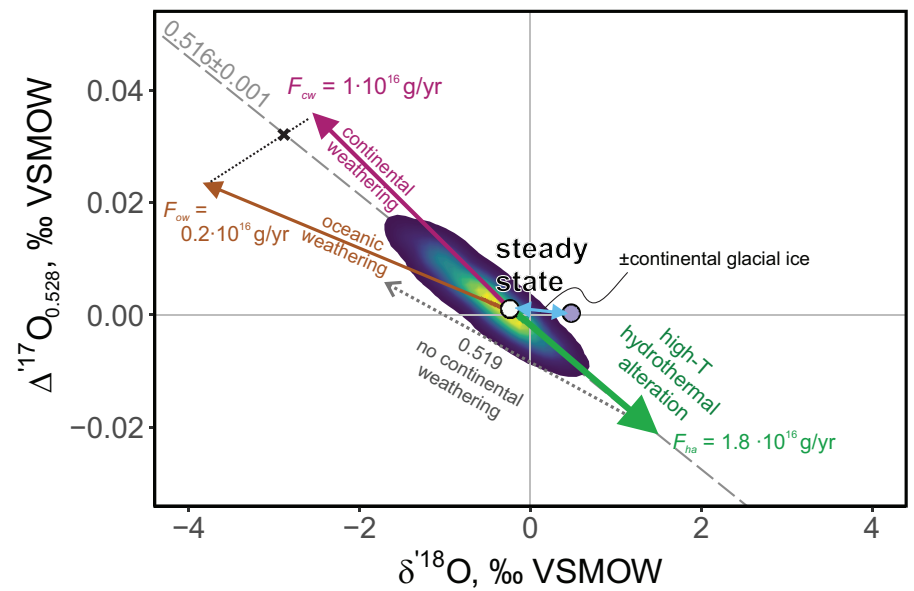

Figure 13. Isotope effect and fluxes $(\mathrm{g} / \mathrm{yr})$ of main contributions to the isotope budget of terrestrial hydrosphere visualized in the triple oxygen isotope coordinates. The high temperature alteration of oceanic crust $\left(F_{h a}\right)$ represents the largest flux of exchanged oxygen into the oceans (flux figures from Muehlenbachs 1998). The slope of isotope exchange produced by hydrothermal input is constrained based on previous studies of hydrothermal fluids and epidotes (Zakharov et al. 2019b). The values of exchanged water produced by oceanic and continental weathering ( $F_{\text {ow }}$ and $F_{\text {ca }}$, respectively) are based on the previous measurements of weathered products (Sengupta and Pack 2018; Bindeman et al. 2019). The relative proportion of the two weathering fluxes in the modern mass-balance model is shown with the cross on the dotted line. The effect of converting $10 \%$ of the hydrosphere into continental glacial ice is shown with the double-sided arrow yielding the seawater $\delta^{\prime 18} \mathrm{O}$ value of about $+0.5 \%$. A potential explanation for the moderately low ${ }^{18} \mathrm{O} /{ }^{16} \mathrm{O}$ ratio of Archean seawater (e.g., Bindeman 2020, this volume) is possible by enhanced weathering fluxes and/or lower hydrothermal activity. The outputs of the Monte-Carlo simulation of the steady state solution with variable fluxes are shown with the concentrically colored-coded density distribution. The warmer colors represent higher relative density distribution. The continental weathering and hydrothermal inputs were varied between 50 and $150 \%$ of their modern-day values, while oceanic weathering was varied between 50 and $300 \%$. The outputs of the simulation form an array with the slope of $0.516 \pm 0.001$ in $\delta^{\prime 17} \mathrm{O}$ $-\delta^{\prime 18} \mathrm{O}$ coordinates. If all continental weathering is suppressed $(0 \mathrm{~g} / \mathrm{yr})$, the values of seawater will vary along a slope of 0.519 (shown with dashed arrow).

that contain already-weathered material that is in isotopic equilibrium with the weathering fluids. As for the Precambrian world, the spreading rates are not known, while contributions from weathering might have been enhanced by $\mathrm{CO}_{2}$ rich atmospheres. However, the enhanced weathering would be counter-balanced by limited subaerial exposure of the Archean continental land (Flament et al. 2013; Bindeman et al. 2018). Consequently, it is difficult to imagine that the weathering flux of exchanged oxygen was completely overwhelming relative to the hydrothermal input in the early Precambrian causing the dramatically lower ${ }^{18} \mathrm{O} /{ }^{16} \mathrm{O}$ ratios of seawater. A potential solution is offered by a hypothesis in which Archean mid-ocean ridges were exposed above seawater, providing a significantly higher proportion of low-temperature interaction between seawater and ocean floor (Walker and Lohmann 1989).

Nonetheless, we can operate with these simple estimates to reproduce the array of possible compositions of ancient seawater, in a manner similar to the study (Sengupta and Pack 2018). In this simplistic approach, we consider that the ratio of fluxes produced by hydrothermal to weathering processes is what exerts the main control on the isotope composition of seawater. The budget that is dominated by hydrothermal contribution would produce the seawater that is positive in $\delta^{\prime 18} \mathrm{O}$ and negative $\Delta^{\prime 17} \mathrm{O}$, i.e., shifted towards composition of fluids in equilibrium with mid-ocean ridge basalts. In other scenario, where weathering contributions exceed their modern proportion, the isotope ratio of seawater would evolve along a steep slope in $\delta^{\prime 18} \mathrm{O}$ $-\Delta^{\prime 17} \mathrm{O}$ coordinates (Fig. 13; note that the corresponding slope is gentle in $\delta^{\prime 17} \mathrm{O}-\delta^{\prime 18} \mathrm{O}$ 
coordinates). The change in isotope composition of seawater governed by these contributions is described as the sum of flux figures $\left(F_{i}\right)$ multiplied by the respective isotope effects $\left(\Delta \delta^{18 / 17} \mathrm{O}_{i}\right)$ exerted by the respective processes:

$$
\frac{\mathrm{d}\left(\delta^{18 / 17} \mathrm{O}_{\mathrm{sw}}\right)}{\mathrm{d} t}=\left(\frac{\sum_{i} F_{i} \cdot \Delta \delta^{18 / 17} \mathrm{O}_{i}}{m_{\mathrm{O}}}\right)
$$

where $\delta^{18} /{ }^{17} \mathrm{O}_{\text {hyd }}$ and $m_{\mathrm{O}}$ are the isotope value and mass of oxygen contained in the hydrosphere, which is essentially seawater and continental glacial ice. The stead state is reached after about $150 \mathrm{Myr}$ with the values of seawater being $\delta^{\prime 18} \mathrm{O}=-0.2 \%$ and $\Delta^{\prime 17} \mathrm{O}=+0.001 \%$ o. In addition, we performed a Monte-Carlo simulation of this model, where the contributing fluxes were randomly changed anywhere from 50 to $150 \%$ of their modern values using uniform distributions. To make this simulation applicable to the Archean, when the Earth was mostly covered by oceanic crust, we extended the upper variability limit of the oceanic weathering flux to $300 \%$ of its modern value. The locus of steady state solutions is shown in Fig. 13. The direction of changing compositions varies along the slope of $0.516 \pm 0.001$ when expressed in $\delta^{\prime 17} \mathrm{O}-\delta^{\prime 18} \mathrm{O}$ coordinates, similar to what was found by Sengupta and Pack 2018. The $\delta^{\prime 18} \mathrm{O}$ in the output of the simulation varies within -2 to $+1 \%$ and is accompanied by the variation in $\Delta^{\prime 17} \mathrm{O}$ between -0.01 and $+0.02 \%$ (Fig. 13).

Further, if we consider Archean world, where continental exposure might have been minimal (Flament et al. 2013; Bindeman et al. 2018), the fluxes of exchanged oxygen would be merely controlled by equilibrium fractionation between seawater and minerals of basaltic composition at low (off-axis) and high (on-axis) temperature. In such case, seawater would possibly evolve along a simple path between values around -4 and $+1.5 \%$ o with the slope of 0.519 in triple oxygen isotope system as defined by equilibrium fractionation factors (Fig. 13). This limited variability might offer reconciliation for some low ${ }^{18} \mathrm{O} /{ }^{16} \mathrm{O}$ ratios recorded by marine sediments, however not many low $\Delta^{\prime 17} \mathrm{O}$ compositions in the present datasets can be exclusively explained that way (Fig. 12).

This is a characteristic array of seawater values that can be used as a theoretical constraint when considering the triple oxygen isotope evolution of the sedimentary record. That array is shown with the measurements of cherts in Fig. 12. As Sengupta and Pack (2018) rightfully noted, the Precambrian cherts define a range of compositions that cannot reproduced by this array of possible seawater compositions significantly different from modern seawater. However, if the change is small, for example Archean seawater was $-4 \%$, the accompanying shift in $\delta^{\prime 18} \mathrm{O}-\Delta^{\prime 17} \mathrm{O}$ would be similar to that exhibited by the difference between seawater and near-coastal meteoric water (Fig. 12). Our reconstructed primary compositions agree with precipitation from seawater-derived fluids, either vent fluids or marine pore fluids (Fig. 12), and a range of seawater $\delta^{\prime 18} \mathrm{O}$ values between -4 and $+2 \%$ is permitted. Such range of seawater values can offer only a limited range of solutions explaining the carbonate and chert records without invoking higher ocean temperatures $\left(>60^{\circ} \mathrm{C}\right.$; see Fig. 1). However, given that carbonates are even more soluble than quartz, the complexity of diagenetic interactions with fluids must bear a significant impact on the isotope signature of ancient sediments. Moreover, the recent clumped isotope studies of the early Phanerozoic carbonates show that many samples experienced diagenetic alteration (Cummins et al. 2014; Bergmann et al. 2018; Ryb and Eiler 2018), and that the preserved samples do not bear the evidence for exceptionally high oceanic temperatures or for drastically low seawater $\delta^{18}$ O. Similarly to microanalytical investigations of cherts, ancient (post-Cenozoic) carbonates require detailed imaging and trace elemental measurements to define the best preserved domains (Grossman 2012). Bergmann et al. (2018) provided estimates for the Ordovician and Cambrian seawater that range between -2.5 and $+3 \%$ in $\delta^{18} \mathrm{O}$ and the temperatures between 26 and $38^{\circ} \mathrm{C}$. 
However, the recent iron oxide sedimentary record (Galili et al. 2019) presents yet another challenging evidence for the changing of oxygen isotope values of seawater through time, where Cambrian and Precambrian time was characterized by seawater with $\delta^{18} \mathrm{O}$ at least $5 \%$ lower than today, inconsistent with the clumped isotope studies of the early Phanerozoic and with the model presented in Fig. 13. Though iron oxide record has not been explored in detailed by in situ methods, it presents an interesting low-solubility archive of both redox and isotope evolution of terrestrial oceans.

In out suite of samples, the oxygen isotope variations do not require significantly different triple oxygen isotope composition of seawater outside the realm of variable fluxes (Fig. 13). Recrystallization during late diagenesis or metamorphism is likely to disturb the primary signal shifting the triple oxygen isotope composition downward in terms of $\Delta^{\prime 17} \mathrm{O}$, towards the composition of fluids that reacted with crustal rocks.

\section{FUTURE DIRECTION AND CONCLUSIONS}

Fractionation of triple oxygen isotopes between fluids and minerals is a powerful tool recently added to the arsenal of geochemists studying ancient marine record. Theoretically, the $\delta^{\prime 18} \mathrm{O}-\Delta^{\prime 17} \mathrm{O}$ values measured in a pristine microquartz that formed during the last silica transformation within the subseafloor setting should reflect the temperature of the transition and the isotope signature of marine pore water fluids. In the realm of Precambrian chert deposits that underwent multiple episodes of recrystallization induced by diagenesis and metamorphism, the measured $\delta^{\prime 18} \mathrm{O}-\Delta^{\prime 17} \mathrm{O}$ values likely represent a mixture of equilibrium compositions generated asynchronously. This is evident from the SIMS analyses that reveal several-\%o spatial heterogeneity in $\delta^{18} \mathrm{O}$ values within each sample. Sometimes, but not always, the heterogeneities are accompanied by petrographic distinction, e.g., low $\delta^{\prime 18} \mathrm{O}$ veins in high $\delta^{\prime 18} \mathrm{O}$ microquartz. The distance between several-\%o heterogeneities varies on the scale of $10-100 \mu \mathrm{m}$. Consequently, the currently available triple oxygen isotope values of cherts produced by bulk laser fluorination GS-IRMS measurements of $\sim 1 \mathrm{~mm}^{3}$ samples are unlikely to give completely accurate reflection of the original marine pore fluids and equilibrium temperatures. Then the question is, which composition measured by SIMS corresponds to the seafloor-deposited silica that underwent just the early stage of marine diagenesis? Is it possible to reconstruct the $\delta^{\prime 18} \mathrm{O}-\Delta^{\prime 17} \mathrm{O}$ values of this phase? We suggest that the future triple oxygen isotope endeavors should include careful investigation of chert samples with identification of multiple generations of silica. Then, selection of the best-preserved domains could be assessed by trace element measurements, CL-imaging, $\delta^{\prime 18} \mathrm{O}$ and $\delta^{30} \mathrm{Si}$ values measured in situ. Following that, the triple oxygen isotope composition should be measured on these distinct generations of quartz, perhaps using micro-drilling of the samples or partial fluorination. Additional triple oxygen isotope measurements of modern silica sediments carried out across the phase transitions, aided by measurements of local geothermal gradient and pore water fluids (see example in Yanchilina et al. 2020) would greatly assist our understanding of ancient silica cycle.

In this study we examined the triple oxygen isotope compositions of Precambrian cherts accompanied by SIMS measurements. We provided an attempt to disentangle triple oxygen isotope signals of early and late quartz generations in the Precambrian cherts of the wellstudied Dresser, Kromberg, Mendon and Gunflint formations using the SIMS-determined $\delta^{\prime 18} \mathrm{O}$ and $\delta^{30} \mathrm{Si}$ values that span between several\%o within a single sample. Aided by $\mathrm{Al}$ and $\mathrm{Ti}$ concentrations, $\delta^{30} \mathrm{Si}$ values, and Raman spectroscopy, we provide estimates for triple oxygen isotope signature of the early microquartz and late-stage recrystallized quartz on a case-by-case basis. Using the Raman spectroscopy of organic matter hosted in these samples we derived the maximum possible temperature at which recrystallization might have occurred. Further, by using $\delta \mathrm{D}$ values measured in the same samples we tested for involvement of meteoric water during the recrystallization of the cherts. We found that the data set if best explained by the following: 
- The Archean 3.5 Ga Dresser, 3.4 Ga Kromberg and 3.2 Ga Mendon cherts contain lowAl microquartz that was likely the earliest generation of silica precipitated in an environment with mixed hydrothermal and seawater input. The triple oxygen isotope signature of samples with negative $\delta^{30} \mathrm{Si}$ values is consistent with precipitation of microquartz at $150-170^{\circ} \mathrm{C}$. The extrapolation of vent fluids towards pristine seawater does not require a hydrosphere significantly different from the modern-day and icefree world values. This interpretation applies to the samples studied here, which does not mean that all Archean cherts formed from mixed hydrothermal solutions.

- The triple oxygen isotope signature of modern amorphous silica scale precipitated in pipelines of the seawater-dominated hydrothermal system at Reykjanes, Iceland is used here as a possible analogue of Archean chert deposits that resulted from reaction between seawater and basalt. The Reykjanes silica formed at $\sim 188^{\circ} \mathrm{C}$ due to high-temperature reaction between basalt and seawater. The $\delta^{\prime 18} \mathrm{O}-\Delta^{\prime 17} \mathrm{O}$ values of such silica is in good agreement with this temperature and previous measurements of the Reykjanes well fluids. Based on the triple oxygen isotopes, we suggest that at least some of the Archean chert deposits might reflect a similar regime of silica precipitation. Such cherts would have $\delta^{\prime 18} \mathrm{O}-\Delta^{\prime 17} \mathrm{O}$ values defined by hightemperature exchange reaction with basaltic rocks at different water-rock ratios. At decreasing water-rock ratios, the silica acquires $\Delta^{\prime 17} \mathrm{O}$ values lower than that of silica in equilibrium with pristine seawater.

- The Paleoproterozoic Gunflint chert contains high- $\delta^{\prime 18} \mathrm{O}$ generation of microquartz that is thought to originally crystallized from marine siliceous sediment based on trace element concentrations and silicon isotope measurements. We interpret the triple oxygen isotope signature of such microquartz as a record of marine pore fluids. The $\delta^{\prime 18} \mathrm{O}-\Delta^{\prime 17} \mathrm{O}$ of such quartz is consistent with equilibrium temperature of $60-80^{\circ} \mathrm{C}$, given that the pore fluid values had $\delta^{\prime 18} \mathrm{O}$ of around $-2 \%$.

- Triple oxygen isotope values of secondary quartz resulted from dissolution-reprecipitation of original material indicates involvement of crustal fluids, akin to modern basinal brines. The temperature of imposed signature is estimated from Ramanspectroscopy at $330 \pm 30^{\circ} \mathrm{C}$ and $160 \pm 30^{\circ} \mathrm{C}$ at the Archean and Paleoproterozoic formations, respectively. These estimates help to assess the preservation state of original microquartz. They do not necessarily indicate that oxygen isotope exchange occurred at these temperatures, however in case of Onverwacht group cherts, these temperatures are close to the homogenization temperatures measured in chert-hosted fluid inclusions (Marin-Carbonne et al. 2011). These temperatures also allow us to suggest that the fluids altering primary signals might have ranged between +2 to $+5 \%$, and their $\Delta^{\prime 17} \mathrm{O}$ are low, close to $-0.1 \%$ o, characteristic of crustal origin. Such fluids would cause cherts to become low in $\Delta^{\prime 17} \mathrm{O}$, between -0.06 and $-0.1 \%$ o. Such mechanism offers a generalized explanation for some of the low $\Delta^{\prime 17} \mathrm{O}$ cherts present in the global dataset (Fig. 12).

Triple oxygen isotope investigation of Precambrian cherts, even in combination with high-resolution methods demonstrate their polygenic nature and limited utility to directly read isotopic values of the seawater and the Earth's surface temperatures. Despite the complexity of chert deposition and its cycle through diagenetic and metamorphic transformations, the recorded secular isotope trend is still best explained by the temperature control, but not in a straightforward way as a reflection of the ocean temperatures. The high-temperature early diagenetic and hydrothermal processes fueled by circulation of seawater within seafloor sediments can account for the signature of some Archean cherts without the need to invoke a significantly different oxygen isotope value of the terrestrial hydrosphere. Future triple oxygen isotope investigations of cherts should involve samples that underwent careful examination in the context of geological setting, trace elemental and mineralogical composition as well as microscale isotope variations. 


\section{ACKNOWLEDGEMENTS}

We are thankful to Stanley Awramcik, Bill Schopf, François Robert for donating their samples to this study and previous studies, and Mike Hudak for measuring the $\delta \mathrm{D}$ values in cherts. We also thank Vigdís Hardardóttir for granting the samples of Reykjanes silica scales for triple oxygen isotope analyses and Mark Reed for facilitating the access to the samples. JMC and JA thank the European Research Council (ERC) under the European Union's Horizon program (STROMATA, grant agreement 759289). INB and DZ thank the NSF grant EAR \#1833420. We are grateful to the reviewers Daniel Herwartz and Zach Sharp for their input, comments and suggestions that helped to improve the manuscript.

\section{REFERENCES}

Aagaard P, Egeberg PK, Smalley PC (1989) Diagenetic reactions in Leg 104 sediments inferred from isotope and major element chemistry of interstitial waters. Proc Ocean Drill Program Sci Results 104:273-280

Abraham K, Hofmann A, Foley SF, Cardinal D, Harris C, Barth MG, André L (2011) Coupled silicon-oxygen isotope fractionation traces Archaean silicification. Earth Planet Sci Lett 301:222-230

Alexandre A, Basile-Doelsch I, Delhaye T, Borshneck D, Mazur J-C, Reyerson P, Santos GM (2015) New highlights of phytolith structure and occluded carbon location: 3-DX-ray microscopy and NanoSIMS results. Biogeosciences $12: 863-873$

Alleon J, Bernard S, Le Guillou C, Marin-Carbonne J, Pont S, Beyssac O, McKeegan KD, Robert F (2016) Molecular preservation of $1.88 \mathrm{Ga}$ Gunflint organic microfossils as a function of temperature and mineralogy. Nat Commun 7:1-11

Alleon J, Bernard S, Le Guillou C, Beyssac O, Sugitani K, Robert F (2018) Chemical nature of the 3.4 Ga Strelley Pool microfossils. Geochem Perspect Lett 37-42

Alleon J, Flannery DT, Ferralis N, Williford KH, Zhang Y, Schuessler JA, Summons RE (2019) Organo-mineral associations in chert of the $3.5 \mathrm{Ga}$ Mount Ada Basalt raise questions about the origin of organic matter in Paleoarchean hydrothermally influenced sediments. Sci Rep 9:16712

Allwood AC, Walter MR, Kamber BS, Marshall CP, Burch IW (2006) Stromatolite reef from the Early Archaean era of Australia. Nature 441:714-718

Allwood AC, Walter MR, Burch IW, Kamber BS (2007) 3.43 billion-year-old stromatolite reef from the Pilbara Craton of Western Australia: ecosystem-scale insights to early life on Earth. Precambrian Res 158:198-227

Alt JC, Bach W (2006) Oxygen isotope composition of a section of lower oceanic crust, ODPHole 735B. Geochem Geophys Geosyst 7: Q12008

Alt JC, Teagle DAH (2000) Hydrothermal alteration and fluid fluxes in ophiolites and oceanic crust. In Ophiolites and oceanic crust: new insights from field studies and the Ocean Drilling Program. Geological Society of America

Alt JC, Muehlenbachs K, Honnorez J (1986) An oxygen isotopic profile through the upper kilometer of the oceanic crust, DSDPHole 504B. Earth Planet Sci Lett 80:217-229

Alt JC, Kinoshita H, Stokking LB, Michael PJ (Eds.) (1996) Proc Ocean Drill Program Sci Results Vol 148. Ocean Drilling Program

André L, Cardinal D, Alleman LY, Moorbath S (2006) Silicon isotopes in 3.8 Ga West Greenland rocks as clues to the Eoarchaean supracrustal Si cycle. Earth Planet Sci Lett 245:162-173

Appleby SK, Graham CM, Gillespie MR, Hinton RW, Oliver GJH, Eimf (2008) A cryptic record of magma mixing in diorites revealed by high-precision SIMS oxygen isotope analysis of zircons. Earth Planet Sci Lett 269:105-117

Awramik SM, Barghoorn ES (1977) The Gunflint microbiota. Precambrian Res 5:121-142

Bach W, Humphris SE (1999) Relationship between the Sr and O isotope compositions of hydrothermal fluids and the spreading and magma-supply rates at oceanic spreading centers. Geology 27:1067-1070

Barghoorn ES, Tyler SA (1965) Microorganisms from the Gunflint Chert. Science 147:563-577

Baumgartner LP, Valley JW (2001) Stable isotope transport and contact metamorphic fluid flow. Rev Mineral Geochem 43:415-467

Bégué F, Baumgartner LP, Bouvier A-S, Robyr M (2019) Reactive fluid infiltration along fractures: Textural observations coupled to in-situ isotopic analyses. Earth Planet Sci Lett 519:264-273

Behl R, Garrison RE, Iijima I, Abed A, Garrison, R (1994) The origin of chert in the Monterey Formation of California (USA). In Siliceous, phosphatic and glauconitic sediments of the Tertiary and Mesozoic: Proceedings of the 29th International Geological Congress, Part C, p 101-132

Bellucci JJ, Whitehouse MJ, Nemchin AA, Snape JF, Kenny GG, Merle RE, Bland PA, Benedix GK (2020) Tracing martian surface interactions with the triple $\mathrm{O}$ isotope compositions of meteoritic phosphates. Earth Planet Sci Lett 531:115977

Bergmann KD, Finnegan S, Creel R, Eiler JM, Hughes NC, Popov LE, Fischer WW (2018) A paired apatite and calcite clumped isotope thermometry approach to estimating Cambro-Ordovician seawater temperatures and isotopic composition. Geochim Cosmochim Acta 224:18-41 
Berner RA, Kothavala Z (2001) Geocarb III: A revised model of atmospheric $\mathrm{CO}_{2}$ over Phanerozoic Time. Am J Sci 301:182-204

Beyssac O, Goffé B, Chopin C, Rouzaud JN (2002) Raman spectra of carbonaceous material in metasediments: a new geothermometer. J Metamorph Geol 20:859-871

Beyssac O, Bollinger L, Avouac J-P, Goffé B (2004) Thermal metamorphism in the lesser Himalaya of Nepal determined from Raman spectroscopy of carbonaceous material. Earth Planet Sci Lett 225:233-241

Bindeman IN (2020) Triple oxygen isotopes in evolving continental crust, granites, and clastic sediments. Rev Mineral Geochem 86:xxx-Xxx

Bindeman IN, Valley JW (2001) Low- $\delta^{18} \mathrm{O}$ rhyolites from Yellowstone: Magmatic evolution based on analyses of zircons and individual phenocrysts. J Petrol 42:1491-517

Bindeman IN, Fu B, Kita NT, Valley JW (2008) Origin and evolution of silicic magmatism at yellowstone based on ion microprobe analysis of isotopically zoned zircons. J Petrol 49:163-193

Bindeman IN, Bekker A, Zakharov DO (2016) Oxygen isotope perspective on crustal evolution on early Earth: A record of Precambrian shales with emphasis on Paleoproterozoic glaciations and Great Oxygenation Event. Earth Planet Sci Lett 437:101-113

Bindeman IN, Zakharov DO, Palandri J, Greber ND, Dauphas N, Retallack GJ, Hofmann A, Lackey JS, Bekker A (2018) Rapid emergence of subaerial landmasses and onset of a modern hydrologic cycle 2.5 billion years ago. Nature 557:545-548

Bindeman IN, Bayon G, Palandri J (2019) Triple oxygen isotope investigation of fine-grained sediments from major world's rivers: Insights into weathering processes and global fluxes into the hydrosphere. Earth Planet Sci Lett 528:115851

Binet L, Gourier D, Derenne S (2008) Potential of EPR imaging to detect traces of primitive life in sedimentary rocks. Earth Planet Sci Lett 273:359-366

Bonamici CE, Kozdon R, Ushikubo T, Valley JW (2014) Intragrain oxygen isotope zoning in titanite by SIMS: Cooling rates and fluid infiltration along the Carthage-Colton Mylonite Zone, Adirondack Mountains NY, USA. J Metamorp Geol 32:71-92

Bontognali TR, Sessions AL, Allwood AC, Fischer WW, Grotzinger JP, Summons RE, Eiler JM (2012) Sulfur isotopes of organic matter preserved in 3.45-billion-year-old stromatolites reveal microbial metabolism. PNAS 109:15146-15151

Brandriss ME, O’Neil JR, Edlund MB, Stoermer EF (1998) Oxygen isotope fractionation between diatomaceous silica and water. Geochim Cosmochim Acta 62:1119-1125

Brasier MD, Antcliffe J, Saunders M, Wacey D (2015) Changing the picture of Earth's earliest fossils (3.5-1.9 Ga) with new approaches and new discoveries. PNAS 112:4859-4864

Brengman LA, Fedo CM, Whitehouse MJ (2016) Micro-scale silicon isotope heterogeneity observed in hydrothermal quartz precipitates from the $>3.7 \mathrm{Ga}$ Isua Greenstone Belt, SWGreenland. Terra Nova 28:70-75

Broecker WS, Broecker WS (1985) How to Build a Habitable Planet. Eldigio Press Palisades, New York

Buick R, Dunlop JSR (1990) Evaporitic sediments of early Archaean age from the Warrawoona Group, North Pole, Western Australia. Sedimentology 37:247-277

Busigny V, Marin-Carbonne J, Muller E, Cartigny P, Rollion-Bard C, Assayag N, Philippot P (2017) Iron, sulfur isotope constraints on redox conditions associated with the 3.2 Ga barite deposits of the Mapepe Formation (Barberton Greenstone Belt, South Africa). Geochim Cosmochim Acta 210:247-266

Cammack JN, Spicuzza M, Cavosie A, Van Kranendonk M, Hickman A, Kozdon R, Orland I, Kitajima K, Valley J (2018) SIMS microanalysis of the Strelley Pool Formation cherts and the implications for the secular-temporal oxygen-isotope trend of cherts. Precambrian Res 304:125-139

Canfield DE (1998) A new model for Proterozoic ocean chemistry. Nature 396:450-453

Cano EJ, Sharp ZD, Shearer CK (2020) Distinct oxygen isotope compositions of the Earth and Moon. Nat Geosci $13: 270-274$

Cao X, Liu Y (2011) Equilibrium mass-dependent fractionation relationships for triple oxygen isotopes. Geochim Cosmochim Acta 75:7435-7445

Carrigan WJ, Cameron EM (1991) Petrological and stable isotope studies of carbonate and sulfide minerals from the Gunflint Formation, Ontario: evidence for the origin of early Proterozoic iron-formation. Precambrian Res 52:347-380

Cartwright I, Valley JW (1992) Oxygen-isotope geochemistry of the Scourian complex, northwest Scotland. J Geol Soc 149:115-125

Chakrabarti R, Knoll AH, Jacobsen SB, Fischer WW (2012) Si isotope variability in Proterozoic cherts. Geochim Cosmochim Acta 91:187-201

Clayton R, Friedman I, Graf D, Mayeda T, Meents W, Shimp N (1966) The origin of saline formation waters: 1. Isotopic composition. J Geophys Res 71:3869-3882

Cloud PE, Gruner JW, Hagen H (1965) Carbonaceous Rocks of the Soudan Iron Formation (Early Precambrian). Science 148:1713-1716

Craig H (1961) Isotopic variations in meteoric waters. Science 133:1702-1703 
Cummins RC, Finnegan S, Fike DA, Eiler JM, Fischer WW (2014) Carbonate clumped isotope constraints on Silurian ocean temperature and seawater $\delta^{18} \mathrm{O}$. Geochim Cosmochim Acta 140:241-258

Cunningham LC, Page FZ, Simonson BM, Kozdon R, Valley JW (2012) Ion microprobe analyses of $\delta^{18} \mathrm{O}$ in early quartz cements from 1.9 Ga granular iron formations (GIFs): A pilot study. Precambrian Res 214:258-268

Dauphas N, Van Zuilen M, Wadhwa M, Davis AM, Marty B, Janney PE (2004) Clues from Fe isotope variations on the origin of early Archean BIFs from Greenland. Science 306:2077-2080

de Ronde CE, de Wit MJ (1994) Tectonic history of the Barberton greenstone belt, South Africa: 490 million years of Archean crustal evolution. Tectonics 13:983-1005

de Ronde CE, de Wit MJ, Spooner ET (1994) Early Archean (> 3.2 Ga) Fe-oxide-rich, hydrothermal discharge vents in the Barberton greenstone belt, South Africa. Geol Soc Am Bull 106:86-104

De Ronde CEJ, Channer DMD, Faure K, Bray CJ, Spooner ETC (1997) Fluid chemistry of Archean seafloor hydrothermal vents: Implications for the composition of circa 3.2 Ga seawater. Geochim Cosmochim Acta 61:4025-4042

de Vries ST, Nijman W, de Boer PL (2010) Sediment Geol of the Palaeoarchaean Buck Ridge (South Africa), Kittys Gap (Western Australia) volcano-sedimentary complexes. Precambrian Res 183:749-769

de Wit MJ, Hart R, Martin A, Abbott P (1982) Archean abiogenic and probable biogenic structures associated with mineralized hydrothermal vent systems and regional metasomatism, with implications for greenstone belt studies. Econ Geol 77:1783-1802

Degens ET, Epstein S (1964) Oxygen and carbon isotope ratios in coexisting calcites and dolomites from recent and ancient sediments. Geochim Cosmochim Acta 28:23-44

Delarue F, Rouzaud J-N, Derenne S, Bourbin M, Westall F, Kremer B, Sugitani K, Deldicque D, Robert F (2016) The Raman-derived carbonization continuum: A tool to select the best preserved molecular structures in Archean kerogens. Astrobiology 16:407-417

Dodd JP, Sharp ZD, Fawcett PJ, Brearley AJ, McCubbin FM (2012) Rapid post-mortem maturation of diatom silica oxygen isotope values. Geochem Geophys Geosyst 13: Q09014

Dubessy J, Caumon M-C, Rull F (2012) Raman Spectroscopy Applied to Earth Sciences and Cultural Heritage. The Mineralogical Society of Great Britain and Ireland

Eiler JM (2011) Paleoclimate reconstruction using carbonate clumped isotope thermometry. Quat Sci Rev 30:3575-3588

Eiler, John M, Farley KA, Valley JW, Hauri E, Craig H, Hart SR, Stolper EM (1997) Oxygen isotope variations in ocean island basalt phenocrysts. Geochim Cosmochim Acta 61:2281-2293

Eiler, John M, Graham C, Valley JW (1997) SIMS analysis of oxygen isotopes: matrix effects in complex minerals and glasses. Chem Geol 138:221-244

Epstein S, Buchsbaum R, Lowenstam H, Urey HC (1951) Carbonate-water isotopic temperature scale. Geol Soc Am Bull 62:417-426

Farber K, Dziggel A, Meyer FM, Prochaska W, Hofmann A, Harris C (2015) Fluid inclusion analysis of silicified Palaeoarchaean oceanic crust-A record of Archaean seawater? Precambrian Res 266:150-164

Flament N, Coltice N, Rey PF (2013) The evolution of the $87 \mathrm{Sr} / 86 \mathrm{Sr}$ of marine carbonates does not constrain continental growth. Precambrian Res 229:177-188

Flannery DT, Allwood AC, Summons RE, Williford KH, Abbey W, Matys ED, Ferralis N (2018) Spatially-resolved isotopic study of carbon trapped in $3.43 \mathrm{Ga}$ Strelley Pool Formation stromatolites. Geochim Cosmochim Acta 223:21-35

Floran RJ, Papike JJ (1978) Mineralogy and petrology of the Gunflint Iron Formation, Minnesota-Ontario: Correlation of compositional and assemblage variations at low to moderate grade. J Petrol 19:215-288

Folk RL, Weaver CE (1952) A study of the texture and composition of chert. Am J Sci 250:498-510

Fralick P, Davis DW, Kissin SA (2002) The age of the Gunflint Formation, Ontario, Canada: single zircon U-Pb age determinations from reworked volcanic ash. Can J Earth Sci 39:1085-1091

Furnes H (2004) Early Life Recorded in Archean Pillow Lavas. Science 304:578-581

Furnes H, de Wit M, Staudigel H, Rosing M, Muehlenbachs K (2007) A vestige of earth's oldest ophiolite. Science 315:1704-1707

Galili N, Shemesh A, Yam R, Brailovsky I, Sela-Adler M, Schuster EM, Collom C, Bekker A, Planavsky N, Macdonald FA, Préat A (2019) The geologic history of seawater oxygen isotopes from marine iron oxides. Science 365:469-473

Geilert S, Vroon PZ, Roerdink DL, Van Cappellen P, van Bergen MJ (2014) Silicon isotope fractionation during abiotic silica precipitation at low temperatures: Inferences from flow-through experiments. Geochim Cosmochim Acta 142:95-114

Geilert S, Vroon PZ, Keller NS, Gudbrandsson S, Stefánsson A, van Bergen MJ (2015) Silicon isotope fractionation during silica precipitation from hot-spring waters: evidence from the Geysir geothermal field, Iceland. Geochim Cosmochim Acta 164:403-427

Goodwin AM (1956) Facies relations in the Gunflint iron formation [Ontario]. Econ Geol 51:565-595

Grossman EL (2012) Applying oxygen isotope paleothermometry in deep time. Paleontolog Soc Pap 18:39-68

Gurenko AA, Chaussidon M (2002) Oxygen isotope variations in primitive tholeiites of Iceland: evidence from a SIMS study of glass inclusions, olivine phenocrysts and pillow rim glasses. Earth Planet Sci Lett 205:63-79 
Hardardottir V (2011) Metal-rich scales in the Reykjanes geothermal system, SW Iceland: sulfide minerals in a seawater-dominated hydrothermal environment. PhD thesis, University of Ottawa, Canada

Harris AC, White NC, McPhie J, Bull SW, Line MA, Skrzeczynski R, Mernagh TP, Tosdal RM (2009) Early Archean hot springs above epithermal veins, North Pole, Western Australia: New insights from fluid inclusion microanalysis. Econ Geol 104:793-814

Hattori I, Umeda M, Nakagawea T, Yamamoto H (1996) From chalcedonic chert to quartz chert; diagenesis of chert hosted in a Miocene volcanic-sedimentary succession, central Japan. J Sediment Res 66:163-174

Hayles J, Gao C, Cao X, Liu Y, Bao H (2018) Theoretical calibration of the triple oxygen isotope thermometer. Geochim Cosmochim Acta 235:237-245

Hayles JA, Yeung LY, Homann M, Banerjee A, Jiang H, Shen B, Lee C-TA (2019) Three billion year secular evolution of the triple oxygen isotope composition of marine chert. preprint, https://eartharxiv.org/n2p5q/ download?format=pdf

Heck PR, Huberty JM, Kita NT, Ushikubo T, Kozdon R, Valley JW (2011) SIMS analyses of silicon and oxygen isotope ratios for quartz from Archean and Paleoproterozoic banded iron formations. Geochim Cosmochim Acta 75:5879-5891

Hervig RL, Williams P, Thomas RM, Schauer SN, Steele IM (1992) Microanalysis of oxygen isotopes in insulators by secondary ion mass spectrometry. Int J Mass Spectrom Ion Processes 120:45-63

Herwartz D, Pack A, Krylov D, Xiao Y, Muehlenbachs K, Sengupta S, Di Rocco T (2015) Revealing the climate of snowball Earth from $\Delta 17 \mathrm{O}$ systematics of hydrothermal rocks. PNAS 112:5337-5341

Hesse R (1988) Diagenesis\# 13. Origin of chert: diagenesis of biogenic siliceous sediments. Geosci Canada 15 171-192

Hesse R (1989) Silica diagenesis: origin of inorganic and replacement cherts. Earth Sci Rev 26:253-284

Hesse R, Frape SK, Egeberg PK, Matsumoto R (2000) 12. Stable isotope studies (Cl, O, and H) of interstitial waters from site 997, Blake Ridge gas hydrate field, West Atlantic 1. Proc Ocean Drill Program Sci Results 164:129-137

Hickman AH (2008) Regional review of the 3426-3350 Ma Strelley Pool Formation, Pilbara Craton, Western Australia. West Australia Geol Surv Rec 2008:15

Hitchon B, Friedman I (1969) Geochemistry and origin of formation waters in the western Canada sedimentary basin-I. Stable isotopes of hydrogen and oxygen. Geochim Cosmochim Acta 33:1321-1349

Hoffman PF, Kaufman AJ, Halverson GP, Schrag DP (1998) A Neoproterozoic snowball Earth. Science 281:1342-1346

Hofmann A, Bolhar R (2007) Carbonaceous cherts in the Barberton Greenstone Belt and their significance for the study of early life in the Archean record. Astrobiology 7:355-388

Hofmann A, Harris C (2008) Silica alteration zones in the Barberton greenstone belt: A window into subseafloor processes 3.5-3.3 Ga ago. Chem Geol 257:221-239

Holland HD (1984) The Chemical Evolution of the Atmosphere and Oceans. Princeton University Press

Holmden C, Muehlenbachs K (1993) The ${ }^{18} \mathrm{O} /{ }^{16} \mathrm{O}$ ratio of 2-billion-year-old seawater inferred from ancient oceanic crust. Science 259:1733-1736

House CH, Schopf JW, McKeegan KD, Coath CD, Harrison TM, Stetter KO (2000) Carbon isotopic composition of individual Precambrian microfossils. Geology 28:707-710

Hren M, Tice M, Chamberlain C (2009) Oxygen and hydrogen isotope evidence for a temperate climate 3.42 billion years ago. Nature 462:205-208

Hudak MR, Bindeman IN (2020) Solubility, diffusivity, and $\mathrm{O}$ isotope systematics of $\mathrm{H}_{2} \mathrm{O}$ in rhyolitic glass in hydrothermal temperature experiments. Geochim Cosmochim Acta 283:222-242

Hyslop EV, Valley JW, Johnson CM, Beard BL (2008) The effects of metamorphism on O and Fe isotope compositions in the Biwabik Iron Formation, northern Minnesota. Contrib Mineral Petrol 155:313-328

Imbrie J, Hays JD, Martinson DG, McIntyre A, Mix AC, Morley JJ, Pisias NG, Prell WL, Shackleton NJ (1984) The orbital theory of Pleistocene climate: support from a revised chronology of the marine $\delta^{18} \mathrm{O}$ record

Jaffrés JBD, Shields GA, Wallmann K (2007) The oxygen isotope evolution of seawater: A critical review of a longstanding controversy and an improved geological water cycle model for the past 3.4 billion years. Earth Sci Rev 83:83-122

Javaux EJ, Lepot K (2018) The Paleoproterozoic fossil record: implications for the evolution of the biosphere during Earth's middle-age. Earth Sci Rev 176:68-86

Jones DL, Knauth PL (1979) Oxygen isotopic and petrographic evidence relevant to the origin of the Arkansas Novaculite. J Sediment Res 49:581-597

Kanzaki Y (2020) Interpretation of oxygen isotopes in Phanerozoic ophiolites and sedimentary rocks. Geochem Geophys Geosyst 21:e2020GC009000

Karhu J, Epstein S (1986) The implication of the oxygen isotope records in coexisting cherts and phosphates. Geochim Cosmochim Acta 50:1745-1756

Kasting JF (1993) Earth's early atmosphere. Science 259:920-926

Kasting JF, Howard MT, Wallmann K, Veizer J, Shields G, Jaffrés J (2006) Paleoclimates, ocean depth, and the oxygen isotopic composition of seawater. Earth Planet Sci Lett 252:82-93

Kelly JL, Fu B, Kita NT, Valley JW (2007) Optically continuous silcrete quartz cements of the St. Peter Sandstone: High precision oxygen isotope analysis by ion microprobe. Geochim Cosmochim Acta 71:3812-3832 
Kirschvink JL, Gaidos EJ, Bertani LE, Beukes NJ, Gutzmer J, Maepa LN, Steinberger RE (2000) Paleoproterozoic snowball Earth: Extreme climatic and geochemical global change and its biological consequences. PNAS 97:1400-1405

Kita NT, Ushikubo T, Fu B, Valley JW (2009) High precision SIMS oxygen isotope analysis and the effect of sample topography. Chem Geol 264:43-57

Kleine BI, Stefánsson A, Halldórsson SA, Whitehouse MJ, Jónasson K (2018) Silicon and oxygen isotopes unravel quartz formation processes in the Icelandic crust. Geochem Perspect Lett 7:5-11

Knauth P (2005) Temperature and salinity history of the Precambrian ocean: implications for the course of microbial evolution. In: Geobiology: Objectives, Concepts, Perspectives, N Noffke (ed), Elsevier, p 53-69

Knauth PL (1979) A model for the origin of chert in limestone. Geology 7:274-277

Knauth PL (1994) Petrogenesis of chert. Rev Mineral 29:233-256

Knauth PL (2005) Temperature and salinity history of the Precambrian ocean: implications for the course of microbial evolution. Palaeogeogr Palaeoclimatol Palaeoecol 219:53-69

Knauth PL, Epstein S (1975) Hydrogen and oxygen isotope ratios in silica from the JOIDES Deep Sea Drilling Project. Earth Planet Sci Lett 25:1-10

Knauth PL, Epstein S (1976) Hydrogen and oxygen isotope ratios in nodular and bedded cherts. Geochim Cosmochim Acta 40:1095-1108

Knauth PL, Lowe DR (1978) Oxygen isotope geochemistry of cherts from the Onverwacht Group (3.4 billion years), Transvaal, South Africa, with implications for secular variations in the isotopic composition of cherts. Earth Planet Sci Lett 41:209-222

Knauth PL, Lowe DR (2003) High Archean climatic temperature inferred from oxygen isotope geochemistry of cherts in the 3.5 Ga Swaziland Supergroup, South Africa. Geol Soc Am Bull 115:566-580

Knoll AH (1992) The early evolution of eukaryotes: a geological perspective. Science 256:622-627

Kolodny Y, Epstein S (1976) Stable isotope geochemistry of deep sea cherts. Geochim Cosmochim Acta 40:1195-1209

Konhauser KO, Phoenix VR, Bottrell SH, Adams DG, Head IM (2001) Microbial-silica interactions in Icelandic hot spring sinter: possible analogues for some Precambrian siliceous stromatolites. Sedimentology 48:415-433

Konhauser KO, Planavsky NJ, Hardisty DS, Robbins LJ, Warchola TJ, Haugaard R, Lalonde SV, Partin CA, Oonk PB, Tsikos H, Lyons TW (2017) Iron formations: A global record of Neoarchaean to Palaeoproterozoic environmental history. Earth Sci Rev 172:140-177

Kouketsu Y, Mizukami T, Mori H, Endo S, Aoya M, Hara H, Nakamura D, Wallis S (2014) A new approach to develop the Raman carbonaceous material geothermometer for low-grade metamorphism using peak width. Island Arc 23:33-50

Kozdon R, Kelly DC, Valley JW (2018) Diagenetic attenuation of carbon isotope excursion recorded by planktic foraminifers during the Paleocene-Eocene thermal maximum. Paleoceanogr Paleoclimatol 33:367-380

Krot AN, Nagashima K, Ciesla FJ, Meyer BS, Hutcheon ID, Davis AM, Huss GR, Scott ER (2010) Oxygen isotopic composition of the Sun and mean oxygen isotopic composition of the protosolar silicate dust: Evidence from refractory inclusions. Astrophys J 713:1159

Kruener A, Byerly GR, Lowe DR (1991) Chronology of early Archaean granite-greenstone evolution in the Barberton Mountain Land, South Africa, based on precise dating by single zircon evaporation. Earth Planet Sci Lett 103:41-54

Kyser K, Kerrich R (1991) Retrograde exchange of hydrogen isotopes between hydrous minerals and water at low temperatures. In: Stable Isotope Geochemistry: a Tribute to Samuel Epstein, HP Taylor, JR O’Neil; IR Kaplan (eds), Geochem Soc Spec Pub 3, p 409-422

Lahfid A, Beyssac O, Deville E, Negro F, Chopin C, Goffé B (2010) Evolution of the Raman spectrum of carbonaceous material in low-grade metasediments of the Glarus Alps (Switzerland). Terra Nova 22:354-360

Landais A, Barkan E, Luz B (2008) Record of $\delta^{18} \mathrm{O}$ and ${ }^{17} \mathrm{O}$-excess in ice from Vostok Antarctica during the last 150,000 years. Geophys Res Lett 35:L02709

Lanier WP, Lowe DR (1982) Sedimentology of the Middle Marker (3.4 Ga), Onverwacht Group, Transvaal, South Africa. Precambrian Res 18:237-260

Leng MJ, Marshall JD (2004) Palaeoclimate interpretation of stable isotope data from lake sediment archives. Quat Sci Rev 23:811-831

Lepot K, Addad A, Knoll AH, Wang J, Troadec D, Béché A, Javaux EJ (2017) Iron minerals within specific microfossil morphospecies of the $1.88 \mathrm{Ga}$ Gunflint Formation. Nat Commun 8:14890

Levin NE, Raub TD, Dauphas N, Eiler JM (2014) Triple oxygen isotope variations in sedimentary rocks. Geochim Cosmochim Acta 139:173-189

Li S, Levin NE, Chesson LA (2015) Continental scale variation in ${ }^{17} \mathrm{O}$-excess of meteoric waters in the United States. Geochim Cosmochim Acta 164:110-126

Liljestrand FL, Knoll AH, Tosca NJ, Cohen PA, Macdonald FA, Peng Y, Johnston DT (2020) The triple oxygen isotope composition of Precambrian chert. Earth Planet Sci Lett 537:116167

Lisiecki LE, Raymo ME (2005) A Pliocene-Pleistocene stack of 57 globally distributed benthic $\delta^{18} \mathrm{O}$ records. Paleoceanogr 20:PA1003

Lowe DR (1983) Restricted shallow-water sedimentation of Early Archean stromatolitic and evaporitic strata of the Strelley Pool Chert, Pilbara Block, Western Australia. Precambrian Res 19:239-283 
Lowe DR (1994) Accretionary history of the Archean Barberton greenstone belt (3.55-3.22 Ga), southern Africa. Geology 22:1099-1102

Lowe DR, Byerly GR (1999) Stratigraphy of the west-central part of the Barberton Greenstone Belt, South Africa. Geol Soc Am Spec Pap 329:1-36

Lowe DR, Drabon N, Byerly GR (2019) Crustal fracturing, unconformities, and barite deposition, 3.26-3.23 Ga, Barberton Greenstone Belt, South Africa. Precambrian Res 327:34-46

Luz B, Barkan E (2010) Variations of ${ }^{17} \mathrm{O} /{ }^{16} \mathrm{O}$ and ${ }^{18} \mathrm{O} /{ }^{16} \mathrm{O}$ in meteoric waters. Geochim Cosmochim Acta 74:6276-6286

Maliva RG, Siever R (1988) Diagenetic replacement controlled by force of crystallization. Geology 16:688-691

Maliva RG, Knoll AH, Siever R (1989) Secular change in chert distribution: a reflection of evolving biological participation in the silica cycle. Palaios 4:519-532

Maliva RG, Knoll AH, Simonson BM (2005) Secular change in the Precambrian silica cycle: insights from chert petrology. Geol Soc Am Bull 117:835-845

Marin J (2009) Composition isotopique de l'oxygène et du silicium des cherts Précambriens: implications Paléoenvironnementales. PhD Thesis, Institut National Polytechnique de Lorraine

Marin J, Chaussidon M, Robert F (2010) Microscale oxygen isotope variations in 1.9 Ga Gunflint cherts: assessments of diagenesis effects and implications for oceanic paleotemperature reconstructions. Geochim Cosmochim Acta $74: 116-130$

Marin-Carbonne J, Chaussidon M, Boiron M-C, Robert F (2011) A combined in situ oxygen, silicon isotopic, fluid inclusion study of a chert sample from Onverwacht Group (3.35 Ga, South Africa): new constraints on fluid circulation. Chem Geol 286:59-71

Marin-Carbonne J, Chaussidon M, Robert F (2012) Micrometer-scale chemical, isotopic criteria (O and Si) on the origin and history of Precambrian cherts: Implications for paleo-temperature reconstructions. Geochim Cosmochim Acta 92:129-147

Marin-Carbonne J, Faure F, Chaussidon M, Jacob D, Robert F (2013) A petrographic and isotopic criterion of the state of preservation of Precambrian cherts based on the characterization of the quartz veins. Precambrian Res 231:290-300

Marin-Carbonne J, Busigny V, Miot J, Rollion-Bard C, Muller E, Drabon N, Jacob D, Pont S, Robyr M, Bontognali TR (2020) In Situ Fe, S isotope analyses in pyrite from the $3.2 \mathrm{Ga}$ Mendon Formation (Barberton Greenstone Belt, South Africa): Evidence for early microbial iron reduction. Geobiology 18:306-325

Matheney RK, Knauth PL (1993) New isotopic temperature estimates for early silica diagenesis in bedded cherts. Geology 21:519-522

Matsuhisa Y, Goldsmith JR, Clayton RN (1978) Mechanisms of hydrothermal crystallization of quartz at $250^{\circ} \mathrm{C}$ and 15 kbar. Geochim Cosmochim Acta 42:173-182

McCrea JM (1950) On the isotopic chemistry of carbonates and a paleotemperature scale. J Chem Phys 18:849-857

McKeegan KD (1987) Oxygen isotopes in refractory stratospheric dust particles: proof of extraterrestrial origin. Science 237:1468-1471

Miller KG, Kominz MA, Browning JV, Wright JD, Mountain GS, Katz ME, Sugarman PJ, Cramer BS, Christie-Blick N, Pekar SF (2005) The Phanerozoic record of global sea-level change. Science 310:1293-1298

Miller MF, Pack A, Bindeman IN, Greenwood RC (2020) Standardizing the reporting of $\Delta^{17} \mathrm{O}$ data from high precision oxygen triple-isotope ratio measurements of silicate rocks and minerals. Chem Geol 532:119332

Muehlenbachs K (1998) The oxygen isotopic composition of the oceans, sediments and the seafloor. Chem Geol 145:263-273

Muehlenbachs K, Clayton RN (1972) Oxygen isotope studies of fresh and weathered submarine basalts. Can J Earth Sci 9:172-184

Murata KJ, Friedman I, Gleason JD (1977) Oxygen isotope relations between diagenetic silica minerals in Monterey Shale, Temblor Range, California. Am J Sci 277:259-272

Nijman W, Valkering ME (1998) Growth fault control of Early Archaean cherts, barite mounds and chert-barite veins, North Pole Dome, Eastern Pilbara, Western Australia. Precambrian Res 88:25-52

Okamoto G, Okura T, Goto K (1957) Properties of silica in water. Geochim Cosmochim Acta 12:123-132

Ólafsson J, Riley JP (1978) Geochemical studies on the thermal brine from Reykjanes (Iceland). Chem Geol 21:219-237

Pack A, Herwartz D (2014) The triple oxygen isotope composition of the Earth mantle and understanding $\Delta \mathrm{O}^{17}$ variations in terrestrial rocks and minerals. Earth Planet Sci Lett 390:138-145

Paris I, Stanistreet IG, Hughes MJ (1985) Cherts of the Barberton greenstone belt interpreted as products of submarine exhalative activity. J Geol 93:111-129

Passey BH, Ji H (2019) Triple oxygen isotope signatures of evaporation in lake waters and carbonates: A case study from the western United States. Earth Planet Sci Lett 518:1-12

Passey BH, Hu H, Ji H, Montanari S, Li S, Henkes GA, Levin NE (2014) Triple oxygen isotopes in biogenic and sedimentary carbonates. Geochim Cosmochim Acta 141:1-25

Pavlov AA, Kasting JF, Brown LL, Rages KA, Freedman R (2000) Greenhouse warming by $\mathrm{CH}_{4}$ in the atmosphere of early Earth. J Geophys Res: Planets 105:11981-11990

Peck WH, Valley JW, Wilde SA, Graham CM (2001) Oxygen isotope ratios and rare earth elements in 3.3 to $4.4 \mathrm{Ga}$ zircons: Ion microprobe evidence for high $\delta^{18} \mathrm{O}$ continental crust and oceans in the Early Archean. Geochim Cosmochim Acta 65:4215-4229 
Perry EC, Jr, Lefticariu L (2003) Formation and geochemistry of Precambrian cherts. Treatise Geochem 7:407

Perry EC, Jr, Tan F (1972) Significance of oxygen and carbon isotope variations in early Precambrian cherts and carbonate rocks of southern Africa. Geol Soc Am Bull 83:647-664

Peters ST, Szilas K, Sengupta S, Kirkland CL, Garbe-Schönberg D, Pack A (2020a) > 2.7 Ga metamorphic peridotites from southeast Greenland record the oxygen isotope composition of Archean seawater. Earth Planet Sci Lett 544:116331

Peters ST, Alibabaie N, Pack A, McKibbin SJ, Raeisi D, Nayebi N, Torab F, Ireland T, Lehmann B (2020b) Triple oxygen isotope variations in magnetite from iron-oxide deposits, central Iran, record magmatic fluid interaction with evaporite and carbonate host rocks. Geology 48:211-215

Pollington AD, Kozdon R, Valley JW (2011) Evolution of quartz cementation during burial of the Cambrian Mount Simon Sandstone, Illinois Basin: In situ microanalysis of $\delta^{18} \mathrm{O}$. Geology 39:1119-1122

Pope EC, Bird DK, Arnórsson S, Fridriksson T, Elders WA, Fridleifsson GÓ (2009) Isotopic constraints on ice age fluids in active geothermal systems: Reykjanes, Iceland. Geochim Cosmochim Acta 73:4468-4488

Pope EC, Bird DK, Rosing MT (2012) Isotope composition and volume of Earth's early oceans. PNAS 109:4371-4376

Poulton SW, Canfield DE (2011) Ferruginous conditions: a dominant feature of the ocean through Earth's history. Elements 7:107-112

Prokoph A, Shields GA, Veizer J (2008) Compilation and time-series analysis of a marine carbonate $\delta^{18} \mathrm{O}, \delta^{13} \mathrm{C}$, ${ }^{87} \mathrm{Sr} /{ }^{86} \mathrm{Sr}$ and $\delta^{34} \mathrm{~S}$ database through Earth history. Earth Sci Rev 87:113-133

Qi H, Coplen TB, Gehre M, Vennemann TW, Brand WA, Geilmann H, Olack G, Bindeman IN, Palandri J, Huang L, Longstaffe FJ (2017) New biotite and muscovite isotopic reference materials, USGS57 and USGS58, for $\delta^{2} \mathrm{H}$ measurements-A replacement for NBS 30. Chem Geol 467:89-99

Rahl JM, Anderson KM, Brandon MT, Fassoulas C (2005) Raman spectroscopic carbonaceous material thermometry of low-grade metamorphic rocks: Calibration and application to tectonic exhumation in Crete, Greece. Earth Planet Sci Lett 240:339-354

Raymo ME, Ruddiman WF (1992) Tectonic forcing of late Cenozoic climate. Nature 359:117-122

Raymo ME, Kozdon R, Evans D, Lisiecki L, Ford HL (2018) The accuracy of mid-Pliocene $\delta^{18} \mathrm{O}$-based ice volume and sea level reconstructions. Earth Sci Rev 177:291-302

Robert F, Chaussidon M (2006) A palaeotemperature curve for the Precambrian oceans based on silicon isotopes in cherts. Nature 443:969-972

Rollion-Bard C, Blamart D, Cuif J-P, Juillet-Leclerc A (2003) Microanalysis of C and O isotopes of azooxanthellate and zooxanthellate corals by ion microprobe. Coral Reefs 22:405-415

Royer DL, Berner RA, Montañez IP, Tabor NJ, Beerling DJ (2004) $\mathrm{CO}_{2}$ as a primary driver of phanerozoic climate. GSA Today 14:4-10

Rumble D, Miller MF, Franchi IA, Greenwood RC (2007) Oxygen three-isotope fractionation lines in terrestrial silicate minerals: An inter-laboratory comparison of hydrothermal quartz and eclogitic garnet. Geochim Cosmochim Acta 71:3592-3600

Ryb U, Eiler JM (2018) Oxygen isotope composition of the Phanerozoic ocean and a possible solution to the dolomite problem. PNAS 115:6602-6607

Schad M, Halama M, Bishop B, Konhauser KO, Kappler A (2019) Temperature fluctuations in the Archean ocean as trigger for varve-like deposition of iron and silica minerals in banded iron formations. Geochim Cosmochim Acta 265:386-412

Schopf JW, Kudryavtsev AB (2005) Three-dimensional Raman imagery of precambrian microscopic organisms. Geobiology 3:1-12

Schopf JW, Kudryavtsev AB, Agresti DG, Wdowiak TJ, Czaja AD (2002) Laser-Raman imagery of Earth's earliest fossils. Nature 416:73-76

Seitz S, Baumgartner LP, Bouvier A-S, Putlitz B, Vennemann T (2017) Quartz reference materials for oxygen isotope analysis by SIMS. Geostand Geoanal Res 41:69-75

Sengupta S, Pack A (2018) Triple oxygen isotope mass balance for the Earth's oceans with application to Archean cherts. Chem Geol 495:18-26

Sexton PF, Wilson PA, Pearson PN (2006) Microstructural and geochemical perspectives on planktic foraminiferal preservation:"Glassy" versus "Frosty." Geochem Geophys Geosyst 7:Q12P19

Shanks WC (2001) Stable isotopes in seafloor hydrothermal systems: vent fluids, hydrothermal deposits, hydrothermal alteration, and microbial processes. Rev Mineral Geochem 43:469-525

Shanks WC, Seyfried WE (1987) Stable isotope studies of vent fluids and chimney minerals, southern Juan de Fuca Ridge: Sodium metasomatism and seawater sulfate reduction. J Geophys Res: Solid Earth 92:11387-11399

Sharp ZD, Wostbrock JAG (2020) Standardization for the triple oxygen isotope system: waters, silicates, carbonates, air, and sulfates Rev Mineral Geochem 86:xxx-Xxx

Sharp ZD, Atudorei V, Durakiewicz T (2001) A rapid method for determination of hydrogen and oxygen isotope ratios from water and hydrous minerals. Chem Geol 178:197-210

Sharp ZD, Durakiewicz T, Migaszewski ZM, Atudorei VN (2002) Antiphase hydrogen and oxygen isotope periodicity in chert nodules. Geochim Cosmochim Acta 66:2865-2873 
Sharp ZD, Gibbons JA, Maltsev O, Atudorei V, Pack A, Sengupta S, Shock EL, Knauth PL (2016) A calibration of the triple oxygen isotope fractionation in the $\mathrm{SiO}_{2}-\mathrm{H}_{2} \mathrm{O}$ system and applications to natural samples. Geochim Cosmochim Acta 186:105-119

Sharp ZD, Wostbrock JAG, Pack A (2018) Mass-dependent triple oxygen isotope variations in terrestrial materials. Geochem Perspect Lett 7:27-31

Sheppard SMF, Gilg HA (1996) Stable isotope geochemistry of clay minerals: "The story of sloppy, sticky, lumpy, tough" Cairns-Smith (1971). Clay Minerals 31:1-24

Shields G, Veizer J (2002a) Precambrian marine carbonate isotope database: Version 1.1. Geochem Geophys Geosyst 3:1-of

Shields G, Veizer J (2002b) Precambrian marine carbonate isotope database: Version 1.1: Geochem Geophys Geosyst 3:1 of $12-1212$

Siever R (1992) The silica cycle in the Precambrian. Geochim Cosmochim Acta 56:3265-3272

Simonson BM (1987) Early silica cementation and subsequent diagenesis in arenites from four early Proterozoic iron formations of North America. J Sediment Res 57:494-511

Stefurak EJ, Lowe DR, Zentner D, Fischer WW (2014) Primary silica granules-A new mode of Paleoarchean sedimentation. Geology 42:283-286

Stefurak EJ, Fischer WW, Lowe DR (2015) Texture-specific Si isotope variations in Barberton Greenstone Belt cherts record low temperature fractionations in early Archean seawater. Geochim Cosmochim Acta 150:26-52

Strother PK, Tobin K (1987) Observations on the genus huroniospora barghoorn: Implications for paleoecology of the gunflint microbiota. Precambrian Res 36:323-333

Sugitani K, Mimura K, Nagaoka T, Lepot K, Takeuchi M (2013) Microfossil assemblage from the 3400 Ma Strelley Pool Formation in the Pilbara Craton, Western Australia: results form a new locality. Precambrian Res 226:59-74

Surma J, Assonov S, Herwartz D, Voigt C, Staubwasser M (2018) The evolution of ${ }^{17}$ O-excess in surface water of the arid environment during recharge and evaporation. Sci Rep 8:4972

Swann GE, Leng MJ (2009) A review of diatom $\delta^{18} \mathrm{O}$ in palaeoceanography. Quat Sci Rev 28:384-398

Tartèse R, Chaussidon M, Gurenko A, Delarue F, Robert F (2018) Insights into the origin of carbonaceous chondrite organics from their triple oxygen isotope composition. PNAS 115:8535-8540

Tatzel M, von Blanckenburg F, Oelze M, Schuessler JA, Bohrmann G (2015) The silicon isotope record of early silica diagenesis. Earth Planet Sci Lett 428:293-303

Tian C, Wang L, Tian F, Zhao S, Jiao W (2019) Spatial and temporal variations of tap water ${ }^{17}$ O-excess in China. Geochim Cosmochim Acta 260:1-14

Tice MM, Lowe DR (2006) The origin of carbonaceous matter in pre-3.0 Ga greenstone terrains: A review and new evidence from the 3.42 Ga Buck Reef Chert. Earth Sci Rev 76:259-300

Tice MM, Bostick BC, Lowe DR (2004) Thermal history of the 3.5-3.2 Ga Onverwacht and Fig Tree Groups, Barberton greenstone belt, South Africa, inferred by Raman microspectroscopy of carbonaceous material. Geology 32:37-40

Trower EJ, Lowe DR (2016) Sedimentology of the 3.3 Ga upper Mendon Formation, Barberton Greenstone Belt, South Africa. Precambrian Res 281:473-494

Turchyn AV, Alt JC, Brown ST, DePaolo DJ, Coggon RM, Chi G, Bédard JH, Skulski T (2013) Reconstructing the oxygen isotope composition of late Cambrian and Cretaceous hydrothermal vent fluid. Geochim Cosmochim Acta 123:440-458

Tyler SA, Barghoorn ES (1954) Occurrence of Structurally Preserved Plants in Pre-Cambrian Rocks of the Canadian Shield. Science 119:606-608

Ueno Y, Yurimoto H, Yoshioka H, Komiya T, Maruyama S (2002) Ion microprobe analysis of graphite from ca. 3.8 Ga metasediments, Isua supracrustal belt, West Greenland: relationship between metamorphism and carbon isotopic composition. Geochim Cosmochim Acta 66:1257-1268

Ueno Y, Yoshioka H, Maruyama S, Isozaki Y (2004) Carbon isotopes and petrography of kerogens in $~ 3.5-\mathrm{Ga}$ hydrothermal silica dikes in the North Pole area, Western Australia1 1Associate editor: GCody. Geochim Cosmochim Acta 68:573-589

Urey HC, Lowenstam HA, Epstein S, McKinney CR (1951) Measurement of paleotemperatures and temperatures of the Upper Cretaceous of England, Denmark, and the southeastern United States. Geol Soc Am Bull 62:399-416

Valley JW, Graham CM (1996) Ion microprobe analysis of oxygen isotope ratios in quartz from Skye granite: healed micro-cracks, fluid flow, and hydrothermal exchange. Contrib Mineral Petrol 124:225-234

Van den Boorn S, van Bergen MJ, Nijman W, Vroon PZ (2007) Dual role of seawater and hydrothermal fluids in Early Archean chert formation: evidence from silicon isotopes. Geology 35:939-942

Van den Boorn S, Van Bergen M, Vroon P, De Vries S, Nijman W (2010) Silicon isotope and trace element constraints on the origin of 3.5 Ga cherts: implications for Early Archaean marine environments. Geochim Cosmochim Acta 74:1077-1103

Van Kranendonk MJ (2006) Volcanic degassing, hydrothermal circulation and the flourishing of early life on Earth: A review of the evidence from c. 3490-3240 Ma rocks of the Pilbara Supergroup, Pilbara Craton, Western Australia. Earth Sci Rev 74:197-240

Van Kranendonk MJ, Philippot P, Lepot K, Bodorkos S, Pirajno F (2008) Geological setting of Earth's oldest fossils in the ca. 3.5 Ga Dresser Formation, Pilbara Craton, Western Australia. Precambrian Res 167:93-124 
van Zuilen MA, Lepland A, Teranes J, Finarelli J, Wahlen M, Arrhenius G (2003) Graphite and carbonates in the 3.8 Ga old Isua supracrustal belt, southern West Greenland. Precambrian Res 126:331-348

Veizer J, Prokoph A (2015) Temperatures and oxygen isotopic composition of Phanerozoic oceans. Earth Sci Rev 146:92-104

Veizer J, Ala D, Azmy K, Bruckschen P, Buhl D, Bruhn F, Carden GA, Diener A, Ebneth S, Godderis Y, Jasper T (1999) ${ }^{87} \mathrm{Sr}{ }^{86} \mathrm{Sr}, \delta^{13} \mathrm{C}$ and $\delta^{18} \mathrm{O}$ evolution of Phanerozoic seawater. Chem Geol 161:59-88

Wacey D (2010) Stromatolites in the 3400 Ma Strelley Pool Formation, Western Australia: examining biogenicity from the macro-to the nano-scale. Astrobiology 10:381-395

Wacey D, Menon S, Green L, Gerstmann D, Kong C, Mcloughlin N, Saunders M, Brasier M (2012) Taphonomy of very ancient microfossils from the 3400 Ma Strelley Pool Formation and 1900 Ma Gunflint Formation: New insights using a focused ion beam. Precambrian Res 220:234-250

Walker JC, Lohmann KC (1989) Why the oxygen isotopic composition of sea water changes with time. Geophys Res Lett 16:323-326

Watkins JM, Hunt JD (2015) A process-based model for non-equilibrium clumped isotope effects in carbonates. Earth Planet Sci Lett 432:152-165

Wenner DB, Taylor HP (1973) Oxygen and hydrogen isotope studies of the serpentinization of ultramafic rocks in oceanic environments and continental ophiolite complexes. Am J Sci 273:207-239

Whitehouse MJ, Fedo CM (2007) Microscale heterogeneity of Fe isotopes in > $3.71 \mathrm{Ga}$ banded iron formation from the Isua Greenstone Belt, southwest Greenland. Geology 35:719-722

Whitehouse MJ, Nemchin AA (2009) High precision, high accuracy measurement of oxygen isotopes in a large lunar zircon by SIMSChem Geol 261:32-42

Wilkinson JJ, Jenkin GRT, Fallick AE, Foster RP (1995) Oxygen and hydrogen isotopic evolution of Variscan crustal fluids, south Cornwall, UK. Chem Geol 123:239-254

Williams LB, Hervig RL, Bjørlykke K (1997) New evidence for the origin of quartz cements in hydrocarbon reservoirs revealed by oxygen isotope microanalyses. Geochim Cosmochim Acta 61:2529-2538

Williford KH, Ushikubo T, Schopf JW, Lepot K, Kitajima K, Valley JW (2013) Preservation and detection of microstructural and taxonomic correlations in the carbon isotopic compositions of individual Precambrian microfossils. Geochim Cosmochim Acta 104:165-182

Winter BL, Knauth PL (1992) Stable isotope geochemistry of cherts and carbonates from the 2.0 Ga Gunflint Iron Formation: implications for the depositional setting, and the effects of diagenesis and metamorphism. Precambrian Res 59:283-313

Wopenka B, Pasteris JD (1993) Structural characterization of kerogens to granulite-facies graphite: applicability of Raman microprobe spectroscopy. Am Mineral 78:533-557

Wostbrock JAG, Sharp ZD (2020) Triple oxygen isotopes in the silica-water and carbonate-water system. Rev Mineral Geochem 86:xxx-xxx

Wostbrock JAG, Sharp ZD, Sanchez-Yanez C, Reich M, van den Heuvel DB, Benning LG (2018) Calibration and application of silica-water triple oxygen isotope thermometry to geothermal systems in Iceland and Chile. Geochim Cosmochim Acta 234:84-97

Wostbrock JAG, Cano EJ, Sharp ZD (2020) An internally consistent triple oxygen isotope calibration of standards for silicates, carbonates and air relative to VSMOW2 and SLAP2. Chem Geol 533:119432

Xie X, Byerly GR, Ferrell Jr RE (1997) IIb trioctahedral chlorite from the Barberton greenstone belt: crystal structure and rock composition constraints with implications to geothermometry. Contrib Mineral Petrol 126:275-291

Yanchilina AG, Yam R, Kolodny Y, Shemesh A (2020) From diatom opal-A $\delta^{18} \mathrm{O}$ to chert $\delta^{18} \mathrm{O}$ in deep sea sediments. Geochim Cosmochim Acta 268:368-382

Yui T-F, Huang E, Xu J (1996) Raman spectrum of carbonaceous material: A possible metamorphic grade indicator for low-grade metamorphic rocks. J Metamorph Geol 14:115-124

Zakharov DO, Bindeman IN (2019) Triple oxygen and hydrogen isotopic study of hydrothermally altered rocks from the 2.43-2.41 Ga Vetreny belt, Russia: An insight into the early Paleoproterozoic seawater. Geochim Cosmochim Acta 248:185-209

Zakharov DO, Bindeman IN, Slabunov AI, Ovtcharova M, Coble MA, Serebryakov NS, Schaltegger U (2017) Dating the Paleoproterozoic snowball Earth glaciations using contemporaneous subglacial hydrothermal systems. Geology 45:667-670

Zakharov DO, Bindeman IN, Serebryakov NS, Prave AR, Azimov PY, Babarina II (2019a) Low $\delta^{18}$ O rocks in the Belomorian belt, NW Russia, and Scourie dikes, NW Scotland: A record of ancient meteoric water captured by the early Paleoproterozoic global mafic magmatism. Precambrian Res 333:105431

Zakharov DO, Bindeman IN, Tanaka R, Friðleifsson GÓ, Reed MH, Hampton RL (2019b) Triple oxygen isotope systematics as a tracer of fluids in the crust: A study from modern geothermal systems of Iceland. Chemical Geology 530:119312

Zheng Y-F (1993) Calculation of oxygen isotope fractionation in anhydrous silicate minerals. Geochim Cosmochim Acta 57:1079-1091 
Two EIler et al (1997)s. Please dsiambiguate.

One figure was not supplied.

Please supply.

Check red ink 